
De berørte etter 22. juli 

Vidar Enebakk,

Helene Ingierd,

Nils Olav Refsdal

\section{De berørte etter 22. juli}

Forskningsetiske perspektiver 
(c) Vidar Enebakk, Helene Ingierd og Nils Olav Refsdal 2016

Dette verket omfattes av bestemmelsene i Lov om opphavsretten til åndsverk m.v. av 1961. Verket utgis Open Access under betingelsene i Creative Commons-lisensen CC-BY 4.0 (http://creativecommons.org/licenses/ by/4.o/). Denne tillater tredjepart å kopiere, distribuere og spre verket i hvilket som helst medium eller format, og å remixe, endre, og bygge videre på materialet til et hvilket som helst formål, inkludert kommersielle, under betingelse av at korrekt kreditering og en lenke til lisensen er oppgitt, og at man indikerer om endringer er blitt gjort. Tredjepart kan gjøre dette på enhver rimelig måte, men uten at det kan forstås slik at lisensgiver bifaller tredjepart eller tredjeparts bruk av verket.

Kapittel 3, 4, 5, 6 og 7 er fagfellevurdert.

Boken er utgitt i samarbeid med De nasjonale forskningsetiske komiteene og Helsedirektoratet, og er finansiert av Helsedirektoratet.

Typesetting: Datapage India (Pvt.) Ltd.

Cover Design: Kristin Berg Johnsen

Cappelen Damm Akademisk/NOASP

noasp@cappelendamm.no

https://press.nordicopenaccess.no/index.php/noasp 


\section{Innhold}

Innhold.

Introduksjon - forskningsetikk og de

berørte etter 22. juli .

9

Vidar Enebakk, Helene Ingierd og Nils Olav Refsdal

Kapittel 1 Koordinering av forsking på dei berørte

Nils Olav Refsdal

Behovet for samordning. 14

Om koordineringsarbeidet. 15

Diskusjonsforum og arena for brukarmedverknad. 16

Deling av data 17

Eit forskingssystem som er betre rusta ved neste krise 18

Referanser 20

Kapittel 2 Om å delta i forskningen etter 22. juli

Ragnar Eikeland

Kapittel 3 Utøya-studien: Forskningsetiske betraktninger 27

Grete Dyb, Kristin Alve Glad og Gertrud Sofie Hafstad

Innledning. 28

Er det etisk forsvarlig å gjennomføre en slik studie? 29

Hvor lenge bør vi vente? 31

Hvem skal vi invitere med?. 32

Hvordan skal vi samle inn datamaterialet? 33

Hvordan rekruttere og lære opp intervjuerne? 34

Hvordan skal vi ta kontakt med de berørte? 36

Hvor skal intervjuet finne sted? 38

Informert samtykke. 39 
Skal vi bruke lydbånd? .......................................................................... 40

Hvordan kan vi ivareta informantene best mulig? ................................ 40

Udekkede hjelpebehov ....................................................................... 42

Hvordan kan vi ivareta intervjuerne?.................................................. 42

Formidling av resultatene.................................................................... 44

NKVTS' oppdrag og deling av data fra terrorforskningen.................. 45

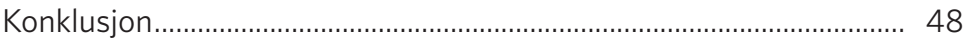

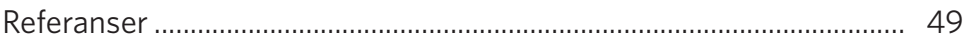

\section{Kapittel 4 Etterlatte og sårbare grupper etter}

traumatiske tap ........................................................................ 52

Kari Dyregrov

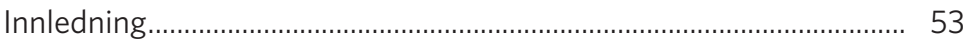

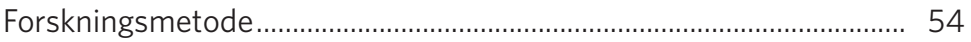

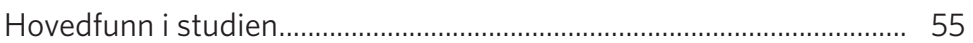

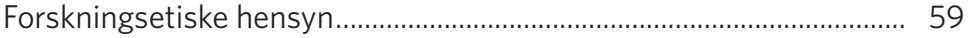

Hvor mye tåler sårbare grupper? ........................................................ 63

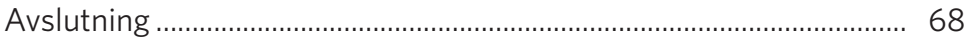

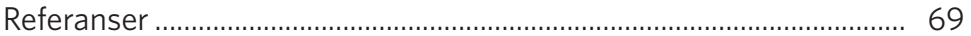

Kapittel 5 Samarbeid, samtykkeerklæring og deling av data ....................................................................................... 73

Annika Melinder og Anne Marita Milde

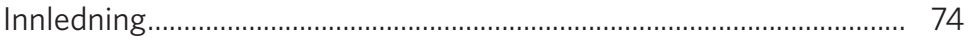

Deling og gjenbruk av data og organisering av samarbeid................. 75

Informert samtykke og innsamling av data...................................... 76

Samarbeid for å bedre deltagerandelen .............................................. 79

Spørsmål knyttet til forfatterskap og kreditering ................................ 81

Oppsummering og forslag til vei videre................................................. 83

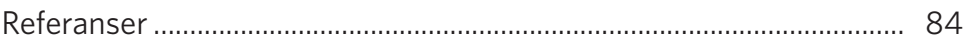

\section{Kapittel 6 Følgeforskning og minneprosesser på}

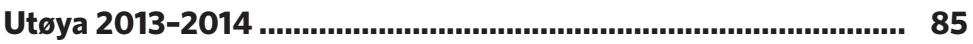

Tor Einar Fagerland

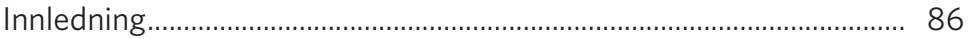

July 22 and the negotiation of memory ............................................ 87

Minnemarkering og lansering av «Nye Utøya» ..................................... 90

Ny start og nytt samarbeidsprosjekt.................................................. 93 
Forskningsetikk og metode - noen refleksjoner ................................. 97

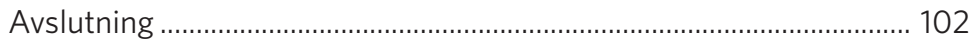

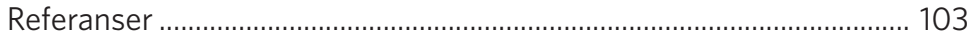

Kapittel 7 Etiske utfordringer i ekstremismeforskningen

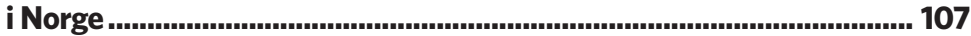

Lars Gule

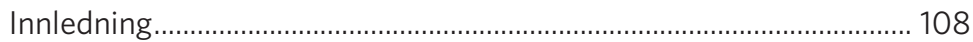

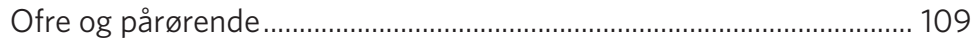

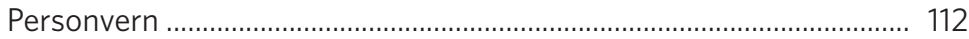

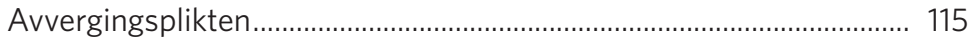

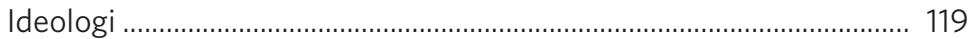

Utvikling av voldsstrategier .............................................................. 121

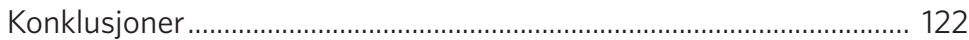

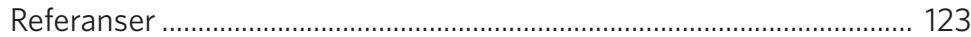

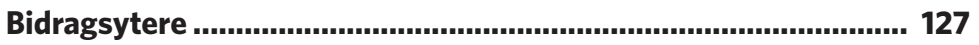





\section{Introduksjon - forskningsetikk og de berørte etter 22. juli}

\section{Vidar Enebakk ${ }^{1}$, Helene Ingierd ${ }^{2}$ og Nils Olav Refsdal ${ }^{3}$}

Denne antologien presenterer forskning på de berørte etter terrorangrepene 22. juli 2011. Formålet med boka er å løfte frem forskningsetiske spørsmål som denne forskningen reiser. Hvordan ivareta krav til fritt og informert samtykke fra overlevende og etterlatte? Hvilken risiko og nytte kan forskningen ha - for forskningsdeltakerne og for andre individer og grupper? Hvordan avgrense forskerrollen i møtet med mennesker i sorg? Og hvordan dele data som er svært sensitive, med andre forskere og forskergrupper? Mange av spørsmålene boka reiser, er relevante også for annen forskning. Problemstillingene settes imidlertid på spissen i mange av de prosjektene som omtales her.

1 Sekretariatsleder for Den nasjonale forskningsetiske komité for samfunnsvitenskap og humaniora (NESH)

2 Sekretariatsleder for Den nasjonale forskningsetiske komité for naturvitenskap og teknologi (NENT)

3 Koordinator for 22. juli-forskning og forskningskoordinator i Helsedirektoratet 
I 2012 ble det opprettet en koordineringsgruppe for forskning etter 22. juli, med mandat fra Helse- og omsorgsdepartementet (HOD), for å minimere belastningen forskningen hadde for de berørte. Det dreide seg om å forhindre overlappende prosjekter, fremme god og ansvarlig forskning samt bidra til felles datainnsamling og deling av data. Sekretariatet for koordineringsfunksjonen ble lagt til De nasjonale forskningsetiske komiteene (FEK), og arbeidet ble ivaretatt av Nils Olav Refsdal.

De forskningsetiske perspektivene som tas opp i boka, er forankret i tre generelle prinsipper: a) respekt, b) gode konsekvenser og c) rettferdighet.

Helt grunnleggende er kravet om at personer som deltar i forskning, skal behandles med respekt. Det dreier seg om både menneskeverd og personvern, og i praksis betyr det at forskerne må innhente informert samtykke fra dem som skal delta. Men også andre hensyn spiller inn. Her er det snakk om mennesker som har gått gjennom rystende hendelser og tap, og dette krever særlig aktsomhet fra forskerens side. Av flere grunner kan det være særlige utfordringer knyttet til å innhente fritt og informert samtykke enten det er snakk om barn og unge eller personer med redusert eller manglende samtykkekompetanse. Videre kan det være snakk om behandling av svært sensitive opplysninger eller mulig reidentifisering av enkeltpersoner. Flere av bidragene reflekterer rundt hvordan respekten for den enkelte best kan ivaretas før, underveis og etter forskningsdeltakelsen.

Et annet grunnleggende prinsipp er at forskningen bør ha gode konsekvenser for dem som er involvert. Samtidig er det ofte en avveiing mellom forskningens nytte og potensielle risiko. I medisinsk forskning omtales dette gjerne som proporsjonalitetsvurderinger, men også i annen type forskning er det ofte nødvendig å veie forskningens nytte mot ulike belastninger. Det dreier seg ikke bare om risiko for fysisk skade eller ubehag, men også om ulike psykiske 
belastninger som faren for retraumatisering. Nytte, på sin side, handler ikke bare om forskningens generelle samfunnsnytte, for eksempel for forvaltningen og forbedringen av rutiner og regelverk, men også nytten for dem som deltar i forskning. Forskningens skal i prinsippet ha gode konsekvenser også for dem. Derfor blir det et paradoks, som noen av bidragene i boka tar opp, når de berørte ønsker å delta i forskning til tross for at det faktisk kan medføre store belastninger for dem personlig. Forskningen kan samtidig ha en direkte relevans for dem som opplever det som givende og meningsfylt i seg selv å bidra til forskning på dette feltet. Spørsmålet er om risikoen for et visst ubehag er akseptabel så lenge vi kan forvente en reell nytteverdi av forskningen.

Et tredje prinsipp er rettferdighet. Dette innebærer blant annet at alle grupper bør representeres i forskningen, og at kostander og nytte fordels likt. I forskningen på overlevende og etterlatte etter Utøya var det viktige diskusjoner rundt hvem man skulle inkludere og ikke.

Enkelte av leirdeltakerne var svært unge, og ble ikke invitert med av den grunn. Var det rettferdig? Og hvordan ivaretar man skilte foreldre uten daglig omsorg eller onkler, tanter eller besteforeldre som stod avdøde svært nær? Mange av dem som tilfeldigvis oppholdt i regjeringskvartalet, har aldri blitt invitert med i noen studier, til tross for at det har vært en betydelig kritikk av oppfølgingen av dem fra Oslo kommunes side fra Nasjonal støttegruppe etter 22. juli-hendelsene.

Det ble tidlig gitt oppdrag til enkelte forskningsmiljøer om å samle inn data fra de berørte, samtidig som det ble gitt ut et tydelig signal om å begrense belastningen på gruppen. Det medførte at noen forskere fikk bedre tilgang til data enn andre. Hvordan ivaretar man rettferdighetssynet i en slik situasjon uten å lempe på hensynet til de berørte? Svar på dette ble fra koordineringsgruppen å legge til rette for deling av data, noe som viste seg krevende, fordi det ikke var planlagt for fra starten av. 
Vinteren 2013-2014 ble tematikken utvidet til å inkludere forskning på ekstremisme og ekstremister. Et knippe forskere mottok da invitasjoner fra Anders Behring Breivik, som stilte seg til rådighet for intervjuer, men på bestemte premisser med retningslinjer som var vanskelige å akseptere. Lars Gule var blant disse forskerne som fikk tilbud, men takket nei, og i bokas siste kapittel reflekterer han over «Etiske utfordringer i ekstremismeforskningen i Norge». Etableringen i februar 2016 av et eget Senter for ekstremismeforskning: Høyreekstremisme, hatkriminalitet og politisk vold (C-REX) ved Universitet i Oslo vil bidra med ytterligere forskning på dette området.

Ikke bare reiser selve forskningen ulike forskningsetiske spørsmål, også forvaltningen av forskningsetikk kan reise egne utfordringer og spørsmål. Mye av den forskningen som ble utførte etter 22. juli, krevde forhåndsgodkjenning. Medisinsk og helsefaglig forskning som faller inn under helseforskningsloven, krever forhåndsgodkjenning fra én av de regionale komiteer for medisinsk og helsefaglig forskningsetikk (REK). Samfunnsvitenskapelige prosjekter som behandler personopplysninger, krever tilråding fra et personvernombud, mens behandling av sensitive personopplysninger krever konsesjon. De nasjonale forskningsetiske komiteene er rådgivende instanser i forskningsetikk og dekker alle fagområder. Sluttrapporten fra koordineringsgruppen for 22. juli-forskning konkluderte med at plasseringen i sekretariatet FEK fungerte godt (FEK 2015:24). Selve koordineringsgruppen utgjorde en møteplass der forskere og aktører som påvirket forskningen, kunne utveksle erfaringer og ha et rom for å diskutere forskningsetiske spørsmål.

Vi håper denne antologien om forskningsetikk og 22. juli vil være nyttig for videre forskning på de berørte og på ekstremisme. Boka henvender seg også til forskere som mer allment forsker 
med mennesker, og som kan møte noen av de utfordringene boka tematiserer. Ikke minst håper vi boka kan være til nytte $\mathrm{i}$ undervisning og opplæring av studenter og fremtidige forskere, og at den kan bidra til økt bevissthet og debatt om forskningsetiske spørsmål. 


\section{KAPITTEL 1}

\section{Koordinering av forsking på dei berørte}

Nils Olav Refsdal ${ }^{1}$

Føremålet med dette kapittelet er å løfte fram nokre av erfaringane som vart gjorde i arbeidet med å koordinere forskinga etter 22. juli. Medan dei andre bidraga i denne boka byggjer på problemstillingar i det enkelte forskingsprosjektet, vil dette kapittelet trekke fram utfordringar som oppstod på tvers av enkeltprosjekta og i forskingssystemet. Dette er erfaringar som har overføringsverdi til andre situasjonar kor det er risiko for stor merksemd mot ei avgrensa gruppe, eller kor det er avgjerande å få til innsamling av data raskt. Teksten byggjer på sluttrapporten til koordineringsgruppa (De nasjonale forskningsetiske komiteene, 2015) og på ein artikkelsomvart publisertiEuropean Journal of Psychotraumatology (Refsdal 2014).

\section{Behovet for samordning}

Ganske raskt etter terroråtaket 22. juli 2011 vart det klart at det oppstod mange behov for kunnskap og forsking. Samfunnet trong å forstå gjerningsmannen, korleis vi som samfunn svara,

$1 \quad$ Koordinator for 22. juli-forskning og forskningskoordinator i Helsedirektoratet 
korleis politi, media og helsetenestene responderte, og ikkje minst konsekvensane for dei som vart råka. Mykje av denne forskinga analyserer gjerningsmannen sine ytringar, mediedekning og dokumentkjelder, men for å forstå reaksjonane til enkeltmenneska må dei som vart råka, delta i forskinga sjølve.

Trykket på dei overlevande og etterlatne var stort og vedvarande. Dei bidrog i etterforsking, mange vitna i rettssaka, og dei fleste fekk spørsmål om å delta i minst eitt forskingsprosjekt. 94 prosent av dei overlevande frå Utøya opplyste at dei vart kontakta av media (Thoresen, Jensen \& Dyb 2014). Talet på førespurnader kan også påverke korleis ein stiller seg til førespurnader om å delta i forsking. På den eine sida kan det hende at ein avslår å delta fordi ein er lei (omtala som samtykketrøttleik), på den andre sida kan ein samtykke rutinemessig utan å vurdere kva deltaking vil bere med seg (Ploug \& Holm 2013). Det enkelte forskingsprosjekt må handtere korleis ein best tek i vare den enkelte deltakaren i ein slik situasjon. Men heilskapen må handterast i forskingssystemet, slik at ein unngår unødig overlappande forsking og kan legge til rette for god og skånsam forsking som gir svar på dei rette problemstillingane.

\section{Om koordineringsarbeidet}

For å unngå overlappande forsking og få mest mogeleg ut av forskinga vart ein koordineringsfunksjon og ei koordineringsgruppe oppretta i 2012 med mandat frå Helse- og omsorgsdepartementet. Koordineringsgruppa bestod av dei sentrale forskingsmiljøa, dei som finansierer forskinga, universitets- og høgskulesektoren, kommunesektoren, representantar for dei berørte og Helsedirektoratet, som leia gruppa. Dei nasjonale forskingsetiske komiteane var observatør i gruppa og hadde sekretariatsfunksjon i første mandatperioden fram til 2014. Mandatet vart etter ønskje frå 
koordineringsgruppa forlengd ut 2016, med eit redusert sekretariat flytta til Helsedirektoratet. ${ }^{2}$

Koordinering av 22. juli-forskinga har vore avgrensa til forskinga på dei berørte ${ }^{3}$, men ikkje avgrensa ut frå fagfelt. Føremålet med koordineringa har vore å minimere belastinga forskinga har hatt på dei berørte. Oppgåvene gitt i mandatet har vore å:

- Overvake belastinga på informantgruppa

- Ha oversikt over pågåande og planlagde forskingsaktivitetar

- Bidra til informasjonsutveksling mellom forskarar og forskingsmiljø

- Formidle kontakt og skape møteplassar mellom aktuelle forskarar og forskingsmiljø (Helse- og omsorgsdepartementet 2012)

Koordineringsfunksjonen har vore basert på frivillig samarbeid og informasjonsutveksling. Det vart fastsett i mandatet at finansiering og godkjenning av forskingsprosjekt skulle følgje normale prosedyrar. Koordineringsgruppa har ikkje hatt verkemiddel til å initiere eller stoppe forsking, og dei forskingsmiljøa som har vore representerte i gruppa, har heller ikkje hatt monopol på tilgang til dei som vart ramma.

\section{Diskusjonsforum og arena for brukarmedverknad}

Sidan koordineringsfunksjonen ikkje har hatt «harde» verkemiddel, er det viktig at medlemmene av koordineringsgruppa kan påverke avgjerder ved dei institusjonane dei representerer. Sidan samarbeid og informasjonsutveksling har vore dei sentrale verkemidla, er det

2 Denne flyttinga har årsak $\mathrm{i}$ at sekretariatet til Dei nasjonale forskingsetiske komiteane er lite, og det var ikkje råd å fylle resten av stillinga der.

3 I mandatet er «berørte» definert som etterlatne, skadde, ramma, nære pårørande, vener og offentleg og frivillig innsatspersonell». 
også viktig med tillit og at ein etablerer ei forståing av eit felles mål: å legge til rette for god forsking som tek i vare interessene til forskingsdeltakarane.

Det har vore særs positivt at Nasjonal støttegruppe etter 22. julihendelsene har vore med i gruppa, og at dei har teke ei aktiv rolle. Støttegruppa har fått god informasjon om forskinga og har hatt ein arena der dei kan vidareformidle tilbakemeldingar frå medlemmene sine. Dei har hatt mogelegheit til å påverke innretninga gjennom å peike på kva problemstillingar som er viktige for medlemmene deira å få belyst.

\section{Deling av data}

Deling og gjenbruk av data har vore eit viktig tema, sidan tilgjengeleggjering av data er ein nøkkel til å unngå at forskingsdeltakarane får same spørsmål fleire gonger. Samstundes er slik tilgjengeleggjering eit krevjande tema; under ligg viktige personvernomsyn, avgrensingar i samtykka som er gitt, ulike forskartradisjonar og problemstillingar knytte til eigarskap av data og publisering. Når ein planlegg for deling av data, kan desse problemstillingane handterast. Dømet med forskinga til Melinder og Milde i kapittel 5 i denne boka viser det godt.

Det kunne vore ønskjeleg dersom ein hadde etablert eit felles datagrunnlag for forskinga på dei som vart ramma etter 22. juli. Då kunne ein unngått fleire førespurnader, sikra at ein brukte samanliknbare utfallsmål, og lagt til rette for langtidsoppfølging. Dette vart det ikkje planlagt for, så det var ikkje mogeleg å få til. I koordineringsgruppa vart ein i staden samde om å legge til rette for deling gjennom tilgjengeleggjering av metadata. Det vert arbeidd med å få ei slik oversikt på plass hjå Norsk senter for forskningsdata (tidlegare Norsk samfunnsvitenskapelig datatjeneste), med kopling til CRIStin (Current Research Information System In Norway). 
Dette vil gi informasjon om heile kjeda, frå finansiering via etisk godkjenning til publikasjonar, og også med kopling til oversikt over kva data som er samla inn, kven som sit med dei, og kva som skal til for å få tilgang.

I framtida bør ein planlegge for slik deling frå starten av. I Storbritannia har ein etter terroråtaket i London i 2005 fått heimel til å opprette populasjonsregister ved store hendingar (Close mfl. 2014). Dette registeret kan tene fleire føremål: etterforsking, forsking, psykososial oppfølging og eventuelle erstatningssaker. Det bør vurderast om dette bør gjerast også i Noreg, til dømes som del av den generelle helseberedskapen.

\section{Eit forskingssystem som er betre rusta ved neste krise}

Forskarane ved Nasjonalt kunnskapssenter om vold og traumatisk stress (NKVTS) var godt førebudd til å ta fatt på forskinga på dei overlevande etter terroråtaket. Dei hadde nyleg avslutta eit stort forskingsprosjekt om tsunamien i romjula 2004, og dei kunne gjenbruke eller byggje vidare på mykje av protokollane dei brukte då. Likevel tok det fire månader frå terroren trefte, til det første intervjuet vart gjennomført. For andre forskingsmiljø tok det mykje lengre tid, gjerne godt over eitt år, før forskinga kom i gang. At ein kjem så seint i gang, gjer at ein ikkje får informasjon om akutte reaksjonar og konksekvensane av desse. I tillegg har det konsekvensar for datakvalitet og for rekruttering av deltakarar.

Årsakene til at det tar tid å kome i gang, er som oftast knytte til finansiering og til at medisinsk og helsefagleg forsking treng førehandsgodkjenning. ${ }^{4}$ Slik etisk godkjenning vert gitt av regionale

4 Jf. lov om medisinsk og helsefaglig forskning (helseforskingslova) $\$ 9$. 
komitear for medisinsk og helsefagleg forskingsetikk (REK). Koordineringsgruppa har drøfta kva ein kan gjere for å kome raskare i gang med forsking i framtida, og har innhenta innspel frå fleire instansar, mellom anna De nasjonale forskningsetiske komiteene.

Når det gjeld etisk godkjenning, har sentrale personar i forskinga etter 22. juli ved Oslo universitetssykehus teke initiativ til å lage katastrofeprotokollar for forsking som inneheld rutinar og forslag til samtykkeskjema, spørjeskjema med vidare (sjå Ekeberg i denne boka). Dette er eit godt initiativ som fleire bør sjå til, og som ein kan vurdere om ein også bør ha på nasjonalt nivå. I tillegg har koordineringsgruppa tilrådd at REK organiserer ein beredskapsfunksjon, gjerne ein fast komité, som har som oppgåve å handsame søknader om forsking i ein krisesituasjon.

Spørsmålet om finansiering er også drøfta i koordineringsgruppa sin sluttrapport. Det er behov for større fleksibilitet på dette området, noko som kan skje anten ved at enkelte forskingsinstitusjonar med eit særskilt ansvar får fullmakt til å overskride budsjett i krisesituasjonar, eller ved at Forskingsrådet set av eller omdisponerer midlar i ein slik situasjon. Dette vil bidra til risikoavlasting for forskingsmiljø som bidrar med viktig dokumentasjon. Det vil også kunne heve datakvaliteten, gjennom at ein får innhenta data i akuttfasen i staden for at ein må vente på avklaring av finansiering, som gjer at forskingsdeltakarane må forsøke å tenkje tilbake på hendingane. Det er fleire løysingar som er mogelege på dette området, men det er dei relevante departementa, Helse- og omsorgsdepartementet og Kunnskapsdepartementet, som må ta tak i denne problemstillinga.

Til sist er det viktig å ha med at dersom ein peikar ut nokon som skal samle data i ein akutt fase i ein katastrofesituasjon, må det leggast opp til deling av data. Ein samlar då inn data på vegner av eit forskarfellesskap, ikkje berre seg sjølv og si forskargruppe. 


\section{Referanser}

Close, R.M., Maquire, H., Etherington, G., Brewin, C.R., Fong, K., Saliba, V., Barker, K.M. \& Leonardi, G.S. (2014). Preparedness for a major incident: Creation of an epidemiology protocol for a health protection register in England. Environment International, Recent developments in assessing and managing serious health threats, 72, 75-82. doi:10.1016/j.envint.2014.05.003

Collogan, L.K., Tuma, F., Dolan-Sewell, R., Borja, S. \& Fleischman, A.R. (2004). Ethical issues pertaining to research in the aftermath of disaster. Journal of traumatic stress, 17 (5), 363-372. doi:10.1023/B:JOTS.0000048949.43570.6a

De nasjonale forskningsetiske komiteene. (2015). Sluttrapport frå koordineringsgruppa for 22. juli-forsking. Oslo: De nasjonale forskningsetiske komiteene. https://www.etikkom.no/globalassets/ sluttrapport-koordineringsgruppa-for-22.-juli-forsking.pdf Helse- og omsorgsdepartementet. (2012, 29. mars). Mandat for nasjonal koordinering av forskning etter terrorhendelsene 22. juli 2011. Etikkom. http://www.etikkom.no/hvem-er-vi-og-hva-gjor-vi/ Hvem-er-vi/Koordineringsgruppen-for-22-juli-forskning/Sentraledokumenter/Mandat/ (lastet ned 22.02.16)

Ploug, T. \& Holm, S. (2013). Informed consent and routinisation. Journal of Medical Ethics, 39 (4), 214-218. doi:10.1136/medethics-2012-101056

Refsdal, N.O. (2014). Experiences from coordinating research after the 2011 terrorist attacks in Norway. European Journal of Psychotraumatology, 5 (0). doi:10.3402/ejpt.v5.23215

Thoresen, S., Jensen, T.K. \& Dyb, G. (2014). Media participation and mental health in terrorist attack survivors. Journal of Traumatic Stress, 27 (6), 639-646. doi:10.1002/jts.21971 


\section{KAPITTEL 2}

\section{Om å delta $\mathrm{i}$ forskningen etter 22. juli}

\section{Ragnar Eikeland ${ }^{1}$}

Tema for dette kapittelet er spørreundersøkelse versus intervju etter den tragiske hendelsen på Utøya 22. juli 2011. Min kompetanse på dette området er at jeg har deltatt i to spørreskjemaundersøkelser og et intervju etter hendelsen. Først vil jeg sette et lite perspektiv på dette.

Vi har vel alle deltatt i en spørreundersøkelse på en eller annen måte, det være seg undersøkelse fra for eksempel Norsk Gallup vedrørende politiske valg i Norge der de spør om hvilket parti stemte du på nå, og har du eventuelt skiftet parti siden forrige valg. Eller man har hatt en ferietur til en av Kanariøyene, og når du kommer hjem, får du en e-post fra reiseoperatøren der du blir spurt om: Hvordan var flyreisen? Hvordan var hotellet? Osv. Dette er eksempler på enkle og lystbetonte spørreundersøkelser.

Når det gjelder temaet for dette kapittelet, nemlig spørreundersøkelser og intervju i etterkant av hendelsen på Utøya 22. juli 2011, så er det en helt annen form for spørreundersøkelse, og man har en helt annen innstilling til noe sånt enn man har til de enkle undersøkelsene jeg nevnte over. Her kommer det inn følelser, 
hvilken fase i sorgbearbeidingen man er i, og rett og slett noe så enkelt som at dette orker jeg ikke nå.

Da jeg fikk spørsmål første gang om å delta i en spørreundersøkelse etter hendelsen, tenkte jeg: Nei, dette vil jeg ikke være med på. Men da jeg fikk tenkt meg om en stund, ble det til at jeg svarte ja likevel. Motivasjonen til å si ja var at hvis mine svar kunne hjelpe andre i ettertid ved eventuelle nye hendelser, som dessverre helt sikkert vil komme enten her i Norge eller andre steder i Europa eller verden for øvrig, så var det verdt å delta.

I utgangspunktet hadde jeg nok heller foretrukket å svare muntlig på spørreundersøkelsen, da jeg da ville hatt mulighet til å presisere og understreke hva jeg virkelig mente om de forskjellige temaene som ble tatt opp. Men bak en masseutsendelse av en spørreundersøkelse finnes det ikke et navn eller en person, så derfor var dessverre ikke muntlige svar et alternativ.

$\mathrm{Da}$ jeg mottok spørreundersøkelsen på e-post, ventet jeg noen dager før jeg åpnet den, men jeg lukket den igjen umiddelbart; jeg hadde ikke dagen eller motivasjonen. Men etter noen dager åpnet jeg den igjen, og da svarte jeg på alle spørsmålene, selv om det var mange av de opplistede svaralternativene som ikke passet meg direkte. Men jeg krysset av der jeg mente svaret var nærmest det jeg følte og mente der og da. Jeg sendte ikke inn svarene samme dagen, og da jeg åpnet skjemaet igjen en dag eller to senere, følte jeg at jeg hadde svart feil på en del av spørsmålene.

Og da er jeg ved det jeg nevnte tidligere: Det er vanskelig å få satt ned på papiret sine egne følelser siden det blir veldig personlig, mens svaralternativene er laget på mer generelt grunnlag for at man i ettertid skal kunne dra ut en fellesnevner fra hvert spørsmål. Og da vil det alltid være sånn at noen svaralternativer ikke passer den enkelte. Jeg tror også at dagsformen spiller en stor rolle for hvilke svar man gir.

Cirka et år etter den første spørreundersøkelsen kom undersøkelse nummer 2, og jeg svarte ja til deltagelse på den også. 
Motivasjonen var den samme, men som forrige gang måtte jeg la det gå noen dager før jeg satte meg ned og forsøkte å gi ærlige svar. Og denne gangen var det enda flere spørsmål som ikke kom overens med mine følelser og tanker.

Som et eksempel kan jeg nevne dette: Har du det bedre eller verre nå enn ved forrige spørreundersøkelse? Men her hadde ikke jeg et ja- eller nei-svar fordi jeg hadde det annerledes, ikke bedre eller verre. Og med det mener jeg at ved den første undersøkelsen følte jeg rett og slett bare sjokk og sorg, mens jeg nå var kommet over i en fase der sorgen delte plassen med savn. Om det gjorde livskvaliteten min bedre eller verre, var det vanskelig å definere, jeg hadde like vondt inni meg som tidligere men fokuset og tankene på det som hadde skjedd, var omtrent hver dag delt mellom sorgen og nå også savnet av gutten vår. Det første sjokket var over, sorgen hadde bitt seg fast, men nå begynte savnet å ta plass i tankene også i hverdagen.

Jeg svarte så godt jeg kunne, men følte likevel at det jeg sendte fra meg, ikke var fullt ut representativt for hvordan jeg hadde det der og da, og svaralternativene ved en god del av spørsmålene var ikke relevante for meg.

En god stund etter den andre spørreundersøkelsen ble jeg spurt om jeg ville stille opp til et intervju. Jeg tror jeg svarte ja med en gang, men i ettertid tenkte jeg at dette blir vanskelig; vil du virkelig dette?

Men da dagen kom, reiste jeg inn til Bergen, hvor intervjuet skulle finne sted. Jeg var nervøs og kviet meg en god del. Bak i rommet var det to andre personer som ikke skulle stille spørsmål, men kun høre etter og observere, da de hadde intervjuet overlevende ungdommer tidligere. Men etter 4-5 minutter hadde jeg glemt de to andre personene, og oppmerksomheten var kun på intervjueren og det jeg fortalte om. Det ble en befrielse, og jeg kunne snakke fritt og åpent om hendelsen, og jeg pratet og pratet, 
og ble kun rolig og lavmælt penset inn på sporet igjen av intervjueren når jeg snakket meg «helt ut på jordet». Intervjueren stilte ikke ledende spørsmål, jeg kunne snakke helt fritt, og der og da følte jeg at mine tanker og mine følelser virkelig kunne legges frem slik jeg hadde følt det, og slik jeg hadde det nå. Vi holdt på i over to og en halv time, og jeg hadde problemer med å kjøre bilen hjem igjen, for jeg følte meg totalt utslitt. Samtidig hadde jeg en indre ro, som jeg tror kom fordi jeg endelig kunne snakke åpent og ærlig om hendelsen, og ikke trengte tenke på hvem som var mottaker av den informasjonen jeg delte.

Min kone og jeg snakket selvfølgelig om disse temaene hjemme, men det var ikke normalt å snakke om dette med hverken venner eller arbeidskollegaer. Men under intervjuet kunne jeg dele alt.

Overraskelsen var derfor stor da intervjueren ringte meg samme kveld og sa at opptaket som ble gjort av intervjuet, dessverre var blitt slettet på grunn av at det hadde vært en feil med opptakeren som ble brukt. Jeg ble da spurt om vi kunne gjøre et nytt intervju, og dette svarte jeg ja til, da jeg følte at dette hadde faktisk gjort noe med meg; det første intervjuet hadde rett og slett gjort meg godt.

To dager etterpå møttes vi igjen, denne gangen uten tilhørere, og jammen holdt vi ikke på i to og en halv time nå også. Og jeg var like utslitt som første gangen, men jeg hadde samtidig den samme gode følelsen inni meg nå også.

I ettertid har jeg tenkt at grunnen til at erfaringen jeg fikk med intervju, ble så bra for meg, baserer seg på den tillit og trygghet som intervjueren ga både $\mathrm{i}$ det hun sa, og måten hun lot meg uttrykke meg på. Denne tryggheten, og ikke minst det at hun virkelig lyttet og prøvde å forstå meg, gjorde nok sitt til at jeg fortalte om ting og følelser som jeg aldri kunne fått frem i en spørreundersøkelse.

For å konkludere litt om forskjellen mellom spørreundersøkelser og intervju etter alvorlige hendelser eller traumatiske tap av barn 
eller nære familiemedlemmer, så er jeg, basert på mine erfaringer med begge deler, ikke i tvil om at et intervju er atskillig bedre enn én eller flere spørreundersøkelser. I en spørreundersøkelse svarer man det som man tror ligger nærmest det ens tanker og følelser er, mens man under et intervju får fram alle sine tanker og følelser. På denne måten kan man gi et ærlig og riktig svar til den eller dem som skal bearbeide intervjuet i ettertid.

Jeg er klar over at man må konkludere og dra ut svarene på et generelt grunnlag i en spørreundersøkelse. Summen av alle svar på et spørsmål vil gi et generelt bilde på hvordan folk har det, men samtidig er det ikke sikkert at det generelle bildet som svarene gir, er dekkende. Det er nok mange som meg som velger et svar man tror er nærmest det man føler, selv om det egentlig ikke dekker det jeg ville ha svart i et intervju.

Intervju derimot gir nok ærlige svar, og når man drar erfaringer ut fra intervjuene, vil de ikke være generelle, men mer dekkende for den enkeltes erfaringer.

Jeg skal ikke nevne så mye mer om hverken spørreundersøkelser eller intervju, men jeg vil gjerne komme med noen innspill. Jeg understreker at dette er ikke råd, for det har jeg ikke kompetanse til, men kun innspill fra en amatør.

Hvis jeg skulle hatt ansvaret for å lage spørsmål til en spørreundersøkelse, ville jeg på alle spørsmål ha laget et eget svaralternativ, som for eksempel kunne være: Hvis ingen av svarene over her passer for deg, hva ville du ha svart i stedet?

Jeg tror at da ville hver og en i hvert fall på en god del spørsmål følt at nå fikk jeg svart det jeg mener og føler. Selv om det normalt er gitt plass på slutten av et spørreskjema til å skrive ned egne tanker og følelser, er det vanskelig å dekke de forskjellige svaralternativene der.

Jeg er ikke i tvil om at hvis det er praktisk mulig å få til, så bør intervju foretrekkes fremfor spørreundersøkelse. 
Etter tragedien 22. juli er jeg klar over at det ville vært for omfattende å intervjue alle foreldrene til de omkomne på Utøya, for da ville man måttet intervjue nærmere 140 personer. Men der det er praktisk mulig å få dette til, så bør det være målsettingen. Og hvis man må gjennomføre spørreundersøkelser som vi vet må gjøres mange ganger, skal man kanskje prøve å dra inn et par av de berørte til å se igjennom spørsmålene og svaralternativene før spørreskjemaet sendes ut til alle. Da kan man kanskje få korrigert skjemaet til å bli mest mulig dekkende for alle de berørte. 


\section{KAPITTEL 3}

\section{Utøya-studien: Forskningsetiske betraktninger}

\section{Grete Dyb ${ }^{1}$, Kristin Alve Glad ${ }^{2}$ og Gertrud Sofie Hafstad $^{3}$}

We conducted a longitudinal interview study with survivors of the terrorist attack at Utøya July, 22nd2011, and their parents. In this chapter, we discuss the ethical considerations and challenges we encountered in planning and conducting the study, including whether the importance of gaining new knowledge outweigh the potential burden of being interviewed after such a traumatic event, how soon after the event it was acceptable to ask the directly affected to participate, and whether participation would involve an additional strain on the survivors and their families. The study denoted a unique opportunity to detect unmet need for help among those affected, and help them get in contact with support agencies. We therefore recruited skilled interviewers with a health professional background.

Forsker I ved Nasjonalt kunnskapssenter om vold og traumatisk stress (NKTVS) og professor ved Universitetet i Oslo, Det medisinske fakultet, Institutt for klinisk medisin

2 Stipendiat ved Nasjonalt kunnskapssenter om vold og traumatisk stress (NKTVS)

3 Forsker II ved Nasjonalt kunnskapssenter om vold og traumatisk stress (NKTVS) 
The fact that the vast majority of the youth and their parents who participated in the first interviews chose to participate in the two subsequent rounds, indicates that participants found it worthwhile to share their experiences and knowledge, and that the benefits of participating weighed stronger than any possible discomfort related to participating.

\section{Innledning}

I etterkant av en traumatisk hendelse som terrorangrepet 22. juli 2011 har tiltak for å bistå de som er rammet, høyeste prioritet. Få dager etter angrepet fikk Nasjonalt kunnskapssenter om vold og traumatisk stress (NKVTS) i oppdrag å bistå Helsedirektoratet med ekspertråd for å planlegge oppfølgingen av de berørte. I dette arbeidet ble det utformet et program for helsemessig og psykososial oppfølging av de som ble direkte berørt av terrorhandlingene på Utøya og i regjeringskvartalet.

Norge har ikke opplevd et terrorangrep av et slikt omfang tidligere, og selv i internasjonal målestokk var dette en usedvanlig brutal hendelse. NKVTS bygget sine råd til helsemyndighetene på eksisterende kunnskap om hvilke konsekvenser et slikt terroranslag kan ha for de berørte, og hvilke tiltak som kan bidra til å minske belastningene deres. Forskere ved NKVTS hadde allerede en del erfaring med å gjennomføre intervju med mennesker i sårbare situasjoner. Syv år tidligere, i 2004, ble nesten 2000 nordmenn rammet av tsunamien som slo inn over Sørøst-Asia. I kjølvannet av dette gjennomførte NKVTS en intervjuundersøkelse med de som overlevde, for å kartlegge deres psykiske og fysiske helse og oppfølgingen de fikk fra hjelpeapparatet.

At tiltakene som ble iverksatt etter 22. juli, skulle bygges på tidligere forsking, var selvsagt, men tanken på å sette i gang innhenting av dokumentasjon og forskning når katastrofen inntreffer, 
kan synes utidig og til og med uetisk. Retorisk kan man stille spørsmålet: Samfunnet trenger mer kunnskap om de som er direkte berørt av terroranslag - men hvem skal gjøre det? Gjennomføring av forskning som fremskaffer nyttig og nødvendig kunnskap, stiller også krav til utforming av studien, valg av metode og gjennomføringsevne. Nytteverdien av studien må alltid veies opp mot den risiko og belastning som deltagerne utsettes for, og dette setter krav til studiens kvalitet og beredskapen rundt gjennomføringen. Vår oppgave ble derfor å designe en studie som både var forsvarlig å gjennomføre, og som hadde potensial til å fylle noen av kunnskapshullene vi har.

Helsedirektoratet ga NKVTS i oppdrag å utføre tre studier etter terroranslagene 22. juli: En studie som omfattet de som var på Utøya, og deres foreldre, en studie om de ansatte i regjeringskvartalet og departementene, og en befolkningsstudie. I dette kapittelet drøfter vi de etiske betraktningene vi gjorde oss i arbeidet med studien om de som overlevde på Utøya, og deres foreldre (heretter referert til som «Utøya-studien»). I tillegg drøfter vi to forhold knyttet til det å få tildelt et slikt oppdrag etter en nasjonal katastrofe: 1) samarbeid med andre forskere om data innhentet i prosjektet, og 2) uavhengighet i forskningen knyttet til oppdragsgiver og andre oppgaver senteret utførte i tiden etter 22. juli.

\section{Er det etisk forsvarlig å gjennomføre en slik studie?}

Forskning på traumatiske opplevelser krever ofte at deltagerne må svare på detaljerte spørsmål om selve hendelsen og om egne traumerelaterte symptomer. Etiske spørsmål som da dukker opp, er for eksempel om hvorvidt mennesker som har blitt utsatt for noe traumatisk, kan få sterke/negative reaksjoner av å delta i forskning, og om deltagelse vil kunne påføre de berørte en ekstrabelastning. 
Forskere har et ansvar, ikke bare for å maksimere den potensielle nytteverdien av å delta i en forskningsstudie og minimere den potensielle risikoen, men også for å sikre at deltagerne ikke blir skadet. I forbindelse med forskning på mennesker som har opplevd en potensielt traumatiserende hendelse, har enkelte hevdet at det å tenke på og fortelle om den traumatiske hendelsen vil kunne frembringe så sterke reaksjoner at deltagerne opplever det som om traumet skjer på nytt, altså en slags «retraumatisering». Flere anerkjente traumeforskere, blant andre Jensen (2012) og Newman og Kaloupek (2005), hevder imidlertid at dette begrepet er villedende. De mener at det er en stor forskjell på den direkte traumatiske opplevelsen - og det å be mennesker frivillig tenke over og beskrive sine opplevelser i et trygt og kontrollert miljø. I intervjusituasjonen vil den berørte ha kontrollen, inkludert retten til å avslutte intervjuet dersom de ønsker det, i motsetning til under den traumatiske opplevelsen.

Videre tyder funnene som foreligger så langt, på at det er liten risiko for at deltagere skal bli betydelig emosjonelt skadet av å delta i traumerelatert forskning. Selv om noen opplever uventede emosjonelle reaksjoner, er dette tolererbart og faktisk forbundet med positive utfall for mange, og nesten alle rapporterer at de ville valgt å delta i studien igjen hvis de fikk muligheten (for en oppsummering, se Newman mfl. 2006). Det er også verdt å merke seg at informanter kan oppleve det å delta i undersøkelser om egne traumatiske opplevelser som interessant og verdifullt (se for eksempel Dyregrov 2004; Griffin, Resick, Waldrop \& Mechanic 2003). Gjennom å delta i forskning har deltagere rapportert at de opplever at de får muligheten til å dele sin historie, økt innsikt i egne reaksjoner og egen situasjon, samt muligheten til å hjelpe andre traumeutsatte gjennom å bidra til å øke kunnskapen på feltet (Carlson mfl. 2003). Det kan også oppleves terapeutisk i seg selv for enkelte berørte eller pårørende å fortelle sin historie og dele sine mestringsstrategier og vite at dette kan inspirere og gi håp til andre som er i en lignende 
situasjon (Dyregrov 2004). Et annet viktig aspekt er at en forskningsstudie kan fungere som et sikkerhetsnett, der berørte som har behov for hjelp og oppfølgning, kan bli fanget opp og hjulpet inn i hjelpeapparatet.

Det generelle inntrykket fra tsunamistudien var at de som deltok, i svært liten grad opplevde intervjusituasjonen som belastende, og at både foreldre og barn ga uttrykk for at intervjuene opplevdes som meningsfylte (Jensen mfl. 2008). Arbeidet med tsunamistudien hadde også gitt oss verdifulle erfaringer angående hvilken type spørsmål det er greit å stille, og hvilke tema det kan være viktig å fokusere på i en undersøkelse så kort tid etter en katastrofal hendelse. Vi følte oss derfor trygge på at en godt planlagt studie, med erfarne klinikere i rollen som intervjuere, ville være etisk forsvarlig i denne situasjonen.

\section{Hvor lenge bør vi vente?}

Mennesker som har vært utsatt for katastrofer og andre potensielt traumatiserende hendelser, har behov for beskyttelse, trygghet og støtte. I den første tiden etter er det derfor hjelpetiltakene som har førsteprioritet, mens innhentning av kunnskap kommer i annen rekke. En viktig og vanskelig avveining vi måtte ta, var hvor tidlig etter hendelsen på Utøya det var etisk forsvarlig å sette i gang med en slik studie. Spørsmål vi stilte oss, var: Ville de berørte oppleve at henvendelsen kom altfor tidlig og bli støtt av å bli spurt? Burde vi gi dem mer tid til «å lande»? Hvor mye viktig kunnskap om tidlige reaksjoner ville vi miste ved å la tiden gå?

I et forskningsperspektiv, der vi ønsker å lære mer om tidlige tegn på noe som kan utvikle seg til å bli langvarige plager, vil det gjerne være et mål å samle inn data på et så tidlig tidspunkt som mulig. På grunn av praktiske og muligens etiske og juridiske hindringer har imidlertid svært få studier innhentet informasjon i løpet av de første ukene etter en traumatisk hendelse, og vi vet 
derfor lite om denne perioden. Men blant de studiene som foreligger, har forskere undersøkt hvordan mennesker har opplevd det å delta i traumerelatert forskning kort tid etter en potensielt traumatiserende hendelse. Eksempler er studier om akutt sårede voksne på sykehus etter trafikkulykker og overfall (Ruzek \& Zatzick 2000), akutt sårede barn og deres foreldre en måned etter en trafikkulykke (Kassam-Adams \& Newman 2005) og vanlige beboere i New York 1-2 måneder etter 11. september-angrepene i 2001 (Galea mfl. 2005). Funnene tyder på at det er lav risiko for emosjonelt ubehag og relativt høy grad av positive opplevelser knyttet til slik forskningsdeltagelse.

Det å planlegge studien, søke godkjenning fra Regionale komiteer for medisinsk og helsefarlig forskningsetikk (REK), få tak i intervjuere og kontakte de berørte tar tid. Det var derfor ikke mulig for oss å gjennomføre første intervjurunde før 4-5 måneder etter terroranslaget.

\section{Hvem skal vi invitere med?}

Hvem vi skulle inkludere i studien, var ikke bare et økonomisk spørsmål og et kapasitetsspørsmål, men også et etisk spørsmål, som vi diskuterte grundig. Det første vi spurte oss selv, var om vi skulle kontakte alle de som overlevde på Utøya, eller om det var noen vi burde skåne, for eksempel med tanke på alder. Noen av barna som var på Utøya 22. juli, var i småskolealder, og selv om vi tidligere har intervjuet barn ned til seks år, vurderte vi om vi burde skjerme de aller yngste i denne undersøkelsen. Det å skulle skjerme noen ville imidlertid bety å frata dem muligheten for å delta, noe vi vet kan oppleves som en avvisning eller underkjennelse av deres synspunkter. Vi konkluderte likevel med ikkeå kontakte de fire som var under 13 år. Hovedgrunnen var at disse var betydelig yngre enn de andre berørte, og at de derfor skilte seg tydelig fra den øvrige gruppen. 
Det er i dag mange forskjellige familiekonstellasjoner, og mange ungdommer har mer enn to foreldre eller foresatte. Det neste spørsmålet vi stilte oss, var følgelig om begge/alle foreldrene/foresatte skulle inviteres med. Vi hadde ikke kontaktinformasjon til foreldrene, så vi visste ikke hvem eller hvor mange de var. Vi valgte å intervjue de foreldrene som hadde mest kontakt med barnet, mens de andre foreldrene/foresatte fikk tilbud om å fylle ut et spørreskjema.

Så var spørsmålet om vi skulle invitere andre familiemedlemmer, for eksempel søsken, eller vennene/kjærestene til de som var på øya. Av kapasitetsgrunner valgte vi ikke å inkludere verken søsken, venner eller kjærester i studien. I ettertid kan vi spørre oss om dette var riktig, spesielt det å ekskludere søsken. Vi vet at mange berørte familier opplevde at søsken ikke fikk god nok oppfølgning, og at de har savnet en sterkere familiefokusering på tiltak som ble iverksatt (Glad, Jensen \& Dyb 2014). Dersom vi hadde inkludert søsken i studien vår, ville vi hatt mer kunnskap nå, både om hvordan de opplevde at terroranslaget påvirket dem og deres familie, og hva slags oppfølgning de ville hatt behov for i tiden etter.

Enkelte av de som var på landsiden under angrepet, tok selv kontakt med prosjektgruppen med forespørsel om deltagelse i studien, og disse ble også inkludert.

Vi var informert om at Senter for Krisepsykologi i Bergen planla en studie med de etterlatte. For å unngå en overbelastning for disse familiene inviterte vi kun familier med barn som overlevde terrorangrepet.

\section{Hvordan skal vi samle inn datamaterialet?}

Selve datainnsamlingen kan foregå på ulike måter, for eksempel gjennom personlig intervju, telefonintervju, spørreskjema i posten eller web-basert spørreskjema. Det er mange fordeler og 
ulemper ved de ulike metodene. Personlig intervju er for eksempel svært tids-, kostnads- og innsatskrevende i store studier. Samtidig gir det oss en bedre mulighet til å fange opp de som strever med psykiske reaksjoner. Intervjuer gir ofte mer utfyllende og grundig informasjon, og ikke minst gir de deltagerne en følelse av å bli møtt, bli tatt på alvor, og en følelse av at historien deres blir «tatt imot». Det er også mulig at mennesker som deltar i traumerelatert forskning i form av intervju, opplever større fordeler enn de som deltar i form av et spørreskjema. For eksempel fant Newman mfl. (1999) i en studie av kvinner utsatt for barnemishandling at $86 \%$ av deltagerne som ble intervjuet, opplevde at de fikk noe positivt ut av deltagelse, sammenlignet med kun $23 \%$ av de som fikk spørreskjema. Ifølge Newman mfl. (2006) er det mulig at personlige intervjuer innebærer en større byrde for deltagerne, men at fordelene knyttet til det å få snakke med noen personlig kan veie opp for dette.

Vi bestemte oss for å gjennomføre strukturerte intervjuer med en kombinasjon av åpne spørsmål og spørsmål med gitte svaralternativer til alle som var på Utøya, og til foreldrene til ungdom som var 19 år eller yngre. Foreldre til ungdom over 19 år ble av kapasitetsgrunner invitert til å fylle ut spørreskjema. Vi ønsket å snakke med de berørte flere ganger, slik at vi kunne innhente informasjon om reaksjoner og hjelpebehov over tid. Studien fikk derfor en longitudinell design, og datainnsamlingen ble foretatt på tre tidspunkter etter katastrofen; 4-5 måneder ( $\left.\mathrm{T}_{1}\right), 14-15$ måneder $\left(\mathrm{T}_{2}\right) \mathrm{og}$ 30-32 måneder $\left(\mathrm{T}_{3}\right)$.

\section{Hvordan rekruttere og lære opp intervjuerne?}

Vi ønsket å gjøre første datainnsamling så tidlig som mulig, og vi visste at mange av informantene fortsatt ville være sterkt preget av 
hendelsen når vi møtte dem. Gitt den høye eksponeringen de berørte hadde vært utsatt for, de sterke historiene deres, samt muligheten for emosjonelle reaksjoner under/etter intervjuet, mente vi at det var viktig å bruke intervjuere med en helsefaglig bakgrunn. Videre, ettersom de berørte var bosatt over hele landet og en del kunne ha behov for hjelp til å komme i kontakt med hjelpeapparatet, ønsket vi å bruke lokale intervjuere som hadde kjennskap til hjelpeapparatet i kommunen der de bodde. Vi var samtidig opptatt av at intervjuere ikke blandet roller; at klinikere ikke intervjuet deltagere som de selv hadde eller hadde hatt i terapi. Vi brukte mye tid på å rekruttere intervjuere, og vi brukte nettverket vårt slik at vi kunne være så trygge som mulig på at de vi rekrutterte, var dyktige og erfarne fagfolk. De vi tok kontakt med, uttrykte alle en stor motivasjon for å bidra, og et sterkt ønske om å delta som intervjuer i studien.

Det var viktig at intervjuerne forstod intervjumanualen godt; både hva vi spurte om, og hvorfor vi spurte om nettopp dette. Ettersom det var et stort intervjukorps, med til sammen over 70 intervjuere, arrangerte vi et opplæringsseminar før hver intervjurunde. Her gikk prosjektgruppen grundig gjennom hvert tema i intervjumanualen. Intervjuerne fikk også en oppdatering knyttet til psykiske reaksjoner på traumatiske hendelser, opplæring i forskningsintervjumetodikk samt opplæring i bruk av kartleggingsinstrumentene. Vi understreket betydningen av å møte de berørte med respekt og ydmykhet. Vi presiserte at de her skulle ha en annen rolle enn den de var vant med. Nå skulle de først og fremst være intervjuer, ikke helsepersonell. Det betyr at de skulle følge intervjumanualen og ikke stille utdypende oppfølgingsspørsmål til hvert tema. Men, dersom de ble bekymret for om vedkommende hadde et udekket hjelpebehov, skulle de gjøre en vurdering etter at intervjuet var over. Det var viktig at intervjuerne var i stand til å følge opp de som trengte det, for eksempel ved å hjelpe dem med å 
komme i kontakt med fastlegen eller kontaktpersonen sin, samt gjøre en selvmordsfarevurdering ved behov.

\section{Hvordan skal vi ta kontakt med de berørte?}

Det å få oversikt over og ta kontakt med alle berørte etter en katastrofe kan være utfordrende. Dette fører ofte til et noe tilfeldig utvalg i katastrofestudier, hvilket igjen gir en begrenset mulighet for å generalisere funnene. Etter hendelsene på Utøya var situasjonen annerledes. For det første var åstedet tydelig avgrenset geografisk, og i tillegg fantes det oppdaterte lister over alle deltagerne på AUFs sommerleir. For å komme i kontakt med alle som overlevde, fikk vi politiets lister med navn og kontaktinformasjon. Vi hadde imidlertid ikke kontaktinformasjon til foreldrene deres. En vurdering vi måtte gjøre, var derfor hvorvidt det er etisk riktig å forsøke å komme i kontakt med foreldrene til de berørte via ungdommene? Og hvordan dette i så fall kunne gjøres uten at vi la noe av ansvaret for rekrutteringen av foreldrene på ungdommen? Dette var et dilemma vi brukte mye tid på å diskutere.

Vi valgte til slutt å utforme et informasjonsskriv om studien, som vi sendte per post til alle de som overlevde, og til foreldrene deres. På konvolutten til foreldrene skrev vi «Foresatte til», og så navnet til ungdommen. Disse brevene ble sendt separat, nettopp fordi vi var opptatt av at ungdommene ikke skulle fungere som et mellomledd og overbringe informasjon om studien til foreldrene sine. I brevet fikk informantene oppgitt prosjektets e-postadresse og telefonnummer, slik at de kunne ta kontakt med oss hvis det var noe de lurte på, eller hvis de ønsket å reservere seg fra å bli kontaktet. Dersom vi ikke hadde hørt noe fra dem i løpet av to uker, ble de kontaktet per telefon av en intervjuer. 
Det er mange etiske spørsmål som dukker opp når man skal ringe til mennesker som har opplevd en svært dramatisk hendelse, med en forespørsel om hvorvidt de ønsker å delta i et forskningsprosjekt: Hvor mange ganger er det greit å ringe hvis vedkommende ikke tar telefonen? Skal man legge igjen en beskjed på svareren? Er det ok å sende en melding? Ungdommene som overlevde på Utøya, hadde allerede blitt mye kontaktet med intervjuforespørsler av mediene. Vi ønsket å respektere deres grenser, og syntes det var viktig at de ikke opplevde at vi presset oss på. Vi lagde derfor en ringeinstruks for intervjuerne, med forslag til formuleringer av hvordan de kunne introdusere seg selv og prosjektet, hvor mange ganger de skulle ringe, samt følgende SMS som de kunne sende dersom de ikke fikk tak i dem:

Hei, jeg jobber for NKVTS. Du har fått et brev om en intervjuundersøkelse etter det som skjedde på Utøya. Jeg lurer på om du kunne tenke deg å delta. Jeg har prøvd å ringe deg fra (skriv inn nummer/dette nummeret), og prøver å ringe deg igjen i morgen. Hvis det ikke passer at jeg ringer deg i morgen, send meg en SMS om når det passer. Mvh. (Navnet ditt)

Vi understreket for intervjuerne at det var viktig ikke å være for pågående på telefonen. Dersom informantene sa nei, måtte det selvsagt respekteres. Noen oppga til intervjuerne årsaken til at de ikke ønsket å delta. Dette noterte intervjueren seg og formidlet det tilbake til prosjektet. Dette var viktig informasjon for prosjektledelsen, fordi det kan si oss noe om hvorvidt det er intervjuformatet, intervjutidspunktet, forhold knyttet til personens reaksjoner på hendelsen eller forhold uavhengig av verken 22. juli eller intervjuet som er årsaken til at de ikke ønsker å delta. Dette kan hjelpe oss i planleggingen av videre intervjurunder, ved at vi kan justere elementer ved intervjuet, tidspunktet, eller måten vi tar kontakt på, for at disse skal fungere bedre for de potensielle deltagerne. I første intervjurunde var det 
for eksempel enkelte som sa at de syntes det var for tidlig å delta, men at de ønsket å bli kontaktet igjen i neste runde.

\section{Hvor skal intervjuet finne sted?}

Et annet viktig spørsmål når man skal intervjue, er hvor intervjuet bør gjennomføres. Deltagerne kan for eksempel intervjues på kontoret til intervjueren, hjemme hos seg selv eller på skolen eller jobben sin. Vi ønsket å utføre intervjuet der de berørte følte seg mest komfortable, og vi lot det være opp til dem selv å bestemme sted. Vi spurte om de ønsket at vi kom hjem til dem, eller om de for eksempel ville bli intervjuet på et kontor i nærheten av der de bodde. De aller fleste deltagerne ønsket å bli intervjuet i sitt eget hjem.

Det var imidlertid flere hensyn å ta når det gjaldt intervjusted. Vår første prioritet var å tenke på deltagernes trygghet, ve og vel, men konfidensialitet var også et viktig element. Å intervjue mennesker i deres eget hjem kan innebære utfordringer knyttet til konfidensialitet, da de ulike familiemedlemmene potensielt kan høre hva de andre svarer og forteller. For å redusere dette problemet sørget vi for å utføre intervjuene så fysisk atskilt som mulig og med lukkede dører.

Av praktiske hensyn, og etter deltagernes eget ønske, ble enkelte intervjuer gjort på institusjoner (for eksempel barne- og ungdomspsykiatriske poliklinikker) eller et offentlig sted, for eksempel på en kafé. På offentlige steder er det viktig å sikre at deltagerne på forhånd er innforstått med hva de vil bli spurt om, og hva de tenker om det at andre potensielt kan høre noe av det de forteller. Det er ikke utenkelig at denne settingen kan ha påvirket hva deltagerne valgte å fortelle, og hva de svarte på spørsmålene. Dette er imidlertid i større grad et metodisk enn et etisk spørsmål. Så lenge deltagerne fikk grundig og god informasjon om hva de kunne forvente seg, mente vi at det måtte være opp til dem å bestemme hvilken setting de ønsket å ha rundt intervjuet. 


\section{Informert samtykke}

Informert samtykke er en kjerneverdi i alle studier som involverer mennesker. Ifølge Gallagher (2009) har et informert samtykke fire hovedtrekk: Det innebærer en eksplisitt handling (f.eks. en muntlig eller skriftlig avtale); deltagerne er informert om og har en forståelse av studien; samtykket blir gitt frivillig uten tvang; deltageren skal kunne trekke seg når som helst.

Utøya-studien bygget på informert samtykke. Før intervjuet startet, fikk informantene beskjed om at de når som helst kunne trekke seg fra studien. De fikk også beskjed om at hvis det var noe de ikke ønsket å svare på, var det helt greit, og at de i så fall ikke ville bli bedt om å forklare hvorfor. Det ble lagt vekt på å gi god informasjon om innholdet $\mathrm{i}$ intervjuet, slik at deltagerne var forberedt på hva de ville bli spurt om. Alle ungdommene som var over 16 år, ga selv skriftlig samtykke. For ungdom under 16 år ga foreldre skriftlig samtykke på vegne av ungdommen og seg selv. For ungdommer som fylte 16 år i løpet av oppfølgingstiden (ved $\mathrm{T}_{2}$ og $\mathrm{T}_{3}$ ), ble det innhentet samtykke fra ungdommen dersom vedkommende hadde fylt 16 år da intervjuet fant sted.

Informasjonen som ble gitt i intervjuene, ble ansett som sensitiv, og alle intervjuerne signerte derfor en taushetsplikterklæring. Deltagerne ble forklart at intervjueren ikke hadde lov til å fortelle andre det de fortalte om i intervjuet. De deltagerne som var under 18 år, ble informert om at vi måtte drøfte hva vi kunne gjøre videre, dersom de fortalte om noe som gjorde at vi ble bekymret for dem. Vi sa også at det kunne hende at vi måtte snakke med foreldrene deres, men at vi i så fall ville si fra til dem først. Tilsvarende ble foreldrene til deltagere under 18 år informert om at de ikke ville få vite hva barnet deres fortalte oss, men at dersom barna sa noe som gjorde at vi ble bekymret, ville vi drøfte dette med dem. 


\section{Skal vi bruke lydbånd?}

Vi besluttet på et tidlig tidspunkt at intervjuene skulle tas opp på bånd. Hovedårsaken til dette var at vi ønsket å få fanget deltagernes historie beskrevet med deres egne ord. Deltagerne satt på mye helt unik kunnskap om det å gjennomgå en så ekstrem opplevelse, og om hvordan det er å leve med reaksjonene etterpå. Det var derfor en høy prioritet for prosjektet å få tatt opp disse beskrivelsene i sin naturlige form. Det var også en viktig kvalitetssikring, både av selve intervjuet og av dataene vi fikk. Lydbåndene gjorde det mulig for oss å gå inn og lytte dersom noe av den skrevne informasjonen fra avkrysningsspørsmålene var tvetydig eller mangelfull. Det ga oss også muligheten til å sjekke at intervjuene faktisk hadde foregått som planlagt.

Det er imidlertid noen utfordringer knyttet til det å ta opp intervju på bånd sammenlignet med kun å innhente informasjon skriftlig. Blant annet blir det enda mer oppmerksomhet på betydningen av datalagring, datasikkerhet og anonymitet. I intervjumanualen brukes det et ID-nummer for hver informant, slik at informasjonen ikke kan knyttes til person. På lydbånd, derimot, finnes stemmen til informanten, hvilket gjør ham eller henne lett gjenkjennbar. Lydopptakene av intervjuene ble derfor lagt over på en kryptert minnepinne før de ble sendt i posten til prosjektgruppen i Oslo. Samtykkeskjema (med deltagernes navn og kontaktinformasjon) og intervjumanual (med deltagernes ID-nummer) ble sendt i separate konvolutter.

\section{Hvordan kan vi ivareta informantene best mulig?}

Måten en studie er planlagt og tilrettelagt på, har stor betydning for hvordan informantene opplever det å delta. I Utøya-studien skulle 
vi ta kontakt med og intervjue mennesker som hadde opplevd en meget dramatisk og potensielt traumatiserende hendelse, og vi var opptatt av at de skulle bli ivaretatt så godt som mulig.

For mennesker som har opplevd noe traumatisk, er forutsigbarhet og trygghet spesielt viktig, og forskere har et særskilt ansvar for å legge til rette for dette i planleggingen av studien. Det ble derfor lagt stor vekt på å sikre at deltagerne, som i utgangspunktet var i en sårbar situasjon, skulle få tilstrekkelig med informasjon før datainnsamlingen, samt god støtte og oppfølging både under og etter intervjuet. Forutsigbarhet ble blant annet ivaretatt ved at deltagerne fikk grundig informasjon om rammene for intervjuet; hvem de skulle snakke med, hvor lang tid det kom til å ta, og hvilke tema og typer spørsmål intervjuet inneholdt. De aller fleste av intervjuerne våre var helsepersonell med erfaring fra å snakke med mennesker i ulike grader av kriser. Vi mente derfor at de var godt egnet til å kunne ivareta de berørte i en samtale om det dramatiske de hadde vært igjennom. Det er imidlertid en utfordring å skulle innhente informasjon på en relativt lik måte fra et stort antall personer og samtidig ivareta den enkelte deltagerens behov i intervjusituasjonen. Det var derfor viktig at intervjuerne var grundig opplært i gjennomføring av intervjuet på forhånd, slik at de kunne bruke sin samtalekompetanse fritt i intervjusituasjonen. Noen instrukser ble også gitt, for eksempel at intervjuerne skulle la deltagerne fortelle sin historie fritt, uten unødvendige avbrytelser, samt at det var viktig å gi deltagerne pauser ved behov. Vi var også opptatt av å prøve i så stor grad som mulig å bruke samme intervjuer(e) for hver deltager/familie på hvert intervjutidspunkt. På denne måten kunne informantene bli trygge på hvem de skulle snakke med, og de slapp å forholde seg til mange forskjellige forskere.

Helt fra starten av var vi også opptatt av å ha kontakt med og inkludere organisasjoner som representerte de direkte berørte i 
utformingen av studien. Vi kontaktet AUF og den nasjonale støttegruppen på et tidlig tidspunkt og informerte dem om studien; hva vi ønsket å spørre de berørte om, og hvordan vi ønsket å gå frem. På disse møtene fikk representantene muligheten til komme med innspill på hva de tenkte det var viktig at vi spurte om. Disse innspillene tok vi med i betraktning i planleggingen av studien.

\section{Udekkede hjelpebehov}

Ettersom vi gjennom denne studien kom i direkte kontakt med mange av de som hadde overlevd terroranslaget, og deres foreldre, hadde vi en unik mulighet til å fange opp et eventuelt udekket hjelpebehov blant de berørte, og hjelpe de som ønsket mer oppfølging til å få kontakt med hjelpeapparatet. Hver enkelt intervjuer fikk derfor ansvaret for å gjøre en vurdering på slutten av intervjuet med tanke på eventuelt udekkede hjelpebehov. Dersom et slikt behov ble avdekket, kunne intervjueren gi deltagerne informasjon om hvem de kunne ta kontakt med, for eksempel fastlegen eller kontaktpersonen sin, og eventuelt tilby seg å ringe etter noen dager for å høre hvordan det hadde gått. Alternativt kunne intervjueren tilby seg å ta kontakt med hjelpeapparatet for dem, hvis de heller ønsket det. På denne måten kunne studien bidra til å fange opp mennesker som hadde et udekket hjelpebehov, og bidra til å sikre oppfølgingen av den enkelte.

\section{Hvordan kan vi ivareta intervjuerne?}

Forskere kan oppleve sterke følelser og reaksjoner når de blir eksponert for informantenes traumehistorier. Dette har reist spørsmål om muligheten for vikarierende traumatisering, hvilket innebærer forstyrrende og smertefulle traumerelaterte plager som følge av å lytte 
til andre menneskers detaljerte beskrivelser av tragedier og grusomheter (McCann \& Pearlman 1990). Prosjektledere har et etisk ansvar for å tenke på helsen og velferden til sine ansatte. Den internasjonale traumeforskningsorganisasjonen ISTSS (International Society for Traumatic Stress Studies) har laget retningslinjer som sier at ledere bør ha en etisk plikt til å fremme selvomsorg og veiledning for sine ansatte (Newman 2005). Noen av forslagene for å få til dette er at forskerne jobber i team, kun jobber et begrenset antall timer om gangen, kan melde fra om reaksjoner til prosjektledelsen, at prosjektledere setter av tid på forskningsmøter til å snakke om reaksjoner forskerne kan ha hatt etter intervjuene, og å snakke om egenomsorg for intervjuere.

I Utøya-studien hadde vi flere utfordringer knyttet til ivaretagelse av intervjuerne våre: De var mange, og de var geografisk spredt over hele landet. Videre var terroranslaget på Utøya en nasjonal tragedie som ikke bare påvirket de direkte berørte, men hele den norske befolkningen (Thoresen, Aakvaag, WentzelLarsen, Dyb \& Hjemdal 2012). Det betyr at intervjuerne kunne føle seg personlig berørt av hendelsen. Vi visste også at intervjuerne skulle få høre mange sterke historier, og vi var opptatt av at de ikke skulle bli sittende alene med eventuelle reaksjoner de fikk i ettertid. Intervjuerne arbeidet derfor mest mulig i team på to, slik at de kunne støtte hverandre, og vi anbefalte at de ikke gjorde mer enn to intervjuer i løpet av en dag. I tillegg hadde vi en egen telefonlinje inn til prosjektet gjennom hele datainnsamlingen, som vi oppfordret dem til å bruke ved behov. Vi arrangerte også et webbasert seminar om vikarierende traumatisering, med en amerikansk ekspert på feltet, for de intervjuerne som ønsket det. Etter hver intervjurunde arrangerte vi et oppsummeringsseminar der intervjuerne fikk høre noen foreløpige resultater fra prosjektet, samt fikk muligheten til å dele sine erfaringer som intervjuer. 


\section{Formidling av resultatene}

Hensikten med forskning er at kunnskapen vi fremskaffer, skal komme både berørte enkeltindivider og samfunnet som helhet til gode. For at dette skal kunne skje, må resultatene formidles og kunnskapen spres. Etter 22. juli var medienes interesse for hvordan det gikk med de som overlevde på Utøya, enorm, og vi visste at resultater fra studien ville få stor oppmerksomhet. Dette betød at vi hadde en unik mulighet ikke bare til å nå ut til helsemyndighetene med resultatene våre, men også til store deler av befolkningen. Samtidig betød dette at vi måtte være spesielt oppmerksomme på hvordan vi formidlet funnene våre. Én forskningsetisk utfordring her var at når resultatene ble gjort kjent, kunne det gå utover en av grunnpilarene i forskning, nemlig deltakernes konfidensialitet. De som deltok i Utøya-studien, var i stor grad allerede kjente fjes fra mediene: Omkring fire av fem av de som deltok, hadde på et eller annet tidspunkt etter 22. juli vært intervjuet eller hadde ytret seg i mediene (Thoresen, Jensen \& Dyb 2014). Det var følgelig en spesielt stor risiko for at sitater fra studien kunne spores tilbake til enkeltpersoner. Noe av det vi måtte gjøre for å sørge for at den enkelte deltagers konfidensialitet ble ivaretatt, var å endre deltagernes alder og/eller kjønn, i tillegg til at all annen informasjon som potensielt kunne identifisere dem, for eksempel stedsnavn eller omtale av andre med navn, ble fjernet eller omskrevet.

En annen utfordring vi hadde, var at de direkte berørte er en spesielt identifiserbar gruppe i det norske samfunnet. Dette stilte ekstra krav til oss når vi skulle formidle resultatene våre, og vi måtte veie våre ord godt. Selv om andre ikke ville kunne vite akkurat hvem som hadde sagt hva, ville mange vite hvem som var på Utøya 22. juli, og/eller hvem som var foreldre til de som overlevde. Når vi presenterer funnene våre, må vi ha dette i mente. Informantene har valgt å dele sine erfaringer med oss. Denne informasjonen skal vi 
forvalte forsvarlig og med respekt, og vi må gjøre det vi kan for å forhindre at vår forskning bidrar til en stigmatisering av de berørte og deres familier. I tillegg måtte vi tenkte over hvordan vi kunne minske informantenes potensielle ubehag knyttet til det å bli minnet på hendelsen, og det at de som gruppe igjen ville bli eksponert i mediene. Vi vet at det å være forberedt kan gi en opplevelse av kontroll i denne sammenheng. Før vi gikk ut med resultatene fra studien, var vi derfor opptatt av å dele dem med informantene våre først. Vi laget en avtale med støttegruppen om at de skulle få informasjon noen dager før nye funn fra studien ble publisert i mediene, og etter hver datainnsamling sendte vi ut en oppsummeringsrapport til alle deltagerne, med noen utvalgte resultater. På denne måten ønsket vi både å gi noe av kunnskapen studien hadde fremskaffet, tilbake til deltagerne våre, og vi ville forberede dem på hva som eventuelt kunne komme i mediene. Dermed slapp de at avisoppslag om studien kom helt overraskende på dem, og de kunne forberede seg på henvendelser fra pressen i forbindelse med funnene fra studien.

\section{NKVTS' oppdrag og deling av data fra terrorforskningen}

Som nasjonalt kunnskapssenter har NKVTS som mandat både å drive forskning og kunnskapsutvikling og å gi råd til myndighetene innenfor temaområdet vold og traumatisk stress. I tråd med dette og Nasjonal helseberedskapsplan (2014) bistod NKVTS myndighetene med en rekke oppgaver etter 22. juli. I den akutte fasen bisto NKVTS myndighetene med blant annet utforming av oppfølgingstiltak i helse- og omsorgstjenestene, rådgivning om tilbakereiser til Utøya, markeringer i Oslo og opplæring av helsepersonell i traumespesifikke tiltak. NKVTS ble også bedt om å lage et forslag til 
forskningsprogram knyttet til 22. juli-terroren. Utøya-studien inngår i dette programmet og er en av tre studier NKVTS utførte på oppdrag fra Helsedirektoratet etter at andre oppgaver knyttet til katastrofen var gjennomført. I det omfattende arbeidet NKVTS nedla etter terrorangrepet, er det to forhold som kan ha forskningsetisk interesse: 1) samarbeid med andre forskere om data innhentet i prosjektene, og 2) uavhengighet i forskningen i forhold til oppdragsgiver og andre oppgaver senteret utførte.

Hendelsene på Utøya og i regjeringskvartalet er av nasjonal og internasjonal interesse, og flere forskningsmiljøer ønsket å gjennomføre forskning knyttet til hendelsene. Som en følge av dette, og for å skjerme de overlevende fra å få for mange ulike henvendelser, opprettet Helsedirektoratet et koordineringsorgan for å håndtere samarbeidet mellom organisasjoner og forskningsinstitusjoner (se kapittel 1). Ledelsen i NKVTS har i hele perioden deltatt i dette koordineringsarbeidet og levert flere innspill underveis (De nasjonale forskningsetiske komiteene, sluttrapport frå koordineringsgruppa for 22. juli-forsking, 2014).

Som ansvarlige for Utøya-studien ble vi kontaktet av flere forskningsmiljøer underveis i prosjektet. Det ble lagt ned en stor innsats for å skape gode samarbeidsforhold med forskere som har ønsket det. Arbeidet har ført til deling av data med samarbeidspartnere ved Oslo Universitetssykehus, Sunnaas Sykehus, og Politihøgskolen, noe Regional komite for medisinsk og helsefaglig forskningsetikk (REK) har gitt tillatelse til. Tilbud om samarbeid ble også gitt til Høyskolen i Narvik og Universitetet i Oslo, men dette har ikke blitt realisert.

Det er en stadig økende tendens innen forskningen at data deles mellom forskningsmiljøer, særlig i større studier der det er gitt såkalt «bredt samtykke». På denne måten kan flere forskere bruke innsamlede data til å belyse ulike problemstillinger. Samtykkeerklæringene er da bredt formulert og det er spesifisert at data kan utleveres til andre forskergrupper. Typiske studier som bruker «bredt samtykke» 
er større helseundersøkelser som for eksempel Helseundersøkelsen i Nord-Trøndelag (HUNT) og Den norske mor og barn-undersøkelsen $(\mathrm{MoBa})$ ved Folkehelseinstituttet. Disse undersøkelsene inkluderer mange informanter og har et bredt folkehelseperspektiv for studien. Avidentifiserte data fra store grupper informanter kan på denne måten gi grunnlag for mange ulike studier, uten at det er fare for identifisering av personer eller at personvernet på andre måter trues.

I motsetning til denne typen studier hadde Utøya-studien et spesifikt formål om å kartlegge helse og andre psykososiale forhold hos en definert gruppe utsatte og pårørende i en begrenset periode. Deltagerne i studien hadde et spesielt behov for beskyttelse og personvern i gjennomføring av studien og utlevering av data. I tråd med regelverket for helsefaglig forskning (helseforskningsloven, 2008), er NKVTS forskningsansvarlig institusjon for Utøya-studien. REK la i sin behandling av prosjektet vekt på at deltagerne skulle motta god og oversiktlig informasjon om hva dataene skulle brukes til og hvem som hadde tilgang til dem. For eksempel ble det krevd spesifisert samtykke for kobling av data mot registre og journal. Det ble likevel åpnet for samarbeid med andre institusjoner om deling av data, så lenge dette foregikk innenfor gjeldende konsesjon og under forutsetning av at REK godkjente alle endringer i protokollen. Denne fremgangsmåten førte til at personvernet ble godt ivaretatt, samtidig som flere forskere fikk tilgang til data.

Utøya-studien har konsesjon til 2020, og er etter dette pålagt å slette eller anonymisere data, i tråd med retningslinjene etter andre katastrofer som for eksempel tsunami-katastrofen i 2004. Med vårt mandat som forskningsinstitusjon om vold og traumatisk stress ser vi klart nytten av å kunne oppbevare data i et lengre tidsperspektiv til ulike formål. Vi arbeider derfor med å muliggjøre dette gjennom opprettelsen av et forskningsregister. Slike registre er underlagt andre typer tillatelser enn typiske forskningsprosjekter. Informanter som 
deltar i ulike studier kan i tillegg til å samtykke til deltagelse i studien, gi tillatelse til at utvalgte data inkluderes i registeret. På denne måten kan informanter «donere» data til et register med et bredere formål enn typiske forskningsprosjekter, og dermed muliggjøre at deres data senere kan benyttes til ulike typer forsking.

NKVTS sitt oppdrag fra Helsedirektoratet ble nedfelt i et mandat om å utføre forskning som kartla helsetilstand og behov for helsehjelp over tid hos rammede etter katastrofen. Utover dette mandatet hadde ikke oppdragsgiver spesifikke krav til utførelse eller bruk av data, og NKVTS ble gitt stor tillit og frihet med tanke på bruk av metode og presentasjon av funn. Det er verken uvanlig eller nødvendigvis problematisk å forske på et materiale forskeren tidligere har jobbet med på andre måter, men som institusjon hadde vi høy bevissthet på at vi også hadde bistått myndighetene med en rekke oppgaver etter 22.juli. I forskningen vår har vi derfor ikke selv evaluert dette arbeidet. Det er evaluert av andre fagpersoner og omtalt i rapporten «Læring for bedre beredskap. Helseinnsatsen etter terrorhendelsene 22. juli 2011» utgitt av Helsedirektoratet (2012). Vårt mandat som forskere har ikke vært å evaluere hvordan kommuner eller helseforetak forholdt seg til de råd som ble gitt, eller om de syntes dette var nyttig og hjelpsomt for dem. Dette mandatet er gitt til konsulentselskapet Agenda Kaupang. I arbeidet med Utøyastudien har vi begrenset arbeidet til å dokumentere hvilken hjelp som faktisk ble gitt til de som overlevde på Utøya og deres foreldre. Her har vi gjort rede for at vi også deltok i arbeidet med å utvikle råd til kommunene om igangsetting av hjelpetiltak (se Dyb, Jensen, Glad, Nygaard \& Thoresen, 2014).

\section{Konklusjon}

Det å reflektere rundt den etiske forsvarligheten i forskningen vi gjør, er en nødvendig og nyttig øvelse. Vi møtte på mange etiske 
utfordringer i arbeidet med Utøya-studien, blant annet knyttet til deltagernes ekstreme eksponering, behovet for kyndige intervjuere, tidsaspektet, avgrensning av utvalget og rekruttering av deltagere. Vi har lært at det er mulig å utføre en studie med unge mennesker kort tid etter en så dramatisk hendelse, så fremt studien er godt planlagt og den blir utført på en forsvarlig måte. Det at de aller fleste av ungdommene og foreldrene som deltok i første intervjurunde, også valgte å delta i de to påfølgende rundene, tyder på at de syntes studien var viktig, og at nytteverdien veide sterkere enn det eventuelle ubehaget studien medførte. Vi håper at våre refleksjoner rundt de etiske dilemmaene vi møtte på i arbeidet med denne studien, kan være til nytte for andre forskere i fremtidige studier med mennesker i en sårbar situasjon.

Utøya-prosjektet ønsker å takke alle som deltok $i$ studien.

\section{Referanser}

Carlson, E.B., Newman, E., Walker Daniels, J., Armstrong, J., Roth, D. \& Loewenstein, M.D. (2003). Distress in response to and perceived usefulness of trauma research interviews. Journal of Trauma and Dissociation, 4 (2), 131-142.

De nasjonale forskningsetiske komiteene (2015). Sluttrapport frå koordineringsgruppa for 22. juli-forsking. Oslo: De nasjonale forskningsetiske komiteene. https://www.etikkom.no/globalassets/ sluttrapport-koordineringsgruppa-for-22.-juli-forsking.pdf

Dyregrov, K. (2004). Bereaved parents' experience of research participation. Social Science and Medicine, 58 (2), 413-426.

Dyb, G., Jensen, T.K., Glad, K.A., Nygaard, E., Thoresen, S. (2014). Early outreach to survivors of the shootings in Norway on the 22nd of July 2011. European Journal of Psychotraumatology, 5, doi: 10.3402/ejpt. v5.23523

Nasjonal helseberedskapsplan (2014). Versjon 2.0 fastsatt 2. juni 2014. Retrieved August 12, 2016, from: https://www.regjeringen.no/no/ dokumenter/Nasjonal-helseberedskapsplan/id761213/ 
Galea, S., Nandi, A., Stuber, J., Gold, J., Acierno, R., Best, C.L., Bucuvalas, M., Rudenstine, S., Boscarino, J.A. \& Resnick, H. (2005). Participant reactions to survey research in the general population after terrorist attacks. Journal of Traumatic Stress, 18 (5), 461-465.

Gallagher, M. (2009). Ethics. I: Tisdall, E.K., Davis, J. \& Gallagher, M. (Red.). Researching with children and young people: Research design, method and analysis. London: SAGE Publications.

Glad, K.A., Jensen, T.K. \& Dyb, G. (2014). «Er det hjelp du har savnet etter terroranslaget på Utøya?»: Foreldrene forteller. Tidsskrift for Norsk psykologforening, 51 (7), 537-545.

Helsedirektorartet (2012). Læring for bedre beredskap - Helseinnsatsen etter terrorhendelsene 22. juli 2011. IS-1984. ISBN-nr. 978-82-8081-256-8.

Helseforskningsloven (2008). Lov om medisinsk og helsefaglig forskning. Jensen, T.K., Dyb, G., Hafstad, G.S., Nygaard, E. \& Lindgaard, C.V. (2008). Tsunamien: Berørte barn og deres familier. Oslo: NKVTS. (Rapport nr. 4/2008.)

Kassam-Adams, N. \& Newman, E. (2005). Child and parent reactions to participation in clinical research. General Hospital Psychiatry, 27 (1), 29-35.

McCann, L. \& Pearlman, L.A. (1990). Vicarious traumatization: a framework for understanding the psychological effects of working with victims. Journal of Traumatic Stress, 3 (1), 131-149.

Newman, E., \& Kaloupek, D. (2005). Overview of research addressing ethical dimensions of participation in traumatic stress studies: autonomy and beneficence. Journal of Traumatic Stress, 22 (6), 595-602.

Newman, E., Risch, E. \& Kassam-Adams, N. (2006). Ethical issues in trauma-related research: a review. Journal of Empirical Research on Human Research Ethics, 1 (3), 29-46.

Newman, E., Walker, E.A., \& Gefland, R.N. (1999). Assessing the ethical costs and benefits of trauma-focused research. General Hospital Psychiatry, 21 (3), 187-196.

Ruzek, J.I. \& Zatzick, D.F. (2000). Ethical considerations in research participation among acutely injured trauma survivors: an empirical investigation. General Hospital Psychiatry, 22 (1), 27-36. 
Thoresen, S. Aakvaag, H.F., Wentzel-Larsen, T., Dyb, G. \& Hjemdal, O.K. (2012). The day Norway cried: Proximity and distress in Norwegian citizens following the 22nd July 2011 terrorist attacks in Oslo and on Utøya Island. European Journal of Psychotraumatology, 3, 1-11.

Thoresen, S., Jensen, T.K. \& Dyb, G. (2014). Media participation and mental health in terrorist attack survivors. Journal of Traumatic Stress, 27 (6), 639-646. 


\section{KAPITTEL 4}

\section{Etterlatte og sårbare grupper etter traumatiske tap}

\section{Kari Dyregrov ${ }^{1}$}

The chapter reports from a 3.5-year longitudinal study of close bereaved who lost their children, siblings, partners, parents and close friends in the terror shootings at Utøya, Norway July 22nd 2011. The study used mixed-methods and obtained quantitative and qualitative data from the bereaved. Questionnaires were collected at three time points ( $\left.\mathrm{T}_{1}-\mathrm{T}_{2}-\mathrm{T}_{3}\right)$; i.e. 18, 28 and 40 months after the killings $(\mathrm{N}=221)$, whereas in-depth interviews were conducted with 57 close bereaved at $\mathrm{T}_{2}$. Despite extensive help measures from the authorities, the results showed that the bereaved struggled with grief and trauma reactions more than three years after the event, and had slower reduction on scores than expected. Daily functioning at school and work was seriously affected, and 3.5 years after the terror, half of the parents had not retrieved the same work capacity as before the terror. Based on comprehensive previous research on vulnerable populations and research participation, the research group strongly emphasized ethical aspects to protect the 
bereaved in the study. As discussed in the chapter, the researchers and Ethical Board had a lengthy discussion and disagreement about what grieving people can tolerate and even want in connection to research participation. To solve serious disagreements and avoid losing time in costly projects, researchers should have the possibility to meet with EB, and arguments from both parts should be based on research and knowledge concerning research participation with vulnerable groups.

\section{Innledning}

Dette kapitlet omhandler forskningsprosjektet over etterlatte etter drapene på Utøya 22. juli 2011 («Etterlattestudien»), som ble igangsatt ved Senter for Krisepsykologi i Bergen. I tillegg til å gi en kort presentasjon av design, resultat og hovedfunn skal jeg løfte frem og diskutere noen forskningsetiske spørsmål og vurderinger. Spesielt vil jeg problematisere utfordringene som oppsto i forbindelse med søknad om godkjenning fra Regionale komiteer for medisinsk og helsefaglig forskningsetikk (REK).

Vår egen og andres forskning har vist at det er høy forekomst av angst, depresjon, traumereaksjoner og kompliserte sorgreaksjoner hos nære etterlatte etter brå uventet død (Dyregrov 2003; Kristensen, Weisæth \& Heir 2012). Når dødsfallene er påførte og voldelige, medfører det ytterligere økt risiko for kompliserte sorgforløp med nedsatt fungering (Keesee, Currier \& Neimeyer 2008; Neria mfl. 2007; Norris 2007).

Et overordnet mål for «Etterlattestudien» var å skaffe kunnskap om forhold som innvirker (positivt og negativt) på ulike grupper etterlattes psykososiale situasjon over tid, for å vurdere og foreslå tiltak for disse etterlatte og lignende grupper for fremtiden. Forskningsresultatene er publisert andre steder, og jeg vil her fokusere på forskningsetiske aspekter.

Vi har undersøkt etterlattes nivå av psykologisk stress og traume- og sorgreaksjoner etter terroren, for å se om, og eventuelt hvordan, 
det påvirker skoleprestasjoner, arbeidsfunksjon og sosialt liv (Dyregrov, Dyregrov \& Kristensen 2014a; Dyregrov \& Kristensen 2015; Johnsen, Laberg, Matthiesen, Dyregrov \& Dyregrov 2015). Videre har vi studert hvilket offentlig hjelpetilbud etterlatte har fătt, og om det tilfredsstiller føringene i den proaktive modellen og etterlattes behov for hjelp (Dyregrov, Kristensen \& Johnsen 2014b). Vi har også sett på etterlattes mestring, og støtte fra sosiale nettverk og andre etterlatte (Dyregrov, Kristensen \& Dyregrov 2016).

Prosjektperioden var fra 2012 til medio 2016, og studien var en langtidsstudie med datainnsamling $\left(\mathrm{T}_{1}, \mathrm{~T}_{2}\right.$ og $\left.\mathrm{T}_{3}\right)$ henholdsvis 18 , 28, og 40 måneder etter terroren (januar 2013, november 2013 og november 2014). Studien er godkjent av REK sør-øst.

\section{Forskningsmetode}

Studien kombinerte kvantitative og kvalitative metoder, og et utforskende og fenomenologisk perspektiv, der forskningsdeltakerne på ulike måter ble hørt, var sentralt for de forskningsmetodene som ble valgt.

Rekruttering av nærmeste foreldre og søsken skjedde gjennom kobling mellom offentlige navnelister over de som ble drept på Utøya, og folkeregisteret. Foreldre og søsken ble kontaktet via informasjonsskriv der de ble spurt om å delta i prosjektet og om å bidra til å rekruttere fire til seks av avdødes nære venner til prosjektet. Informantene ble informert om at dersom vi ikke hørte noe fra dem, ville vi skriftlig kontakte dem på nytt to-tre uker etter at informasjonsbrevet ble sendt ut. Etter skriftlig informert samtykke fra alle informantgrupper fikk de tilsendt spørreskjema. Forespørselen og samtykket gjaldt også mulig intervjudeltakelse. Rekruttering ble satt i gang etter REK-godkjenning og sikret finansiering.

De som har deltatt i studien, er 86 foreldre, 43 søsken, 2 partnere, 1 barn og 89 nære venner. Disse representerte 66 avdøde som 
ble inkludert i studien. Svarprosenten for biologiske foreldre var 63 prosent, med 7 steforeldre i tillegg. Totalt var 79 prosent av de avdøde representert med en eller flere etterlattegrupper.

Det ble innhentet omfattende spørreskjema- og dybdeintervjudata fra deltakerne. For de yngste søsknene i aldersgruppen 12-15 år ble data innhentet ved strukturerte intervju. Spørreskjema ble brukt for å innhente opplysninger om sorgbearbeiding og forløp, funksjon i arbeid og skole, mestringsstrategier og hjelp via nettverk, andre etterlatte og hjelpeapparatet. Vi dybdeintervjuet 22 foreldre, 19 søsken, 13 venner, to partnere og ett barn for å gi prosess- og dybdeforståelse av kvantifiserbare spørsmål fra spørreskjema. Metoden ble valgt for at de etterlatte med egne ord skulle få uttrykke sine opplevelser, tanker og erfaringer knyttet til den unike konteksten de hørte hjemme i. Forskerne var også opptatt av mulighetene for å fremskaffe genuint ny kunnskap gjennom å la informanten styre tankerekker og resonnement i dybdeintervjuet. Den direkte kontakten med informanten gjennom å møte ham eller henne anså vi som en klar fordel med hensyn til å kunne mobilisere eventuelle behov for hjelp. Dybdeintervjuene ble gjennomført i eller nær hjemmet tilpasset etterlattes ønsker, tatt opp på bånd og skrevet ut i sin helhet. De kvalitative dataene ble analysert ved fortolkende fenomenologisk metode og tematisk innholdsanalyse (Kvale 1996; Smith, Flowers \& Larkin 2009).

\section{Hovedfunn i studien}

Her skal jeg kort skissere noen av hovedfunnene fra «Etterlattestudien», og jeg henviser underveis til andre artikler for mer omfattende og etterprøvbare publikasjoner av resultatene. Alle gruppene etterlatte hadde store psykososiale vansker på første datainnsamling, som viste seg gjennom høye skårer på mål på komplisert sorg, traumereaksjoner og psykologiske stressreaksjoner (Dyregrov 
mfl. 2014a; Dyregrov \& Kristensen 2015). Det har vært en viss bedring for alle gruppene over tid, størst fremgang for nære venner. Skole- og arbeidsfungering har også bedret seg noe over tid, og mest for menn. Etter tre og et halvt år slet likevel svært mange fortsatt. Mens 69 prosent kvinner og 54 prosent menn hadde nivå for «komplisert sorg», lå 71 prosent mødre og 61 prosent fedre over den kliniske grensen for mulig PTSD, noe som går utover daglig fungering i arbeid, skole og sosialt liv (Dyregrov \& Kristensen 2015).

Dybdeanalyser viste imidlertid variasjon innenfor gjennomsnittene for de ulike gruppene, og at en mindre gruppe foreldre, venner og søsken greide seg svært bra. Vi fant en saktere nedgang på sorg- og stressreaksjoner for foreldre (Dyregrov \& Kristensen 2015) enn for de andre gruppene (Dyregrov, Kristensen \& Johnsen 2015). Mødre opplevde størst funksjonstap knyttet til arbeid utenfor hjemmet i tillegg til svekket deltakelse i sosialt liv, mens fedre opplevde de største vanskene med deltakelse i sosialt liv og dernest jobb. Jenter og kvinner i de ulike gruppene rapporterte generelt mer plager enn gutter/menn.

En annen alvorlig følge av terrordrapene var at mange foreldre tre og et halvt år etter 22. juli 2011 fortsatt ikke var tilbake i jobb på samme nivå som før drapene. Halvparten av foreldrene var helt eller delvis ute av jobb (sykmelding, avklaring, uføretrygd), betydelig flere mødre (63 prosent) enn fedre ( 35 prosent). Men det var store bevegelser, slik at andelen personer som var sykmeldte, på avklaringspenger eller delvis i jobb, varierte over tid (Dyregrov \& Kristensen 2015).

Halvparten av søsknene opplevde at hendelsen påvirket deres skoleprestasjoner i negativ forstand, i form av karakternedgang og fravær fra skolen. Konsentrasjons- og innlæringsvansker og manglende motivasjon var med på å forklare dette. I tråd med tidligere forskning oppga en stor andel av foreldre/partnere (82 prosent), 
søsken/barn (75 prosent), og nære venner (79 prosent) at de i betydelig grad hadde fătt endrede verdier og endret opplevelse av hva som var viktig i livet (Dyregrov mfl. 2015).

Gjennom dybdeintervjuene utdypet de etterlatte at de ønsket seg tilbake til en hverdag preget av mindre smerte, samtidig som de uttrykte at de ønsket å glemme det som hadde skjedd, og spesielt gjerningsmannen, men aldri den de mistet. Dette uttrykkes av en mor som mistet sin 18-åring på Utøya:

Jeg prøver å ikke bruke energi på ham $(A B B)$... det er en jeg skal bruke energi på og minnes, og det er Fredrik², og det er, da må jeg snakke om ham ... jeg vil jo at Fredrik skal leve videre selv om han ikke er her på jorda.

De etterlatte mobiliserte store ressurser og brukte mange ulike mestringsstrategier for å ta seg videre i livet. Hovedmestringen skjedde via mobilisering av kognitive refleksjoner og tenkemåter, proaktive og konfronterende aktiviteter, unngåelse og beskyttende handlinger og økte mestringsressurser ved hjelp av fagfolk, andre i samme situasjon (likemenn) og sosiale nettverk (Dyregrov mfl. 2016). En mor som mistet sin 15-åring på Utøya, reflekterer rundt sine mestringsmåter:

Jeg har vært fysisk aktiv, det har vært viktig. Og så har jeg klart å holde kontakt med arbeidsplassen min og vært sånn delvis på jobb nesten hele tiden ... Og så har jeg jo ... snakket om og vært åpen om det som har skjedd, og sagt hva jeg har trengt, og takket ja til de tilbudene som har kommet, selv om jeg kanskje ikke har hatt lyst. ... Og i forhold til sånne sosiale ting så har jeg kanskje kjent at, åh, bare orker ikke, men så har jeg en liten stund vært med, og så har det liksom vært litt sånn positivt. Støtten fra nærmiljøet vårt den har jeg

2 Navn på avdød er fiktivt/anonymisert. 
tatt imot, da, selv om det også har vært en utfordring å være en som trenger hjelp ... men jeg har jo trengt det.

I sin kamp for å gå videre med livet var støtten fra sosiale nettverk særdeles viktig. Etter tre og et halvt år hadde naturlig nok denne støtten avtatt, selv om de etterlatte ønsket at de omkring hadde et lengre tidsperspektiv på sorg.

Tidlig besluttet helsemyndighetene å gjennomføre en proaktiv hjelpemodell fra kommunene med tidlig oppfølging for de etterlatte. Hver familie skulle bli kontaktet, fa en koordinator som holdt kontakt med dem gjennom det første året, og hjelpen skulle være tilpasset den enkeltes og familiens behov (Helsedirektoratet 2011). I tillegg ble nære familiemedlemmer tilbudt fire helgesamlinger på Gardermoen 4, 8, 12 og 18 måneder etter terroren, der likemannsstøtte fra andre etterlatte og psykologisk undervisning fra fagfolk ble vektlagt (Dyregrov, Dyregrov, Straume \& Bugge 2014c). Videre ble det tilrettelagt flere besøk til Utøya der etterlatte ble ledsaget av og fikk faktainformasjon fra relevante grupper fagfolk. Nasjonal støttegruppe etter 22. juli-hendelsene ble tidlig dannet til støtte for etterlatte og overlevende. For å avhjelpe utfordringer overfor unge etterlatte og overlevende i skolen holdt myndighetene to helgesamlinger med informasjon for skoleeiere og lærere. Den store hjelpeinnsatsen resulterte $\mathrm{i}$ at foreldre og søsken var meget tilfredse (75 prosent) (Dyregrov mfl. 2014b) med oppfølgingen, og spesielt med de fire nasjonale helgesamlingene administrert fra Helsedirektoratet (95 prosent meget tilfredse) (Dyregrov mfl. 2014C). En mor som mistet et barn på 16 år, beskriver betydningen av samlingene slik:

For meg har det vært kjempeviktig. Det har vært så utrolig godt å få disse fellessamlingene og se de andre, snakke med dem og ... de gruppesamtalene har vært utrolig nyttige og viktige. Og så det som foregikk i plenum ... det har vært kjempeviktig, selv om det har vært 
kjempeslitsomt. Disse samlingene er utrolig viktige, og jeg er veldig takknemlig ... og jeg skulle ønske det var flere.

Det er nærliggende å spørre seg: Hva skyldes den sakte nedgangen og det høye symptomnivået etter tre og et halvt år? Hvorfor ser man så vidt høyt belastningsnivå, på tross av en meget god tilfredshet med oppfølging? Det er grunn til å anta at noe av forklaringen er at nære etterlatte, i tillegg til at de har lidt umistelige tap, har hatt en særdeles kraftig opplevelse med høy eksponering samt retraumatisering i tilknytning til hendelsen over tid. Det helt spesielle var at hendelsen resulterte i brutale drap på mange svært unge mennesker. En del data, spesielt fra intervjuene, kan tyde på at ikke alle etterlatte som har trengt det, har mottatt tilstrekkelig eller spesifikk sorg- og traumeterapeutisk hjelp. I tillegg kan det se ut til at deler av hjelpeapparatet og det sosiale nettverket har stoppet hjelpetiltak for tidlig, fordi det er vanskelig å forstå det lange tidsperspektivet på traumatisk sorg. Det er også grunner til å anta at en del etterlatte får sterke reaksjoner på et senere tidspunkt enn andre, delvis på grunn av at den private sorgen ble satt på vent av alt de måtte forholde seg til på samfunnsnivå (Dyregrov \& Kristensen 2016; Dyregrov mfl. 2016). Hvordan det vil gå videre, vet man ikke om man ikke følger de etterlatte i nye studier over tid. Vil vi se en videre nedgang av symptomer og bedring av psykisk, fysisk og sosial fungering?

\section{Forskningsetiske hensyn}

Senter for Krisepsykologi har siden 1988 gjennomført en rekke studier på sørgende og traumatiserte grupper. Her har ivaretakelse av etterlatte gjennom forskningsprosessen alltid stått sentralt. Disse erfaringene ble benyttet for å nærme seg de etterlatte etter Utøyadrapene på en sensitiv og skånsom måte, og for å vise ydmykhet og 
respekt for de sårbare unge og voksne i krise. Vi fulgte våre tidligere rutiner for etisk, herunder personvernmessig, ivaretakelse. Vår erfaring tilsier at man ikke skal unnlate å forske på etterlatte ved unaturlig død, men at forskningen skal gjøres med nærhet og empati av erfarne forskere med kompetanse på fagfeltet. Egne (Dyregrov \& Dyregrov 2000; Dyregrov 2004; Dyregrov, Dieserud, Straiton, Rasmussen, Hjelmeland \& Knizek 2010-2011) og andres studier (Cook 2001; Cook \& Bosley 1995; Jorm, Kelly \& Morgan 2007; Kentish-Barnes mfl. 2015; Legerski \& Bunnell 2010; Omerov, Steineck, Dyregrov, Runeson \& Nyberg 2013) har vist at selv om det også kan være vondt å bli kontaktet angående en smertefull hendelse som å ha mistet noen, så er ulike rammede grupper svært opptatt av at andre skal lære fra deres situasjon. Det verste har allerede skjedd dem.

Etterlatte opplever det som meningsfylt å delta i forskning, og de aller fleste rapporterer at de i ettertid ikke angrer fordi det gir en form for mestring og mening til det meningsløse dersom de kan hjelpe andre. Etterlatte har gjennom ulike forskningsprosjekt opplevd det som spesielt verdifullt å delta i dybdeintervju sammenliknet med deltakelse i spørreskjemaundersøkelser. Et stort flertall rapporterer om en læringseffekt, at det er givende og har en «terapeutisk effekt» å delta i kvalitative dybdeintervju der man får gjennomgå hendelsen på nytt sammen med en fagperson med kompetanse på feltet. Man får fortelle «hele historien» og fritt assosiere til det som er viktigst for en selv i en selvvalgt og naturlig sammenheng både med hensyn til innhold og kontekst (dvs. hjemme hos seg selv) (Dyregrov \& Dyregrov 2000; Dyregrov 2004; Dyregrov mfl. 2010-2011; Dyregrov, Dieserud, Hjelmeland, Straiton, Rasmussen, Knizek \& Leenaars 2011). Tilbakemeldingene fra sårbare grupper som har fylt ut standardiserte spørreskjema, er at ikke alle spørsmål alltid passer. Man finner ikke nødvendigvis passende kategorier for gradering av spørsmålene, eller de opplever at de ikke blir spurt om viktige spørsmål/temaer. 
Vi vektla å møte de etterlatte varsomt og taktfullt gjennom forskningsprosessen. Gjennom tilsendte informasjonsskriv forut for intervjuet ble barn/unge og voksne grundig informert om sine rettigheter og om prosjektets oppdragsgiver, hensikt og gjennomføring. Alle krav til anonymitet og konfidensialitet fulgte Helsinkideklarasjonen, og informantene ble eksplisitt informert om sin rett til når som helst å kunne trekke seg fra prosjektet. For å tilpasse informasjonen til alders- og modningsnivå ble det utarbeidet separate skriv til de ulike etterlattegruppene, og samtykkeskjema fulgte informasjonsskrivene. Et eget informasjonsskriv ble utarbeidet for søsken i aldersgruppen 12-16 år der foreldrene ble bedt om å gi sitt samtykke til disse barnas deltakelse. Dersom barn, unge eller foreldre hadde behov for ytterligere psykososial hjelp, tilbød senteret å bidra til kontakt med hjelpeapparatet på informantenes hjemsted. I informasjonsskrivene ble prosjektlederens navn og telefonnummer oppgitt, med oppfordring om at de etterlatte gjerne måtte kontakte prosjektlederen.

En prosedyreguide for forskerne for gjennomføring av dybdeintervjuene (tabell 1) ble utarbeidet for å sikre empatisk utspørring og trygghet i intervjusituasjonen, samt at etiske retningslinjer og forskningsmetodikk ble fulgt systematisk.

Prosedyreguiden og temaguiden for selve intervjuet ble utarbeidet og diskutert i prosjektgruppen forut for intervjuene. Før oppstart gjennomførte prosjektleder et "prøveintervju» med en reell informant/etterlatt, mens de to andre forskerne bivånet intervjuet i stillhet og i bakgrunnen. I etterkant diskuterte forskergruppen erfaringer fra dette intervjuet for å samkjøre forskningsmetodikk i kombinasjon med en individtilpasset og sensitiv fremgangsmåte. Ettersom et viktig prinsipp for åpne kvalitative intervju er at man skal kunne lære og forstå nye fenomen, vektla forskerne å stille åpne spørsmål knyttet til tema, la informanten 
Tabell 1 En prosedyreguide for forskerne for gjennomføring av dybdeintervjuene

\section{Før intervjuet}

1. Intervjuer gir en kort presentasjon av seg selv

2. Omtale kort og enkelt:

- all forskningsdeltakelse er frivillig

- prosjektets hovedmålsetting

- intervjuets form («samtaleintervju»)

- forsker og organisasjonene bak prosjektet

- godkjennelse fra etisk komité

- streng taushetsplikt

- alle opplysninger behandles strengt konfidensielt

- forholdsregler for anonymisering ved publikasjoner

- lydopptak / data slettes iht. REK

- intervju oppbevares på minnebrikke nedlåst i skap, ikke på datamaskin

- informanten kan når som helst trekke seg fra intervjusituasjonen uten negative konsekvenser og uten noen begrunnelse

3. «Ok å bruke lydopptaker gjennom intervjuet»

- «du kan be om å slå av opptaker underveis, og ta pauser ved behov»

Intervjuet (Opptaker settes på)

1. Temaguide for intervjuet følges mtp. tema - men ikke nødvendigvis i rekkefølge

2. Siste spørsmål: «Er det noe annet du ønsker å tilføye før vi avslutter intervjuet?» (Markere at intervjuet er ferdig)

\section{Etter intervjuet}

1. Oppsummerer intervjuet for å bekrefte informanten og viktigste informasjon

2. Stiller spørsmålet: "Hvordan var det for deg å snakke om dette nå?" (pos/neg) (Slå av opptaker)

3. Opplever informanten å ha tilstrekkelig hjelp i forhold til behov/det de sliter med? Kan vi hjelpe med noe?

4. OK evt. å bruke sitater anonymt i publikasjoner?

5. Støttegruppen 22. juli vil motta en kort rapport før resultatene offentliggjøres i vitenskapelige publikasjoner.

6. Intervjuer takker for deltakelse. Igjen understrekes at alt informanten har fortalt vil bli behandlet konfidensielt. 
snakke, og så følge opp spørsmål rundt det informantene opplevde som viktig.

Alle etterlatte fikk velge om de ønsket å bli intervjuet i sine hjem, eller eventuelt andre steder i nærheten. De fleste foreldrene valgte å bli intervjuet i sine hjem, mens en del unge også valgte andre steder, mest av praktiske grunner. Forskerne vektla å «være gjest» $\mathrm{i}$ informantenes hjem, i tillegg til å være forsker, og tok imot tilbud om å se album, bilder, avdødes rom, gravsteder etc. som etterlatte ønsket å vise. Videre takket forskerne ja til å være sammen med den enkelte informant/familien ved måltider eller uformell prat, for å bidra til å skape nødvendig trygghet og tillit før intervjuene. Dersom dette ikke ble foreslått av de etterlatte selv, tok forskerne selv initiativ til slik uformell prat. For å kunne møte de etterlatte med ro og uten tidspress innenfor de rammene som de selv ønsket å skape omkring intervjuet, ble det beregnet svært god tid for hvert intervju. Dette ble bemerket og verdsatt av mange. Ett intervju med lang reisetid kunne derfor ta mer enn et døgn, slik at forskerne reiste omkring i Norge i tre måneder.

Tre sorgforskere med variert bakgrunn (sosiolog/psykolog) og omfattende klinisk erfaring og forskningserfaring på traumatiserte etterlatte gjennomførte alle de 57 kvalitative intervjuene. Det ble ansett som svært viktig å ikke spre intervjuene på flere personer for å sikre samkjøring, kvalitet og konsistens for intervjumåte og innhold.

\section{Hvor mye tåler sårbare grupper?}

Det hender det oppstår uenighet og konflikt mellom forskere og etiske komiteer i vurderingene av hva og hvor mye sårbare grupper tåler. Fra den internasjonale litteraturen ser vi eksempler på at etiske komiteer ofte legger strengere begrensninger på slik forskning enn det forskerne vurderer som nødvendig. Forskere som 
studerer sårbare grupper, innvender at beskyttelsen skjer på bekostning av hva de etterlatte selv vil, og hva forskningsfeltet trenger. Forskere opplever også at etiske komiteer overvurderer den negative betydningen av forskningsdeltakelse, mens de positive sidene for deltakerne ikke tas i betraktning, med det resultat at viktig forskning forringes eller i verste fall forhindres (Jorm mfl. 2007; Legerski \& Bunnell 2010; Omerov mfl. 2013; Jaffe, DiLillo, Hoffman, Haikalis \& Dykstra 2015; Lakeman \& FitzGerald 2009).

Cook (2001) poengterte tidlig betydningen av at det må forskes på sårbare grupper for å lære fra dem hvordan man best kan tilrettelegge for forskning, og hevdet at gråt i intervjusituasjonen ofte ble feiltolket som at det var stressfullt og en negativ opplevelse å delta $\mathrm{i}$ forskning. I likhet med andre som har forsket på sårbare gruppers deltakelse i forskning, hevdet hun at forskningsdeltakelse tvert imot ofte ønskes velkommen og oppleves som hjelpsomt og «terapeutisk» (Dyregrov 2004; Dyregrov mfl. 2010-2011; Cook \& Bosley 1995; Omerov mfl. 2013). Det oppleves som meningsfylt i en situasjon som er preget av meningsløshet, å kunne hjelpe andre som kommer i en liknende situasjon, gjennom fremskaping av ny kunnskap. Videre er det mange som når det har gått noe tid, ikke lenger kan diskutere og ventilere sine tanker og følelser om tapet og det som har skjedd - dette får de mulighet til og innspill på gjennom for eksempel kvalitative dybdeintervju (Dyregrov mfl. 20102011). Svært få som har deltatt i sorgstudier av god kvalitet, angrer på slik deltakelse, men ville anbefale den for andre og tenker at det har vært positivt for dem selv og samfunnet (Dyregrov 2004; Cook \& Bosley 1995; Omerov mfl. 2013). I en norsk studie av 120 etterlatte foreldre etter selvmord, ulykker og krybbedød var det ingen som vurderte deltakelse som bare belastende, eller angret på forskningsdeltakelsen (Dyregrov 2004). I forskningslitteraturen finnes det med andre ord godt belegg for at det både er viktig og forsvarlig å involvere sårbare grupper i forskningsprosessen. 
For «Etterlattestudien» var behandlingen av prosjektsøknaden i REK en av de største utfordringene ved prosjektet. Vi ønsket å følge detaljerte protokoller for omsorg og ivaretakelse av de etterlatte etter 22. juli slik vi har gjort i prosjekter for sårbare grupper tidligere. Vi opplevde imidlertid at vi møtte argumenter og synspunkter som ikke stemte med egne erfaringer eller internasjonal litteratur om etterlattes opplevelse av forskningsdeltakelse, uten at komiteen underbygde sin egen argumentasjon med forskning.

For det første tillot ikke REK at man, i tillegg til å informere om mulige belastninger ved forskningsdeltakelse, fikk informere om de mulige positive følgene som er dokumentert overfor liknende grupper. Videre ble vår vanlige måte å henvende oss til rammede grupper på, gjennom å innlede informasjonsbrev med «kjære NN», også avvist. Begge avvisningene ble begrunnet med at tekst må utformes på en nøytral måte, i henhold til REKs mal. Argumentasjonen om å «bruke mal» og «ikke skulle bruke ladede og følelsesmessige uttrykk» opplevde vi som nokså paradoksal når man visste hvilken særskilt opplevelse og hvilket følelsesmessige kaos etterlatte etter Utøya terroren sto i. Vår vurdering var at språkbruk i henvendelsesmåte må tilpasses gruppen man henvender seg til - noe vi har god tilbakemelding og langvarig praksis på. Disse uenighetene valgte vi å se som mindre uenigheter der vi bøyde av.

Den viktigste uenigheten med REK dreide seg imidlertid om at prosjektgruppen ønsket å kunne kontakte etterlatte per telefon etter at de først hadde mottatt informasjon om prosjektet og invitasjon til å delta. Vi ønsket at tre erfarne sorgforskere skulle gjøre slik henvendelse ett og et halvt år etter terroren for å gi direkte informasjon og dermed flere sjansen til å delta i forskningen, men selvsagt uten på noen måte å presse dem til å delta. Vi vektla en skånsom «step-by-step approach» basert på tidligere kunnskap og dokumentasjon om forskning på sårbare grupper (Dyregrov 2004; Omerov mfl. 2013). Tilnærmingen innebærer at man tar en varslet 
telefon til de etterlatte etter informasjonsbrev i forkant, og går varsomt frem i samtalen (se tabell 2). Dette fikk vi ikke gjennomslag for på tross av at telefonkontakt ble godkjent i forbindelse med forskning på overlevende bare fire måneder etter 22. juli-terroren.

REKs begrunnelse for avslag for telefonhenvendelse var at «Komiteen finner at etterlatte etter Utøya er i en særdeles sårbar situasjon», uten at det ble oppgitt hvorfor de etterlatte skulle være så mye mer sårbare enn de overlevende (Referat: 2012/834/REK sør-øst D). Våre argumenter var at etterlatte har opplevd at det aller verste har

Tabell 2 Step-by-step approach for rekruttering via telefonkontakt

1. To av forskerne fra prosjektgruppen med særskilt kompetanse og erfaring fra å møte og forske på etterlatte vil ta telefonsamtalene. Begge har sine doktorarbeid på etterlatte ved traumatisk død.

2. Forskeren innleder med et generelt spørsmål og er svært lydhør med hensyn til om den etterlatte eventuelt ikke ønsker å snakke med forskeren. Enhver indikasjon på dette vil umiddelbart bli respektert og akseptert, og man vil ikke utfordre eller prøve å overtale den etterlatte til å delta. Samtalen avsluttes ved signaler om at den etterlatte ønsker det.

3. Der samtalen ikke avsluttes med en gang, fortsetter man telefonsamtalen med å spørre den etterlatte om han eller hun har lest informasjonsbrevet, og om han eller hun eventuelt har noen spørsmål.

4. Hvis informanten hverken avslår eller samtykker i å delta (noe som ofte er tilfellet), spør vi om de ønsker å få tilsendt et spørreskjema - noe han eller hun da svarer ja eller nei til.

5. Videre vektlegger forskeren at dersom man ønsker å delta i studien, så kan man trekke seg på ethvert tidspunkt i løpet av denne.

6. Dersom noen i løpet av samtalen kommer inn på sitt tap og uttrykker behov for hjelp, lytter forskeren til dem og tilbyr eventuelt å hjelpe i kontakt med relevante hjelpetiltak.

7. Ved slutten av hver samtale spør man om tillatelse til å ringe dersom ikke spørreskjema er innsendt innenfor den tidsrammen man er enige om.

8. Forskeren vil til slutt spørre: «Ønsker du at vi tar kontakt med deg og eventuelt hjelper deg i kontakt med hjelpeapparatet dersom vi av spørreskjemasvarene ser at du fortsatt sliter?» 
skjedd, og for mange kan det gi noe mening til det meningsløse å delta i forskning. Vår erfaring er også at mennesker som har opplevd slike hendelser, vet svært godt hva de vil og ikke, og er i stand til å uttrykke det dersom de får respektfulle og hensyntakende forespørsler om forskningsdeltakelse. Vi underbygde synspunktene våre med referanser til forskning, mens vi aldri mottok tilsvarende referanser fra REK som underbygde deres synspunkter i saken.

Etter åtte måneders svært energikrevende saksgang med REK sør-øst fikk vi i vår klage til Den nasjonale forskningsetiske komité for medisin og helsefag (NEM) støtte for at vår fremgangsmåte var forsvarlig. ${ }^{3}$ NEM omgjorde REKs vedtak, og godkjente bruk av vår foreslåtte «step-by-step approach». Dessverre kom avgjørelsen så sent at vi fikk denne muligheten bare for vår siste datainnsamling ( $\mathrm{T}_{3}$ ), og ikke de to foregående ( $\mathrm{T}_{1} \mathrm{og} \mathrm{T}_{2}$ ). Slik vi ser det, resulterte uenighetene mellom forskergruppen og REK $i$ at vi trolig fikk færre informanter enn vi kunne hatt med på $\mathrm{T}_{1} \mathrm{og} \mathrm{T} 2$, prosjektet ble forsinket og tappet prosjektgruppen for krefter og fokus på den videre forskningsprosessen.

Erfaringene fra telefonsamtalene med etterlatte på $\mathrm{T}_{3}$ var at de $\mathrm{i}$ høyeste grad ble verdsatt av de etterlatte. De satte pris på å bli kontaktet, og at de også fikk sjanse til å ta opp andre ting enn forskningsdeltakelse - blant annet mulige hjelpetiltak. Gjennom vår kontakt med de etterlatte fikk vi bekreftet vanlige grunner til at rene postale undersøkelser kan gi begrensninger på svarprosent som ikke skyldes manglende ønske om å delta. Vi fikk vite at spørreskjema på $\mathrm{T}_{1}$ og $\mathrm{T}_{2}$ ikke hadde blitt innsendt fordi de hadde: a) glemt at de hadde fått skjema, b) fylt ut skjema, men glemt å sende det, c) fått ny adresse (spesielt unge) og dermed ikke mottatt skjema, d) trodd $\mathrm{T}_{2}$ var purring på $\mathrm{T} 1$ og kastet skjema fordi de

3 Se NEMs vedtak i saken her: https://www.etikkom.no/hvem-er-vi-og-hva-gjor-vi/ komiteenes-arbeid/Uttalelser/NEM/Etterlatte-foreldre-sosken-og-venner-etter227-Saksnr-2013160/(nedlastet 16.08.16) 
visste at de hadde svart på T1, e) ikke mottatt skjema fordi det gikk i spamfilter (et problem for digitale skjema til bl.a. Hotmailadresser), f) hatt liten tid, g) hatt vansker med å forstå alle spørsmålene, eller at noen spørsmål opplevdes som lite relevante. Når vi gjennom intervjuene fikk vite at de fleste har konsentrasjonsvansker i betydelig grad, er punktene a-g forståelige - men desto viktigere er det at forskere får sjansen til direktekontakt med etterlatte. I tillegg ser vi at innvandrerfamilier er underrepresentert i undersøkelsen fordi vi ikke hadde mulighet til å undersøke om de ville ha trengt tolkehjelp for å forstå informasjonsbrevene eller spørsmålene i spørreskjemaene godt nok. Vi antar således at det var barrierer som en telefonkontakt på T1 og $\mathrm{T}_{2}$ hadde kunnet bøte på.

\section{Avslutning}

Etter å ha gjennomført et omfattende forskningsprosjekt på sårbare grupper, de som mistet sine nærmeste ved terroren på Utøya 22. juli 2011, har vi igjen fått bekreftet hvor viktig forskning på de etterlatte er. Sammen med de etterlatte, og på vegne av dem, kan forskning bidra til at samfunnet får høre hvordan de selv opplever at de har det, hvilken hjelp de har fått og trenger, og hvordan de kan mestre å gå videre med livet. Dette kan bidra til økt forståelse og støtte fra hjelpere og lokalsamfunn, og bidra til økt mestring hos de etterlatte. Kunnskapen kan også bidra til å at nye etterlatte fra kommende katastrofer kan få enda bedre støtte og hjelp, noe som er en viktig motivasjon for mange etterlattes forskningsdeltakelse. Forskning på sårbare grupper må imidlertid følge strenge etiske regler, basert på vurderinger og kunnskap som etiske råd, forskere og rammede har akkumulert både nasjonalt og internasjonalt. Som vist i dette kapitlet kan det også oppstå uenigheter knyttet til slike vurderinger. Ved å formidle disse kan man lære fra dem og ta slike problemstillinger et steg videre. 
Det vil være ønskelig at REK og forskere har en mer aktiv og nær dialog ved uenighet, spesielt på nisjefelt (f.eks. etterlatte/sorg og traumer). Når partene står langt fra hverandre, bør partene møtes med mål om å skape konsensus. Nærmere kontakt mellom etiske komiteer og forskere vil således kunne bidra til at disputter kan løses raskt slik at kostbare forskningsprosjekt ikke mister tid. Argumenter og motargumenter i saker og ankesaker bør baseres på faglig dokumentasjon, og ikke utelukkende på etiske og moralske standpunkt. Videre bør forskere få tillatelse av REK til å gi sårbare grupper opplysninger om andres positive opplevelser av forskningsdeltakelse («brukererfaringer») som dokumentert gjennom forskning, og ikke bare pålegges å opplyse om potensielle farer.

Til slutt bør det poengteres at REK har en avgjørende rolle i å sikre at etiske hensyn er ivaretatt i møte med sårbare grupper, slik at det ikke gjøres skade ved forskning. Forskere på sin side må kunne stole på at beskyttelse av slike grupper er basert på og belagt med faglige argumenter, og at det er transparens rundt komiteenes vurderinger. Vi trenger solid og valid forskning på sårbare grupper som ivaretar disse hensynene samtidig.

\section{Referanser}

Cook, A.S. (2001). The dynamics of ethical decision making in bereavement research. I: M. Stroebe, R. Hansson, W. Stroebe \& H. Schut (red.), Handbook of bereavement research: Consequences, coping, and care (119-142). Washington, DC: American Psychological Association.

Cook, A.S. \& Bosley, G. (1995). The experience of participating in bereavementresearch: Stressful or therapeutic? Death Studies, 19 (2), 157-170.

Dyregrov, A., Dyregrov, K., Straume, M. \& Bugge, R.G. (2014c). Weekend family gatherings for bereaved after the terror killings in Norway in 2011. Scandinavian Psychologist, 1, e8. doi: 10.15714/ scandpsychol.1.e8. 
Dyregrov, K. (2003). The loss of child by suicide, SIDS, and accidents: Consequences, needs and provisions of help. Doctoral dissertation (dr.philos.). HEMIL, Faculty of Psychology. University of Bergen. ISBN 82-7669-099-8.

Dyregrov, K. (2004). Bereaved parents' experience of research participation. Social Science \& Medicine, 58 (2), 391-400.

Dyregrov, K. \& Dyregrov, A. (2000). Refugee families' experience of research participation. Journal of Traumatic Stress, 13 (3), 413-426.

Dyregrov, K., Dieserud, G., Hjelmeland, H., Straiton, M., Rasmussen, M.L., Knizek, B.L. \& Leenaars, A.A. (2011). Meaning making through psychological autopsy interviews. The value of participating in qualitative research for those bereaved by suicide. Death Studies 35, 685-710.

Dyregrov, K., Dieserud, G., Straiton, M., Rasmussen, M., Hjelmeland, H., Knizek, B. \& Leenaars, A. (2010-2011). Motivation for research participation among suicide bereaved. Omega - Journal of Death and Dying, 62 (2), 149-168.

Dyregrov, K., Dyregrov, A. \& Kristensen, P. (2014a). Traumatic bereavement and terror: The psychosocial impact on parents and siblings 1.5 years after the July 2011 terror-killings in Norway. Journal of Loss and Trauma, 1-21. doi:10.1080/15325024.2014.957603.

Dyregrov, K. \& Kristensen, P. (2015). Utøya 22. juli 2011 - senfølger for etterlatte foreldre [Utøya 22 July 2011 - psychosocial sequela for bereaved parents]. Scandinavian Psychologist, 2, e13. http://dx.doi. org/10.15714/scandpsychol.2.e13

Dyregrov, K. \& Kristensen, P. (2016). Selv om traumet er nasjonalt, er sorgen privat. http://psykologisk.no/2016/02/ selv-om-traumet-er-nasjonalt-er-sorgen-privat/

Dyregrov, K., Kristensen, P., \& Dyregrov, A. (2016). In what ways do bereaved parents after terror go on with their lives, and what seems to inhibit or promote adaptation during their grieving process? A qualitative study. Omega - Journal of Death and Dying. Published online before print June 8, 2016, doi: 10.1177/0030222816653851

Dyregrov, K., Kristensen, P. \& Johnsen, I. (2015). Etterlatte foreldre, partnere, søsken og venner etter Utøya-drapene 22.07.2011.

Oppsummering av forskningsprosjekt - $31 \frac{1}{4}$ år etter. Minirapport III. Senter for Krisepsykologi, Bergen. 
Dyregrov, K., Kristensen, P., Johnsen, I. \& Dyregrov, A. (2014b). Hvordan fungerte den psykososiale oppfølgingen for etterlatte etter 22. juliterroren? Scandinavian Psychologist, 1, e7. doi.org/10.15714/ scandpsychol.1.e7

Helsedirektoratet (2011). Laring for bedre beredskap. Helseinnsatsen etter terrorhendelsene 22. juli 2011. IS-1984. ISBN-nr. 978-82-8081-256-8.

Jaffe, A.E., DiLillo, D., Hoffman, L., Haikalis, M. \& Dykstra, R.E. (2015). Does it Hurt to Ask? A Meta-Analysis of Participant Reactions to Trauma Research. Clinical Psychology Review, doi: 10.1016/j. cpr.2015.05.004.

Johnsen, I., Laberg, J.C., Matthiesen, S.B., Dyregrov, A. \& Dyregrov, K. (2015). Psychosocial functioning after losing a close friend in an extreme terror incident. Scandinavian Psychologist. http://dx.doi. org/10.15714/scandpsychol.2.e5

Jorm, A.F., Kelly, C.M. \& Morgan, A.J. (2007). Participant distress in psychiatric research: a systematic review. Psychological Medicine, 37 (3), 917-926.

Keesee, N.J., Currier, J.M. \& Neimeyer, R.A. (2008). Predictors of grief following the death of one's child: The contribution of finding meaning. Journal of Clinical Psychology, 64 (10),1145-1163.

Kentish-Barnes, N., McAdam J.L., Kouki, S., Cohen-Solal, Z., Chaize, M., Galon, M. mfl. (2015). Research participation for bereaved family members: Experience and insights from a qualitative study. Critical Care Medicine, 43 (7), 1351-1555.

Kristensen, P., Weisæth, L. \& Heir, T. (2012). Bereavement and mental health after sudden and violent losses: A review. Psychiatry: Interpersonal and Biological Processes, 75 (1), 76-97.

Kvale, S. (1996). InterViews. An introduction to qualitative research interviewing. London: SAGE Publications.

Lakeman, R. \& Fitzgerald, M. (2009). The ethics of suicide research: The views of ethics committee members. Crisis, 30, 13-19.

Legerski, J.-P. \& Bunnell, S.L. (2010). The risks, benefits, and ethics of trauma-focused research participation. Ethics and Behavior, 20, 429-442.

Neria, Y., Gross, R., Litz, B., Maguen, S., Insel, B., Seirmarco, G., Rosenfeld, H., Suh, J. E., Kishon, R., Cook, J. \& Marshall, R.D. (2007). Prevalence and psychological correlates of complicated grief among 
bereaved adults 2.5-3.5 years after September 11th attacks. Journal of Traumatic Stress, 20 (3), 251-262.

Norris, F.H. (2007). Impact of mass shootings on survivors, families and communities. PTSD Research Quarterly, 18 (3), 1-8.

Omerov, P., Steineck, G., Dyregrov, K., Runeson, B. \& Nyberg, U. (2013). The ethics of doing nothing. Suicide-bereavement and research ethical and methodological considerations. Psychological Medicine, 1-12. doi: $10.1017 /$ S0033291713001670

Referat fra Komitémøte REK sør-øst D, 14. juni 2012 https:// helseforskning.etikkom.no/ikbViewer/Content/236518/ Komitem\%C3\%B8te.pdf

Smith, J.A., Flowers, P. \& Larkin, M. (2009). Interpretative Phenomenology Analysis. London: SAGE Publications. 


\section{KAPITTEL 5}

\section{Samarbeid, samtykkeerklæring og deling av data}

\section{Annika Melinder ${ }^{1}$ og Anne Marita Milde ${ }^{2}$}

In this chapter, we discuss how the wording of the informed consents may help to enable reuse of data in a more appropriate way for the individual participant, the involved researchers, and for society as a whole. We also discuss how collaboration between two research groups encompassed issues related to sharing and co-publication of data relating to health-related information from Utøya youth. Our conclusions are that the actors, who will be responsible for collecting data from a vulnerable population, must also be responsible for other parties' access to this data in a way that is transparent and adjusted. That way, the collaboration between researchers will be reinforced and stimulated and material can be better spent. REK might be such an unifying agent.

1 Professor, Psykologisk Institutt, Universitetet i Oslo

2 Førsteamanuensis, Institutt for biologisk og medisinsk psykologi, Universitetet i Bergen 


\section{Innledning}

Forskningssamarbeid har som hovedformål å skape et kunnskapsgrunnlag som er relevant for utviklingen av faget og ikke minst for samfunnets behov. De senere årene har det blitt en økende tendens at forskere etablerer samarbeid både lokalt, nasjonalt og internasjonalt gjennom opprettelse av tverrfaglige forskningsgrupper. Det er ofte et poeng at de enkelte forskerne har forskjellige perspektiver og faglige innfallsvinkler på temaer forskningsgruppen skal jobbe med. Samarbeidet kan være initiert av forskerne selv, men vi ser også at ulike utdanningsinstitusjoner og forskningsinstitutter krever at forskere danner grupper.

Etter 22. juli oppstod det diskusjoner knyttet til hvordan materialet fra de Utøya-berørte som ble samlet inn kort tid etter terrorangrepet, kunne deles med andre forskere. Våre forskningsprosjekter hadde i stor grad sammenfallende problemstillinger og forenlige metoder. Oslo-prosjektet «Nevrokognitive prosesser i etterkant av en traumatisk hendelse» ville undersøke hvordan en sterk og potensielt traumatisk hendelse påvirker hjerneaktivitet og klinisk, kognitiv og emosjonell fungering hos ellers antatt typisk utviklede individer, ved å bruke eksperimentelle design, kognitive tester og hjerneavbildningsteknikker. Bergen-prosjektet "Akutt stress på en hjerne i utvikling» hadde som mål å undersøke hvilke effekter en slik akutt traumatisk hendelse hadde for unge voksne mellom 16 og 25 år med hensyn til psykiske symptom, kognitiv fungering, døgnaktivitet, søvn samt fysiologisk stressrespons. Nevropsykiatrisk intervju, nevropsykologisk kartlegging, spørreskjema, aktigraf, spyttprøver (biokjemiske prøver) og hjerneavbildningsteknikker ble brukt.

I dette kapitlet fokuserer vi på hvordan forskningsetiske hensyn som deling og gjenbruk av data og krav om informert samtykke i økende grad utgjør sentrale temaer som bør håndteres i større satsinger. Problemstillingen vår er slik: Hvilke etiske utfordringer 
reiser forskningssamarbeid når det gjelder deling og gjenbruk av data, utforming av samtykke og felles publisering?

Når det er aktuelt å sørge for at samtykket også kan inkludere andre innfallsvinkler, for eksempel med koblinger av register, reises det spørsmål om hvordan informert samtykke fra deltagere i kliniske studier - ofte med sårbare grupper som hovedaktører - skal presenteres og sikres. Organiseringen og tilstrømningen av flere forskere og forskningsinstitusjoner i samarbeidets ånd får også betydning for hvordan forskerne selv forholder seg til data som blir samlet inn. Eierskap til data kan bli et diskusjonspunkt, og bør derfor avklares tydelig på et tidlig stadium av samarbeidet. Avtaler om deling av data samt om bruksrett til materialet, og eventuelt om fordeling av forfatterskap, fremstår dermed også som prekære faktorer å avklare før eventuelle konflikter oppstår.

\section{Deling og gjenbruk av data og organisering av samarbeid}

Det er et anerkjent etisk prinsipp i forskningssammenheng at datamateriale som hovedregel skal deles. Norges forskningsråd har eksplisitt gitt uttrykk for dette i sin policy vedrørende prosjektsøknader: «Forskningsrådets policy for åpen tilgang til offentlig finansierte forskningsdata skal bidra til at forskningsdata er tilgjengelige for relevante brukere, på like betingelser, til lavest mulig kostnad. Retningslinjene i policyen gjelder alle data i prosjekter som er finansiert av Forskningsrådet - med noen unntak» (Norges forskningsråd 2014). Unntakene dreier seg om forskning som kan true enkeltmenneskers eller nasjonens sikkerhet, eller som strider mot personvern. Data som har kommersiell verdi, kan også unntas.

Etter 22. juli-terroren ble det besluttet at Nasjonalt kunnskapssenter om vold og traumatisk stress (NKVTS) og Senter 
for Krisepsykologi (SfK), med støtte fra Helsedirektoratet, skulle få direkte tilgang til kartlegging og oppfølgning av berørte som var på Utøya, og til de etterlatte. I bevilgningen fra Helsedirektoratet til etableringen av forskningsprogrammet ble det fremhevet at «NKVTS vil videre etablere en infrastruktur knyttet til datamaterialet som samles inn, slik at datasettet kan gjøres tilgjengelig for andre forskningsmiljøer» (tilskuddsbrev fra Helsedirektoratet til NKVTS, prosjekt 030303, datert 16.11.2011, vår kursivering). Utover at Helsedirektoratet forutsatte «tett dialog, faste møter, milepælsmål mellom NKVTS og oppdragsdepartementene angående fremdrift ...», ble det ikke eksplisitt formidlet når datamaterialet skulle bli tilgjengelig for andre forskere. Fortolkningen av dette ble derfor en diskusjon mellom NKVTS og ulike parter.

Senere ble det nedsatt en koordineringsfunksjon av forskningen knyttet til 22. juli-terroren tilknyttet De nasjonale forskningsetiske komiteene (FEK). Hensikten var å bidra til at ulike forskere kunne komme sammen for å dele og tilrettelegge datamateriale. Hovedformålet var å forhindre overbelastning med mange og separate henvendelser om forskningsdeltagelse for allerede sterkt utsatte og sårbare grupper, $\mathrm{i}$ tråd med de etiske forutsetningene som fulgte av tildelingen. Koordineringsgruppen fikk tilsendt alle søknader som omhandlet 22. juli-forskningen, og den ble dermed raskt oppmerksom på andre nasjonale aktører som ønsket å samle inn data knyttet til terrorangrepet. Koordineringsgruppen sørget så for å koble sammen forskningsgrupper med lignende problemstillinger med oppfordring til direkte samarbeid.

\section{Informert samtykke og innsamling av data}

All forskning som inkluderer innsamling av personopplysninger, skal basere seg på at den enkelte deltager har gitt «frivillig og 
informert samtykke». Begrepet er sentralt i Helsinkideklarasjonen fra 1964 med revisjoner (den siste i 2013), som gir veiledende etikk og regler for forskning knyttet til mennesker. Formålet med deklarasjonen er å beskytte mulige deltagere i forskningsprosjekter mot farer som følger av (biomedisinsk) forskning (Molven 2013). Formelt gis samtykke vanligvis ved at forsøkspersonen gir sin underskrift, noe som også indikerer at informasjon om studiens formål, bakgrunn, eventuelle oppdragsgivere og forskningens relasjon til andre grupper er mottatt (Winther 2009). Den som gir sitt samtykke, skal ikke være under noen form for press eller avhengighet til den som gjennomfører forskningen. Generelt er det derfor viktig at forskeren vektlegger å forklare forskningens relasjon til det omkringliggende apparatet, siden dette ikke alltid er innlysende for ikke-forskere. Dette kan innebære å forklare forskningens relasjon til oppdragsgiver, etiske komiteer og forskningsinstitusjonens egen involvering i utforming av tjenester som berører deltageren, og/ eller i behandling eller oppfølgning av deltageren.

Vi tar utgangspunkt $\mathrm{i}$ at Regionale komiteer for medisinsk og helsefaglig forskningsetikk (REK) kun skal godkjenne medisinske og helsefaglige prosjekter som faller inn under helseforskningsloven. Det innebærer blant annet at søknadene skal vise til rimelige kostnad-nytte-analyser, det vil si at nytten med prosjektet overveier den eventuelle ulempen for den enkelte deltager som studien medfører. Utgangspunktet er at sårbare grupper må beskyttes fra pågang fra forskere og/eller fra forespørsler om deltagelse i prosjekter som ikke er designet på en forskningsetisk eller metodisk god måte.

I studier som godkjennes av REK - og som har potensial til å kunne utvikles utover de(n) aktuelle problemstillingen(e) - kan det likevel være aktuelt å innarbeide rutiner for hvordan gjenbruk av innsamlet materiale skal foregå. Et eksempel er hvordan data fra Den norske mor og barn-undersøkelsen (MoBa) 
ved Folkehelseinstituttet er ivaretatt. Samtykkeerklæringen som deltagere til MoBa signerer, er formulert slik at gjenbruk av data er mulig. Det forutsetter selvfølgelig at deltagerne samtykker til gjenbruk i den «nye» studien. Men kobling forekommer også omvendt der hvor forskeren ser at allerede innsamlet materiale kan gjøres enda mer relevant dersom kobling til et større registermateriale blir gjort.

Når det gjelder Utøya-materialet, ble slike samtykkeerklæringer om gjenbruk av materialet ikke formulert. Kort tid etter at NKVTS og SFK fikk ansvar for og direkte tilgang til oppfølgingen av berørte og etterlatte, oppstod det derfor et vakuum for andre forskere som ønsket å undersøke andre typer problemstillinger på det samme feltet.

Her møter vi på to relaterte forskningsetiske dilemmaer. Det første er hvordan forskningsdeltakernes interesser best ivaretas. På den ene siden kan det hevdes at en avgrenset samtykkeerklæring der deltagerne avgrenser sitt samtykke til én studie, er et gode. Deltageren - og forskningsaktørene som er involvert - har på den måten bedre kontroll over hvordan opplysninger brukes og oppbevares. På den annen siden kan en løsning med begrenset samtykkeerklæring bidra til at sårbare unge, i dette tilfellet Utøya-ungdom, ble kontaktet av flere ulike forskere og forskningsgrupper. Dette kunne fremstå som belastende og i hvert fall ukoordinert og kanskje også uprofesjonelt fra deltagernes perspektiv. Forsiktighetsnivået som ble utvist fra både NKVTS og REK, var forståelig nok høyt, men konsekvensen var at det hindret deling av data på et tidlig tidspunkt.

Det andre dilemmaet gjelder forskernes og forskningsinstitusjonens interesser. På den ene siden krever posisjonen som begunstiget forskningsinstitusjon med plikt til å dele forskningsdata et høyt aktsomhetsnivå i balansegangen mellom egeninteresser og allmenninteresser. I dette ligger at institusjonene skal påse at 
samtykkeerklæringene ikke blir uthulet eller tøybare. Samtidig har de samme institusjonene et legitimt behov for å beskytte sitt eget materiale, noe som setter dem i en dobbeltposisjon, der motvilje mot å dele data enten kan tolkes som et ønske om å beskytte informantene eller som et forsøk på å bruke hensynet til informantene som argument for å beskytte egne interesser.

\section{Samarbeid for å bedre deltagerandelen}

Mangelen på formuleringer i samtykkeerklæringene, som kunne åpne for gjenbruk av materialet og bruk av deltagerlister for rekruttering, vanskeliggjorde gjennomføring med tilstrekkelig deltagelse for kvantitative design i våre prosjekter. Først da koordineringsfunksjonen for 22. juli-forskning kom i gang og sentrale aktører ble oppfordret til å samarbeide, ble henholdsvis Universitetet $\mathrm{i}$ Bergen (UiB) med prosjektet «Akutt stress på en hjerne i utvikling» og Universitetet i Oslo (UiO) med prosjektet «Nevrokognitive prosesser i etterkant av en traumatisk hendelse» gjort oppmerksom på overlappende prosjektsøknader til REK.

Dette ble begynnelsen på et samarbeid. I løpet av et par uker hadde de to prosjektgruppene diskutert seg frem til en praktisk måte å dele deltagere på (geografisk), og i tiden som fulgte, fant vi også frem til prosedyrer for deling av data, analyse og skriving av materialet. På grunn av allerede innsendte og godkjente REKsøknader var det begrenset hvor mye Bergen og Oslo kunne tilpasse design med tanke på felles variabler. Det ble tatt avgjørelser om å sende endringsmeldinger for å kunne inkludere søvnkartlegging og biokjemiske prøver i Oslo, samt endringer av enkelte oppgaver som deltagerne skulle utføre ved de funksjonelle MR-målingene (fMRI) i Bergen. De to prosjektene hadde noe forskjellige utfordringer.

Oslo-prosjektet ble etablert kort tid etter terrorangrepet, og søknad til REK om godkjenning ble første gang sendt 13. desember 2011. 
REK mente at rekruttering gjennom AUFs adresselister og deres bistandsadvokater var tilrådelig. Dette gav imidlertid lite respons siden AUF sentralt ikke ønsket å være involvert i slikt formidlingsarbeid fordi de allerede deltok i forskning (ved NKVTS og SFK). AUF oppfordret oss derfor til å kontakte Støttegruppen etter 22. juli for rekruttering, da denne gruppens mandat blant annet var å følge opp henvendelser rettet mot overlevende og etterlatte. Selv om støttegruppen var positiv til forskningen, var medlemsmassen ikke primært bestående av de ungdommer vi søkte etter. Vi henvendte oss deretter til de tre koordinerende bistandsadvokatene. Av disse tre koordinerende bistandsadvokatene var det kun én som gav tilbakemelding, men vi fikk heller ikke deltagere via disse aktørene. Rekrutteringen av de ungdommene som til slutt ble inkludert i studien, ble derfor innhentet ved at private kontakter spredte informasjonen videre. I tillegg møtte forskerne opp ved noen møter i regi av lokallag av AUF som vi ble invitert til. Psykologisk institutt ved $\mathrm{UiO}$ innvilget midler til en ph.d.-stilling og drift av prosjektet som en gave til 22. juliforskningen ${ }^{3}$, og prosjektet ble organisert med prosjektleder, interne samarbeidspartnere og doktoranden.

Bergen-prosjektet kom raskt i gang med utforming av prosjektbeskrivelse og postdocsøknad. UiB hadde via forskers tilknytning til RVTS tilgang til kontaktinformasjon til ungdom som hadde bidratt i NKVTSs studie, fra region Vest. Selv om dette innebar en klart definert begrensning i antall deltagere, muliggjorde det direktekontakt med potensielle deltagere. Gjennom Bergen fMRI-gruppe ble det opprettet et internt samarbeid ved UiB med RVTS Vest som ekstern samarbeidspartner. Prosjektsøknad ble sendt Helse Vest, og det ble innvilget støtte for postdoc samt forskningsmidler for ett år med mulighet til forlenget støtte med inntil ett år til. Bergens utfordring var finansiering av prosjektet. 
Leder for Bergen fMRI-gruppen, Institutt for biologisk og medisinsk psykologi ved UiB, Nasjonal kompetansetjeneste for søvnsykdommer (SOVno), og etter hvert vår samarbeidspartner for dette prosjektet ved UiO bidro med nødvendige midler som kunne dekke kostnader i forbindelse med hjerneavbildning, analyser av biokjemiske prøver (saliva kortisol) og søvnkartlegging.

\section{Spørsmål knyttet til forfatterskap og kreditering}

I takt med at publiseringskravene har økt og førsteforfatterskap sammen med sisteforfatterskap er blitt det foretrukne, er forskernes relasjon til hverandre blitt en mulig stressfaktor som må løses i ethvert samarbeid. Således dreier forskningsetikk seg ikke bare om forholdet mellom forskeren og deltageren i forskningsprosjektet, men om relasjonen mellom forskerne. Viktigheten av avtaler om hvem som skal publisere hva, hvordan medforfatterskap skal beregnes, og hvordan deltagelse på ulike aktivitetsnivåer skal krediteres, er sentrale temaer i forskningsetikken og reflekteres i Vancouver-reglene (2015). Vi har dermed delt mesteparten av dataene etter innsamling og analyse/koding. Der hvor det ikke er sammenligningsbare delmålinger (tester), har vi splittet dataanalyse og skriving mellom instituttene. En klar svakhet har da vært knyttet til reduksjon i antall deltakere. Dette har resultert i problemer med å få artikler akseptert i internasjonale tidsskrift med fagfellevurdering.

En styrke i våre prosjekter har først og fremst vært kommunikasjon, og en holdning til at materialet skal brukes til fellesskapets beste, og med det til det beste for våre deltagere, som har investert mye av seg selv i relativt krevende oppgaver og undersøkelser.

Vi rangerer forfattere slik at både Bergens og Oslos involvering skal fremgå, og vi fordeler første- og sisteforfatter rettferdig 
mellom gruppene så langt det er mulig ut fra Vancouver-reglene (2015). En annen utfordring har vært å dimensjonere materialet slik at det ikke blir dobbeltpublisering av data. Dette er selvfølgelig et risikoaspekt også ved interne større prosjekter, men blir ekstra presset i samarbeidsprosjekter mellom forskningsmiljøer siden de på hver sin side kan ha ytterligere samarbeidspartnere som vil koble seg på med andre vinklinger på det samme materialet. Manuskripter som omhandler MR-data, har gjentatte ganger blitt refusert med blant andre begrunnelser om, som nevnt over, for få deltagere. Dette har gjort at publisering har blitt mer forsinket enn forventet.

Begge miljøene har hatt et spesifikt ansvar for henholdsvis ph.d.-er og postdoc. Det har dermed vært diskusjoner om forfatterskap hvor intensjonen har vært å kunne ivareta deres behov for førsteforfatterskap, men også å kunne få til en rimelig fordeling av annen- og sisteforfatterskap. Et prinsipp har her vært å prioritere Oslo som annen og/eller siste forfatter dersom Bergen er første forfatter, og omvendt. I forlengelsen av analysearbeid har det på begge sider vært viktig å inkludere internasjonale forskere med spisskompetanse på ulike felt. Vår vurdering har vært at disse stort sett kan ha mellomforfatterposisjoner som synliggjør deres metodiske bidrag mer enn idé, utarbeidelse av manuskript og ansvar. Det har ført til inklusjon av flere forfattere og et styrket strategisk forskningssamarbeid mellom anerkjente institusjoner. Men det medfører også en utfordring $\mathrm{i} a ̊$ håndtere ulike syn på hvordan data skal analyseres og presenteres, og en slik prosess har bidratt til å forsinke ferdigstillelse av artikler.

Det er full åpenhet om skriveprosessene, og alle forfattere kan kommentere på de ulike versjoner av arbeidene. Førsteforfatter har, selvsagt, tatt størst ansvar for skriveprosessen, inklusive analyser av data og revisjoner av manuskript. Naturlig nok vil noen ta et større ansvar for tekniske sider ved for eksempel fMRI eller 
søvnregistreringer, mens andre tar et mer overordnet ansvar for statistiske beregninger, formuleringer og/eller tilpasser teksten til en gjeldende stil, for eksempel i tråd med American Psychological Association (APA). Stort sett har det falt seg naturlig at annen- og sisteforfatter har tatt et ekstra ansvar etter førsteforfatter.

\section{Oppsummering og forslag til vei videre}

Oppsummert er våre erfaringer med koordineringsgruppen gode, og vi kan støtte opp under opprettelse av lignende organer i andre saker hvor det er sentralt at forskere samarbeider og deler materiale. En gjennomgang og refleksjon av prosedyrer for tillatelser, prioriteringer og involverte aktører som gjøres allment tilgjengelig, kan forebygge at forskere må gjøre krumspring for å sikre seg tilgang til kilder og datamateriale. Hvordan samtykkeerklæringer formuleres, er viktig for hvordan materiale senere kan deles som via en databank. Aktører som får ansvar for å samle inn data fra en populasjon, bør ansvarliggjøres, slik at data som hovedregel kan deles med andre aktører på en transparent og tilpasset måte. Arbeidet med utformingen av samtykkeerklæringene i de prosjekter som direktorat, departement og Forskningsrådet støtter, fremstår som et moment forskere og etiske komiteer i større grad og i fellesskap bør prioritere i fremtiden. REK kan være en viktig instans for å sikre at slike vurderinger blir gjort. En klar fordel ved at REK involverer seg i dette, vil være å unngå proteksjonistiske handlinger fra søkerens side som kunne være uheldige sett fra et samfunnsmessig nytteperspektiv. Samtidig påhviler det den enkelte forsker et ansvar.

En forutsigbar forskningsprosess kan styrke kvalitet på forskning og bidrar til at etiske prinsipper og retningslinjer bedre kan ivaretas, samt ikke minst at forskningssamarbeid innenfor og på tvers av land får gunstige vekstvilkår. 


\section{Referanser}

Lov om medisinsk og helsefaglig forskning (helseforskningsloven) (2008-06-20). Helse- og omsorgsdepartementet.

Molven, O. (2013, 4. juni). Helsinkideklarasjonen. I Store medisinske leksikon. Hentet 28. desember 2015 fra https://sml.snl.no/ Helsinkideklarasjonen.

Nylenna, M., Fagerbakk, F. \& Kierulf, P. (2014). Authorship: attitudes and practice among Norwegian researchers. BMC Medical Ethics. 15:53. doi: 10.1186/1472-6939-15-53

Norges forskningsråd (2014, 15. oktober). Åpen tilgang til forskningsdata. http://www.forskningsradet.no/no/Artikkel/Apen_ tilgang_til_forskningsdata/1254001013535 (lastet ned 10.03.16)

Vancouverkonvensjonen (revidert i 2015). Tilgjengelig på http://www. icmje.org/icmje-recommendations.pdf

Bahus, M.K. (2016, 4. mai). Informert samtykke. I Store medisinske leksikon. https://snl.no/informert_samtykke (lastet ned 01.08.16)

World Medical Association (WMA) (revised 2013). Declaration of Helsinki - Ethical Principles for Medical Research Involving Human Subjects. Tilgjengelig på http://www.wma.net/ en/30publicatiobs/10policies/b3/index.html 


\section{KAPITTEL 6}

\section{Følgeforskning og minneprosesser på Utøya 2013-2014}

\section{Tor Einar Fagerland ${ }^{1}$}

In August 2015 the Labour Youth League was back at Utøya for their annual summer camp. It took four years to return to the island that since 1950 has been a crucial part of the identity of the organization. In order to do so, the Labour Youths had to address the island's double-memory of youthful joy on one side, and the terror of July 22 when 69 camp participants were brutally murdered on the other. Finding a way to allow for both memory and for new life was a difficult task in which there was no prescribed template. In 2013 the Labour Youth League invited a group from the ongoing research project "July 22 and the negotiation of memory" at NTNU to become a part of the process as advisors. Historians and museum-experts like James Young, Ed Linenthal, Alice Greenwald and I were by this turned into guides and hands-on participants. This affected both our research project and the way the Labour Youth chose to move forward at Utøya.

1 Leder og førsteamanuensis ved Institutt for historiske studier, Norges teknisknaturvitenskapelige universitet, NTNU 
The text is an analysis of the process at Utøya 2011-2015. A special emphasis will be on the methodological and ethical issues.

\section{Innledning}

I august 2015 ble det for første gang etter terroren 22. juli 2011 arrangert sommerleir på Utøya. Det tok fire år for Arbeidernes Ungdomsfylking (AUF) å komme tilbake til øya som siden 1950 har vært en essensiell del av organisasjonens identitet. Disse fire årene uten Utøya-leir var for mange AUF-ere lang tid. For mange etterlatte familier, derimot, var fire år kort tid. Mange ulike hensyn måtte derfor ivaretas på veien tilbake etter massakren som i 2011 krevde 69 leirdeltakeres liv.

I mai 2013 ble jeg som leder av det NTNU-initierte forskningsprosjektet «July 22 and the negotiation of memory» invitert av AUF til å bistå i deres arbeid med å komme tilbake til Utøya. Med i rådgiverteamet ble også tre av prosjektets internasjonale partnere, James E. Young, Ed Linenthal og Alice Greenwald. En av utfordringene knyttet til Utøya var å finne meningsfulle måter å balansere på behovet for å minnes det som skjedde 22. juli, samtidig som en la til rette for nytt liv og ny aktivitet. Det var i denne delen av arbeidet vårt forskningsprosjekt ble bedt om å bistå, først som samtalepartnere og siden også som «hands on» rådgivere. Dette endret vår rolle som forskere, og det endret også AUFs syn på hvordan prosessen på Utøya skulle tas videre. I et samfunnsperspektiv er resultatet og det at AUF faktisk lyktes i å komme tilbake til Utøya, klart viktigst. I denne teksten legges det mest vekt på prosessen som ledet fram til gjenåpningen av Utøya, og på de etiske og metodiske utfordringene vi som forskere og rådgivere møtte i samarbeidet vårt med AUF, overlevere og berørte.

Gjennom å samarbeide med AUF gikk vi fra mai 2013 gradvis over fra å forske på prosessen på Utøya fra utsiden til å forske på 
den fra innsiden. Vi gikk også fra en passiv observerende rolle og over i en aktiv deltakende rolle. Denne teksten er en egenrefleksjon rundt prosessen på Utøya og forskergruppens deltakelse i denne i tidsrommet 2013-2014. I teksten vil jeg gjøre rede for prosessen fra terrorangrepene i $2011 \mathrm{og}$ fram til øya ble gjenåpnet sommeren 2015. Parallelt med dette løfter jeg fram og drøfter noen av de utfordringene og dilemmaene vi møtte da forskergruppen vår beveget oss fra observatører, via samtalepartnere til «hands on» deltakere.

\section{July 22 and the negotiation of memory}

Representasjoner og fortolkninger av historie og fortid i det offentlige rom sier mye om et samfunns verdier, om et samfunns selvbilde og om hvordan et samfunn ønsker å fremstille seg for andre. Hvilke historier og minner som blir løftet fram, og tilsvarende hvilke historier og minner som blir glemt, fortrengt eller marginalisert, faller inn under det en i historiefaget kaller «et samfunns minnepolitikk». I totalitære samfunn er minnepolitikken som regel toppstyrt, mens det i åpne og demokratiske samfunn i mye større grad foregår debatter om hva som skal minnes, hvor dette skal skje, hvem som skal minnes, og hvorfor spesifikke hendelser skal minnes og andre ikke (Fagerland 2013). Forskningslitteraturen på feltet er omfattende og har i senere år fokusert spesielt på minnearbeid og bearbeiding etter terror og angrep på åpne samfunn og deres demokratibaserte kjerneverdier.

I norsk etterkrigshistorie har imidlertid politisk terror vært noe som skjedde andre steder og ikke i det fredelige Norge. Angrepet på regjeringskvartalet og massakren på Utøya 22. juli 2011 kom derfor som et sjokk på det norske samfunn, og utløste umiddelbart et behov for å komme sammen, for å søke trøst, og for å finne mening i det meningsløse. I sentrale deler av Oslo, på fastlandssiden ved Utøya og mange andre steder ble det i dagene 
etter hendelsen laget spontane samlingssteder hvor folk kom sammen, holdt rundt hverandre, snakket sammen, la ned blomster og hilsener. Etablering av «spontane minnesteder», som det heter i faglitteraturen, er de seneste tiårene blitt et utbredt fenomen etter traumatiske hendelser og fant sted i stor skala også etter terrorangrepet i Oklahoma City i 1995, på Manhattan etter 9/11 og i Madrid etter Al Qaida-angrepet i 2004 (Margry and SánchezCarretero 2011; Doss 2008).

Ved årsskiftet 2011/2012, altså knappe halvåret etter terrorangrepene, ble det igangsatt en regjeringsinitiert prosess knyttet til etablering av to nasjonale minnesteder for å minnes 22. juli, hvorav ett skulle etableres i Oslo og ett på landsiden ved Utøya i Hole kommune. I tillegg ble det lansert et omfattende privatinitiert prosjekt fra en anonym giver som førte til etablering av identiske 22. juli-monumenter i 52 kommuner over hele landet (Magnusson 2015). Det ble også igangsatt en rekke mindre 22. juli-relaterte prosjekter av ulik karakter, og ikke minst hadde AUF sin egen prosess gående på Utøya. Ved Program for kulturminneforvaltning, Institutt for historiske studier, NTNU, har vi lenge arbeidet med tematikker knyttet til kollektivt minne og håndtering av vanskelig historie (Fagerland \& Nilssen 2011; Fagerland 2014a; Fagerland 2014b; Fagerland \& Hjorth 2016). Med basis i denne kompetansen og med støtte fra NTNU opprettet vi i 2012 en forskergruppe med undertegnede som prosjektleder, og i 2013 ble prosjektet også tilført to ph.d.-stipendiater (Line Gjermshusengen og Ingeborg Hjorth).

Minneprosesser etter traumatiske hendelser dreier seg ikke bare om å forstå og å minnes spesifikke hendelser, men like mye om relasjonen mellom hendelsen og samfunnets kjerneverdier (Suleiman 2008). Tittelen «July 22 and the negotiation of memory» understreker nettopp at våre sosiale og kulturelle minner ikke er noe som er, men noe som skapes og gjenskapes i dynamiske og 
komplekse forhandlinger. ${ }^{2}$ Mange land har flere og mer dyrekjøpte erfaringer med terror enn Norge. En sentral del av vår prosjektdesign var derfor fra begynnelsen av å involvere forskere med erfaring fra traumatiske minneprosesser andre steder. De viktigste av disse er James E. Young, som hadde en sentral rolle i minneprosessene etter 9/11 i New York, Ed Linenthal, den fremste eksperten på det høyreekstreme terrorangrepet i Oklahoma City i 1995, og Alice Greenwald, direktør ved 9/11 Memorial Museum.

I historiefaget er analytisk og tidsmessig distanse til analyseobjektene til vanlig et sentralt og styrende prinsipp. Nå det gjaldt dokumentasjon av den samfunnsmessige bearbeidingen av 22. juli, derimot, veide vi viktigheten av å komme raskt i gang som mer avgjørende. Dette fordi vi ønsket å sikre oss tilgang til kildemateriale fra skjøre (og ofte lukkede) prosesser, som vi så for oss kom til å ha komplekse og uforutsigbare forløp. Internasjonalt er følgeforskning av pågående minneprosesser blitt stadig mer utbredt og da gjerne i en form hvor tekstanalyse, intervjuer, befaring og deltakende observasjon kombineres. Et eksempel på dette er Ed Linenthals prisbelønte arbeid om minneprosessene etter terrorbomben i Oklahoma City i 1995 (Linenthal 2001a; 2001b). Mens vårt arbeid knyttet til de privatinitierte minnestedene er ren følgeforskning basert på innsamling og analyse av skriftlige og muntlige kilder samt fysisk befaring og fotodokumentasjon, har arbeidet med andre deler av minneprosessene brakt oss tettere på både aktører og prosesser. Under arbeidet med å dokumentere de nasjonale minnestedsprosessene har for eksempel medlemmer av vår forskergruppen vår ved flere anledninger gitt faglig bistand, blant annet gjennom minnefaglig kontekstualisering av pågående prosesser. Tilsvarende «oppdrag» har vi også hatt inn mot etableringen av en 22. juli-park i Trondheim sentrum initiert

2 For mer informasjon om forskningsprosjektet, se https://www.ntnu.no/july22memory 
av Trondheim kommune. Det var imidlertid etter å ha blitt invitert inn i prosessen på Utøya at arbeidet vårt tok nye og mer intervenerende former. Innad i forskergruppen vår var imidlertid heller ikke denne typen arbeid ukjent. James E. Young brakte for eksempel inn i forskergruppen omfattende «hands on» erfaring fra Berlin og New York i hvordan forsker- og deltakerrollen kan balanseres og deretter omgjøres til forskning med faglig overføringsverdi (Young 2000; 2006).

Det følgende er en analyse av første del av prosessen på Utøya (2011-2012) sett fra utsiden, etterfulgt av en analyse av andre del (2013-2014) sett fra innsiden. Avslutningsvis følger en vurdering av prosessen, vårt forskningsprosjekts rolle, og etiske og metodiske refleksjoner knyttet til dette.

\section{Minnemarkering og lansering av «Nye Utøya»}

I en direktesendt pressekonferanse dagen etter terrorangrepene slo AUF-leder Eskil Pedersen fast at "AUF skal tilbake til Utøya» (Pedersen 2011). I løpet av dette første døgnet var Utøyas form og bygninger blitt kjent for hele Norge. Den hjerteformede øya og det hvite hovedhuset med Utøya-skiltet gikk verden over, og uttalelsen og standhaftigheten som lå bak, fant mening og resonans hos mange overlevende og berørte. Dette gjaldt også i brede lag av den norske offentlighet, hvorfra penger begynte å strømme inn til det nyopprettede Utøya-fondet, et fond som etter kort tid kom opp i 40 millioner kroner fra et utall små og noen store givere. Hele det norske samfunnet var på denne tiden sterkt preget av terrorangrepet. Lokalsamfunn, fra Kristiansand i sør til Svalbard i nord, sto stille under en endeløs rekke begravelser, og nasjonale minneseremonier fra Oslo domkirke (24. juli) og fra Oslo Spektrum (22. august) ble direktesendt på de 
store TV-kanalene. Rosetog ble arrangert landet over 25. juli, og rettssak, dom og 22. juli-kommisjonens rapport preget nyhetsbildet ut sommeren 2012 .

Det nasjonale samholdet i den første intense fasen er noe mange husker, og også et trekk i bearbeidingen som er fremhevet i etterkant (Fagerland 2016; Kverndokk 2012). Gradvis ble konsensusen utfordret av spørsmål rundt samfunnets beredskap, rundt gjerningsmannen tilregnelighet og rundt fordeling av ansvar. Spissformulert kan man si at 22. juli gikk fra å være en dag da vi som fellesskap «sto sammen mot ondskap», til en dag da «mye som kunne gå galt, på tragisk vis også gikk galt». Det ble diskutert rundt gjerningsmannens tilregnelighet, om hvem som skulle stå til ansvar for manglende koordinering av samfunnsberedskap. Også forslagene til lokalisering av nasjonale minnesteder møtte i april 2012 sterk kritikk (Styringsgruppen for minnesmerker/minnemonumenter 2012; Valebrokk 2012). Samtidig begynte diskusjon og usikkerhet rundt videre bruk av Utøya å gjøre seg mer gjeldende. Hele Norge begynte å mene noe om den lille øya i Tyrifjorden og veien videre. Skulle AUF virkelig tilbake dit? Og i så fall: Når kunne og burde dette skje, og på hvilken måte? Hva mentes med «Nye Utøya»? Hva kunne øya brukes til, hva kunne den ikke brukes til? Hvilke bygg skulle rives? Hvilke skulle bestå?

For AUF og de etterlatte familiene var det første året fylt av begravelser, rettssak, sinne og sorg. Imens gikk månedene på Utøya, det fantes ingen klar retning, fremdriften var liten og kommunikasjon innad og utad ofte mangelfull. Ikke rart kanskje, for hvor finner man fasiten på å gå videre etter en massakre av 69 mennesker på en øy eid av en politisk ungdomsorganisasjon? Vanskelig skulle imidlertid gå til vondt da AUFs planer for ettårsmarkeringen på Utøya 22. juli 2012 ble kjent. Her kom det fram at AUF mellom kl. 12 og 17 planla et arrangement med en 
klar politisk profil med deltakelse, blant annet, av de daværende statsministrene Jens Stoltenberg og Helle Thorning-Schmidt (Danmark). Etterlatte og pårørende skulle etter denne planen kun ha adgang til øya forut for dette arrangementet. Etter store medieoppslag og påfølgende forhandlinger ble planene justert slik at etterlatte fikk adgang til Utøya også etter kl. 17 (Brev fra etterlatte til AUF 2012; Brev fra AUF til etterlatte 2012).

Skuffelsen flere berørte følte over det de opplevde som manglende følsomhet fra AUFs side, gikk hos noen over i sinne da planene for «Nye Utøya» ble lansert 7. september 2012 (Dagbladet 2012). Som en del av AUFs visjon for et nytt, større og mere funksjonelt leirsted skulle flere bygninger, inkludert pumpehuset og kafébygget, der henholdsvis 14 og 13 ble drept, rives allerede samme høst (NRK 2012). De nye planene tydeliggjorde avgrunnen mellom utålmodige AUF-ere og mange av de pårørende. Flere av de berørte ønsket ikke sommerleir på Utøya, og i hvert fall ikke ennå. Kort tid etter ba en gruppe etterlatte Riksantikvaren om å frede alle bygningene på øya, blant annet med den begrunnelse at Utøya nå var blitt «vårt Auschwitz» (TV 2 2012). Riksantikvaren fant ikke at Utøya og bygningsmassen falt inn under gjeldende fredningsbestemmelser, men henvendelsen til Riksantikvaren og svaret derfra fikk bred dekning i mediene (Riksantikvaren 2012).

Presset på de unge AUF-erne var høsten 2012 stort: medier, pårørende, fem millioner nordmenn. Alle mente noe, og ingen omforent løsning var i sikte. Selve symbolet på den fastlåste situasjonen var kafébygget. For noen av de 13 familiene som mistet sine kjære her, var bygget allerede et skjørt og «hellig» minnested. For andre, mange AUF-ere inkludert, var bygget et stort og ruvende «dødens hus» som sto i veien for nytt liv og ny aktivitet. AUF skjønte at de måtte gjøre noe, men visste ikke hva. De skulle ta Utøya tilbake, men fattet ikke hvordan. 


\section{Ny start og nytt samarbeidsprosjekt}

Et midlertidig kompromiss ble inngått da AUF senere samme høst ble enige med Nasjonal støttegruppe etter 22. juli-hendelsene om å utsette alt av rivningsplaner til 2014 (Aftenposten 2012). På samme tid reiste Jørgen Watne Frydnes, daglig leder på Utøya, landet rundt for å møte de berørte familiene og høre deres tanker om Utøya og veien videre. Dialogen mellom AUF og etterlatte, som tidligere hadde vært mangelfull, ble dermed i løpet av høst 2012 og vår 2013 mer omfattende og mer systematisert.

Vårt arbeid med 22. juli hadde på denne tiden ført til kontakt og dialog med sentrale aktører og beslutningstakere i de ulike prosessene. I april 2013 holdt jeg en forelesning for kunstutvalget for de nasjonale minnestedene etter 22. juli, hvor min oppgave var å sette den norske prosessen inn i en internasjonal sammenheng. ${ }^{3}$ En av tilhørerne var AUFs representant i kunstutvalget, Mari Aaby West, og dette ble innledningen på en dialogbasert og stadig tettere kontakt mellom vårt prosjekt og AUF. I den første fasen foregikk det primært som samtaler mellom Aaby West og Watne Frydnes fra AUF og undertegnede som leder for forskningsprosjektet. Gradvis ble dialogen utvidet til å inkludere prosjektets internasjonale ekspertise, og i løpet av høsten 2013 var både Ed Linenthal og James E. Young på Utøya for å observere hvilke utfordringer AUF, de berørte og det norske samfunnet sto overfor. Tross sin lange erfaring med minneprosesser gjorde Utøya et sterkt inntrykk på dem begge. Spesielt gjaldt dette kontrasten mellom øyas naturskjønnhet og stolte historie på den ene siden og de ufattelige grusomhetene 22. juli 2011 på den andre. Stående ved pumpehuset hvor 14 ungdommer ble drept, ønsket Linenthal å vite hvilke

3 Forelesningen inngår i bearbeidet form i Kunstplanen fra KORO som ble lagt til grunn for den internasjonale minnestedskonkurransen for 22. juli-minnesteder. http://minnesteder.no/wp-content/uploads/Kunstplan1.pdf 
tradisjoner vi i Norge har for å håndtere denne typen landskap og hendelser. Svaret jeg da ga, var at med unntak av okkupasjonsårene 1940-45 var Norge forskånet fra vold i masseskala, og at hjemlig terror var vårt samfunn så godt som ukjent med. Det fantes derfor minimalt med erfaring og lite av nasjonale praksiser å bygge på. Samtaler som dette førte også til at AUF-ere så på prosessen de sto i, med nye øyne. At prosessen de sto i, var krevende, visste de fra før, men nå ble det også satt ord på hvorfor det var slik.

Dialogen vi hadde med AUF under disse befaringene, ble oppfattet som meningsgivende, og i februar 2014 ble samarbeidet, etter ønske fra AUF, formalisert. Vi opprettet da en ressursgruppe som ikke bare skulle være samtalepartner, men også gi konkrete råd spesielt knyttet til kafébygget. I tillegg til Young, Linenthal og undertegnede ble også direktør ved 9/11 Memorial Museum i New York Alice Greenwald, AUF-veteran og Utøya-historiker Jo Stein Moen og arkitekt Erlend Blakstad Haffner innlemmet i ressursgruppen. Haffner var også formmessig ansvarlig for planene som ble presentert i september 2012, og representerte dermed forbindelsen mellom prosessen det første året og de endringer og bearbeidinger som lå foran, i det videre arbeidet.

Etter kontroversene rundt «Nye Utøya» i 2012 ble AUFs planer om sommerleir på Utøya skrinlagt. Avtalen med nasjonal støttegruppe innebar også at det ikke skulle være sommerleir på øya i 2014. Mens AUF avsto fra å arrangere sommerleir i 2012, ble det likevel avholdt sommerleir både i 2013 og 2014, men da på Gulsrud på landsiden av Tyrifjorden. For AUF hadde sommerleirene på Utøya over flere tiår spilt en sentral rolle for organisasjonens identitet. Her ble nybakte ferskinger omgjort til fullt integrerte AUF-ere, og her gikk bygging av vennskap og politisk skolering hånd i hånd. I 2014 var derfor årene uten Utøya som arena for dette begynt å bli et stort problem både for AUFs identitet og organisasjonsbygging. 
En av hindringene for ny sommerleir på Utøya var kontroversen knyttet til kafébygget, et stort bygg sentralt plassert midt på den lille øya, som hadde vært det sentrale møte-, samlings- og serveringstedet. Kafébygget var også arena for viktige politiske begivenheter, og det var her Gro Harlem Brundtland talte om formiddagen 22. juli 2011. Som åsted for 13 brutale drap var det imidlertid vanskelig å se for seg at bygget kunne få tilbake disse opprinnelige funksjonene. For noen var lillesal og storsal allerede blitt «hellige steder»: steder for hedring av minnene til de som ble drept der, og ikke noe annet. Flere argumenterte derfor for at bygget måtte fredes, eller i hvert fall bevares i uendret form. Andre igjen fryktet at en full bevaring ville «fryse» bygget og dermed også øya som et åsted slik den var etter terroristens redselsgjerninger. En slik løsning, trodde mange AUF-ere, ville umuliggjøre Utøya som politisk leirsted og dermed i realiteten bidra til å fullføre terroristens verk.

Ved gjentatte besøk inne i bygget delte AUF-ere sine historier fra 22. juli, og gradvis ble det klart for oss at bygget ikke utelukkende var et sted for død. Det var også et sted for overlevelse, for omsorg, og for flukt. Særlig tydelig ble dette i møtet med fortellingen til AUF-er og sentralstyremedlem Hilde Firman Fjellså 27. mai. Inne på toalettet hvor hun hadde søkt tilflukt, fortalte hun sin historie om hvordan noen spinkle toalettbåser ble redningen for henne og 17 andre leirdeltakere. Mange fortalte også hvordan de reddet livet ved å bruke bygget som en fluktrute fra teltplass, videre ut vinduene og derfra til fjorden eller til skjulesteder rundt på øya. Død, skjulested eller flukt var de tre alternativene som gjaldt den dagen, og gradvis så vi hvordan de ulike historiene og skjebnene fra ulike deler av øya i konsentrert form var representert inne i selve kafébygget. Det samme var solidariteten og den grenseløse omsorgen som ungdommene viste for hverandre den dagen, inne i kafébygget og rundt omkring på øya (Schau 2012). 
Gjennom mange og lange samtaler ble det klart både for oss og AUF-ledelsen at kafébygget og det bygget rommet av ulike skjebner og fortellinger, på en eller annen måte måtte bli en del av Utøyas nye liv og nye identitet. Ikke minst fordi vi her hadde et fysisk sted og en fysisk struktur som kunne romme minner og historier fra ulike deler av øya den dagen. På denne måten, håpet vi, ville også de øvrige delene av øya gradvis frigjøres fra hendelsene 22. juli. Dette ga desto større mening siden kafébygget også var det eneste stedet hvor de fysiske sporene etter denne beksvarte fredagen fremdeles var fysisk synlige.

Basert på denne tenkningen og inspirert av Hildes historie skisserte arkitekt Blakstad Haffner på en workshop neste dag en løsning hvor de mest berørte og sentrale delene (flukt, skjulested og åsted) av kafébygget skulle bevares, men de øvrige delene ble foreslått revet. Blakstad Haffner foreslo videre å bygge en ny bygningskropp som dels skulle hegne om de bevarte delene, dels skape rom for fremtidsrettet historiefortelling, læring og refleksjon. Senere samme dag ble skissen presentert for Jørgen Frydnes, Eskil Pedersen og Mari Aaby West, som alle ga sin tilslutning til idékonseptet som lå bak. Forslaget betød at AUFs tidligere planer om en rivning av kafébygget måtte omgjøres til fordel for bevaring av lillesal, deler av storsal, korridor og toalettområder, samt bygging av et nytt omkransende bygg. Det nye grunnkonseptet ble vedtatt av et enstemmig sentralstyre, og 2. juli 2014 ble de endrede planene for kafébygget presentert i en kronikk og et lengre intervju i Aftenposten med Eskil Pedersen. Her slo AUF-lederen fast at de i 2012 hadde vært for tidlig ute, og at de nå i 2014 hadde funnet fram til en bedre og mer balansert løsning hvor både pumpehuset og deler av kafébygget skulle bevares (Aftenposten 2014). Både innrømmelsene og det nye konseptet ble godt mottatt blant de berørte og i offentligheten. En videre bearbeiding av konseptet ble presentert for NRK, TV 2 og Dagbladet 1. september samme år. 
Etter ønske fra AUF deltok her også direktør ved 9/11 Memorial Museum Alice Greenwald for å bidra til troverdighet blant berørte og i offentligheten (Greenwald 2014).

\section{Forskningsetikk og metode - noen refleksjoner}

«July 22 and the negotiation of memory» har fra starten vært et kvalitativt orientert prosjekt, og den fleksibiliteten som ligger i dette metodevalget, har vært avgjørende for å kunne tilpasse datainnsamlingen for de ulike minneprosessene. Ikke minst gjelder dette for prosessen på Utøya, hvor aktiv deltakelse var vår billett til innsiden av en prosess som var skjør og i stor grad lukket for andre enn de berørte familiene og AUF.

Fordi AUFs behov for faglig bistand var premisset som muliggjorde vår forskning, var det nødvendig å avklare om rollene som forskere og rådgivere kunne kombineres, hvordan dette i så fall kunne gjøres, og hvilke implikasjoner dette ville ha for oss som forskere og som rådgivere. Her ble det viktig å la seg informere om mulighetsrommet som ligger i ulike relasjonsbaserte forskningsmetoder som aksjonsforskning og deltakende observasjon. Like viktig som valg av metode var imidlertid den etiske dimensjonen. Dels dreide dette seg om overordnede retningslinjer, dels om behov for en etisk praksis som var holdbar i vår interaksjon med de involverte på en dag til dag-basis. Jevnlig skulle vi komme opp i det som sosiologene Guillemin og Gillam definerer som «etisk viktige øyeblikk» (ethically important moments) hvor skjøre situasjoner krevde en sensitivitet og en respons som ikke kunne detaljplanlegges (Guillemin \& Gillam 2004). Etikk og metode er aldri ett, heller ikke i vårt prosjekt, men både i første fase og jevnlig underveis opplevde vi hvor tett etikk og metode virket sammen. I dette avsnittet har jeg derfor valgt å fokusere på samspillet mellom metode og 
etikk og hvordan dette gikk som en rød tråd gjennom arbeidet vårt på Utøya.

AUF-erne vi samarbeidet med, var alle direkte berørt. De hadde alle enten vært på øya 22. juli, eller de hadde mistet noen som sto dem nær. Da vi innledet arbeidet vårt, hadde disse ungdommene tre krevende år bak seg. På denne tiden var det også flere stemmer i den norske offentligheten som ga uttrykk for at Utøya og 22. juli hadde en nasjonal betydning langt utover hensynet til en politisk ungdomsorganisasjon, og at ansvaret for den videre prosessen burde overlates til andre. Dette bidro til økt spenningsnivå innad i AUF, og til at en vanskelig situasjon ble vanskeligere.

Presset som organisasjonen hadde på seg, var også tydelig da vi, i forbindelse med formaliseringen av vår rådgiverrolle, 25. februar 2014 første gang møtte en samlet AUF-ledelse. Fram til da hadde vi primært forholdt oss til Frydnes og Aaby West, som vi etter åtte måneders dialog med hadde en avklart relasjon til. For flere av de andre i AUF-ledelsen, som Eskil Pedersen, Marianne Wilhelmsen og Åsmund Aukrust, var dette første møte med oss. Spørsmålene var derfor mange om våre motiv, vår kompetanse og vår rolleforståelse. Min respons var å være tydelig på at vi gjennom våre internasjonale partnere hadde kompetanse som ville være viktig og kanskje avgjørende for å få til gode løsninger på en situasjon som hadde blitt stadig mer kompleks. På den annen side var jeg like tydelig på at det var AUF selv som i dialog med de berørte og innad i egen organisasjon måtte gjøre valgene og ta de grep som trengtes for å komme tilbake til Utøya. En lignende situasjon oppsto tre måneder senere da hele ressursgruppen (unntatt Alice Greenwald) i mai 2014 var i Oslo for å møte et samlet sentralstyre. Flere av styremedlemmene hadde på dette tidspunktet i liten grad vært involvert i det interne arbeidet som pågikk, og for mange sto forståelsen fra 2011-2012 om at kafébygget måtte rives, fremdeles sterkt. Det var derfor nok en gang spenning i rommet knyttet til vårt prosjekt 
og vår agenda. Åpningsreplikken fra James Young under møtet: «We are not here to tell you what to do, we are here to keep you company» formidlet imidlertid en rolleforståelse fra vår side hvor det kom tydelig fram at eierskapet i prosessen måtte ligge hos AUF. Begge disse eksemplene var «etisk viktige øyeblikk» hvor det var avgjørende at mennesker i en allerede krevende situasjon ikke skulle bli tilført en merbelastning som følge av vår tilstedeværelse. I disse to konkrete tilfellene lyktes vi i å agere situasjonsbestemt på måter som skapte trygghet og ivaretok AUF-ernes autonomi og integritet. Slike hendelser hadde imidlertid også metodiske implikasjoner ved at AUF-erne i tillegg til å være informanter for det faglige arbeidet også tok en deltakende og aktiv rolle i prosessen. I løpet av kort tid gikk de involverte AUF-erne derfor fra å være forskningsobjekter til å bli forskningsdeltakere. Dette ga en rolleavklaring og en trygghet som også gjorde at vi som forskere kunne være tydelige på faglige vurderinger som ikke nødvendigvis ble delt av alle i AUF.

I ettertid har jeg av flere blitt spurt om vi drev aksjonsforskning på Utøya, altså forskning hvor forskeren selv kommer med forslag til endringstiltak, deltar i gjennomføringen av tiltakene og kontrollerer virkningen av dem (Coughlan \& Brydon-Miller 2014). I én forstand er dette riktig, da vi fra vår posisjon på innsiden av prosessen var mer å regne som bevegende aktører enn som passive observatører. Mens mye av det som omtales som aksjonsforskning, tar utgangspunkt i konkrete ønsker om endring innenfor et etablert praksisfelt (som skoleverk og helsevesen), var situasjonen på Utøya mer åpen og med et utall mulige utfall. På den ene side var utfordringene konkret avgrenset til et spesifikt geografisk sted og til en organisasjon som eier, på den annen side ville alle valg ha innvirkning for flere tusen berørte og for den videre håndteringen av et traume som angikk en hel nasjon. Vi var klare på at ny aktivitet på Utøya måtte bygge på en bevissthet og ærlighet rundt det som 
skjedde 22. juli, men utover dette hadde vi ingen forhåndsdefinerte forslag til tiltak og metodikk. Vi visste at vår inntreden ville ha en effekt, men ikke hvilken.

Vår involvering i Utøya-prosessen 2013-2014 synes for meg derfor å ha flere berøringspunkter med deltakende observasjon, en metode særlig utbredt i sosialantropologi og i deler av sosiologifaget (Fangen 2010). I deltakende observasjon er hovedgrepet som forsker å være til stede i forskningsobjektenes verden. Dette for å få en innlevelse og en kjennskap fra innsiden som en vanskelig kan få fra utsiden. Et konkret eksempel på dette var vår gradvis øte forståelse av AUF som en livsfaseorganisasjon hvor medlemskap, aktivitet og identitet knyttet til organisasjonen gjelder for noen korte, men gjerne svært intense ungdomsår. Dette ga oss som voksne ikke-AUF-ere en dypere forståelse av tidsdimensjonen i prosessen og av behovet for å komme tilbake innenfor en tidsramme som ville muliggjøre den historie-, identitets- og erfaringsoverføring mellom nye AUF-ere og eldre AUF-ere som alltid har vært en så sentral del av sommerleirene på Utøya.

Gjennom vår deltakelse på Utøya var vi involvert i komplekse og krevende samhandlingsprosesser samtidig som vi gjennom feltnotater skulle dokumentere prosessen. Et dilemma i dette var at vår tilstedeværelse påvirket både prosess og utfall. I mange typer følgeforskning er nærheten til prosess og aktører en utfordring. Ved deltakende observasjon kommer i tillegg utfordringen ved at en som forsker også er medprodusent av de kilder og data som utgjør analysematerialet. Nærheten til de innsamlede observasjonene åpner for flere innganger til forståelse av kompleksiteten og de ulike delene i prosessen som virket sammen. På den annen side kan vi si at den samme nærheten påvirker eller «forurenser» observasjonene på måter som svekker deres verdi som basis for forklaringer med overføringsverdi til andre og lignende situasjoner. Det er derfor trolig riktig å si at våre observasjoner av prosessen på Utøya 
har større verdi som dokumentasjon av en på mange måter unik prosess enn som utgangspunkt for generaliserende teoribygging.

Nærheten til prosessen og aktørene økte imidlertid vår årvåkenhet og vår følsomhet. Dette ga oss en dypere forståelse av prosessens mange sammensatte og motstridende hensyn enn det som ellers kom fram i mediene og offentligheten. Vi fikk også økt bevissthet rundt viktigheten av å lytte fremfor å snakke. En annen gevinst av nærhet og gjensidig tillit var en bredere inngang til og et økt tilfang av tolkningsmateriale. Jevnlig fikk vi informasjon og kunnskap som ikke finnes nedfelt i offisielle dokumenter, og som neppe heller ville kommet fram i en ordinær intervjusituasjon. Det var for eksempel en sterk opplevelse å observere hvordan flere AUF-ere slet med å snakke om Utøya og slet med å være på Utøya. Dette samtidig som de deltok iherdig i arbeidet med å komme tilbake til Utøya både av hensyn til sine drepte venner og av hensyn til nye AUF-ere.

Som forskere flest forsker og skriver vi primært for et smalt og avgrenset faglig fellesskap. Det har derfor vært et privilegium å oppleve at vår humaniorabaserte faglighet i en kritisk fase for mange har hatt en praktisk og konkret betydning. Tilliten og de nære relasjonene til AUF spesielt, men også til berørte, har videre gitt oss adgang til arenaer, diskusjoner og prosesser som ganske sikkert ellers ville forblitt stengt for innsyn utenfra. Forskningsmessig har prosjektet gjennom perioden 2013-2014 på Utøya fått flere lag av kompleksitet siden deler også vil måtte romme dokumentasjon og analyse av egen intervensjon. Det er ikke gitt at alle enkelthetene i våre beskrivelser og opplevelser vil deles av AUF, og i tillegg innebærer analyse at en tilfører noe mer til det en har sett og hørt. Arbeidet med å omgjøre observasjoner og notater til analyser som skal bli en del av fagfeltet nasjonalt og internasjonalt, blir derfor krevende og vil måtte kvalitetssikres gjennom tett involvering av fagfeller. Prosjektets bidrag til minnestudier som fagfelt blir derfor 
dels våre egne analyser, dels tilgjengeliggjøring av et materiale som forhåpentlig også kan inngå i fremtidige forskningsprosjekter til andre forskere.

\section{Avslutning}

Under terrorangrepet og i timene etter tok ungdommene i AUF ansvar for hverandre. Allerede dagen etter var de også tydelige på at de ville ta ansvar for AUF som organisasjon og for Utøya som en del av AUFs fremtid. Da Utøya i august 2015 ble gjenåpnet for sommerleir, var det et resultat av en fire år lang og svært krevende prosess. Åpningen fant sted foran et stort nasjonalt og internasjonalt pressekorps og med 1300 påmeldte deltakere, mens det til sammenligning i 2011 var drøye 600 deltakere. Oppslutningen vitnet om en organisasjon som hadde klart seg gjennom nesten umenneskelige prøvelser, og også om en ungdomsgenerasjon som i årene etter 22. juli 2011 valgte å møte terror og vold med økt politisk og samfunnsmessig engasjement. ${ }^{4}$

I 2013-2014 bisto vi, etter invitasjon fra AUF, i arbeidet med å balansere behovet for minne og nytt liv for Utøya som helhet, og mest konkret i arbeidet med å finne en balansert løsning for kafébygget, hvor 13 ungdommer ble myrdet 22. juli 2011. En sentral del av vår oppgave i dette var å gi «input» fra håndtering av sammenlignbare prosesser andre steder, å åpne et handlingsrom hvor AUF innad og i dialog med de berørte kunne tenke nytt. I løpet av prosessen opplevde vi at AUFs forståelseshorisont ble utvidet, og at de fikk sett seg selv i et internasjonalt speil med gjenkjennbare mønstre og dilemmaer. Ett drøyt år med tett dialog mellom oss og i første rekke AUF, men også etter hvert med berørte og den

4 I 2011 hadde AUF 9600 medlemmer. I 2015 er tallet 14000 medlemmer. Også de andre ungdomspartiene i Norge har etter 2011 hatt en markant vekst i antall medlemmer. 
nasjonale støttegruppen etter 22. juli, la grunnlag både for bredere forankring og for at planene for «Nye Utøya» på en mer balansert måte ivaretok de ulike hensynene. I løpet av sommeren 2014 ble de første skissene av Hegnhuset, et minne- og læringssenter som skal bygges rundt og beskytte de berørte delene av kafébygget, presentert i ulike settinger. Samtidig, og uten vår medvirkning, foregikk en prosess med å etablere et minnested for de berørte på en mer avskjermet del av øya. ${ }^{5}$ Minnestedet «Lysningen» ble innviet på fireårsdagen for terroren, 22. juli 2015, mens minne- og læringssenteret ble åpnet sommeren 2016. At AUF i samarbeid med de berørte, og med bistand fra vår forskergruppe, tok grep for å ivareta og balansere behovene for både minne og nytt liv, bidro til at mange av kontroversene stilnet, og til at øya igjen er arena for sommerleirer for unge AUF-ere fra hele Norge.

\section{Referanser}

Aftenposten (2013). AUF utsetter riving på Utøya. 17.06.2013 http:// www.aftenposten.no/nyheter/iriks/politikk/AUF-utsetter-riving-paUtoya-7232539.html

Aftenposten (2014). AUF snur - lar deler av kafébygget på Utøya stå. 02.07.2014. http://www.aftenposten.no/nyheter/iriks/politikk/AUFsnur---lar-deler-av-kafbygget-pa-Utoya-sta-7623550.html

AUF til etterlatte (2012). http://22juli.info/admin/brukerdokumentasjon/ Dokumenter\%20som\%20linkes/Utøya\%20arrangementet\%2022\%20 \%20juli\%202012.pdf

Coughlan, D. \& Brydon-Miller, M. (2014). The SAGE Encyclopedia. Dagbladet (2012). Eskil Pedersen kan glemme gjenreising av Utøya. Den øya bør fredes. 07.09.2012. http://www.dagbladet.no/2012/09/07/ nyheter/utoya/22_juli/auf/23295038/

5 Minnestedet for de berørte er lagt til en avskjermet og ikke tidligere brukt del av Utøya. Stedet er blitt til i tett samspill mellom berørte, AUF, et eget minnestedsutvalg ledet av kunstner Marianne Heier og ${ }_{3}$ RW Arkitekter, som har stått for utformingen. 
Doss, E. (2008). The Emotional Life of Contemporary Public Memorials. Towards a Theory of Contemporary Memorials. Amsterdam: Amsterdam University Press.

Etterlatte til AUF (2012). Brev fra en gruppe etterlatte til daværende statsminister Jens Stoltenberg, AUF samt flere statsråder. 22. juliminnesmarkeringen på Utøya. Gjengitt i VG 31.05.2012. http:// www.vg.no/nyheter/innenriks/terrorangrepet-22-juli-ofrene/ les-de-etterlattes-brev-til-statsministeren/a/10054028/

Fagerland, T.E. \& Nilssen, T.R. (2011). The Norwegian Fascist Monument at Stiklestad 1944-45. I: Bjerg, H., Lenz, C. \& Thorstensen, E. (Red.) Historicizing the Uses of the Past: Scandinavian Perspectives on History Culture, Historical Consciousness and Didactics of History Related to World War II. (77-90). Bielefeld: Transcript Verlag.

Fagerland, T.E. (2013). Fra monument og minnesmerke til minnested: ny bruk av offentlige rom. I: Kunstplan for minnesteder etter 22. juli. (36-39). Oslo: Koro.

Fagerland, T.E. (2014a). Between Patriotism and Univeralism: Norwegian World War II Monuments and Memorials 1990-2014 from a Transnational Perspective. I: Bauerkämper, A., Fure, O.B., Hetland, $\varnothing$. \& Zimmermann, R. (Red.) From Patriotic Memory to a Universalistic Narrative? (215-232). Essen: Klartext Verlag.

Fagerland, T.E. (2014b). Monuments and painful history: Steileneset Memorial. An international perspective. I: Andreassen, R.L. \& Willumsen, L.H. (Red.) Steilneset Memorial. Art Architecture History. (77-88). Stamsund: Orkana Forlag.

Fagerland, T.E. \& Hjorth, I. (2016). Remembering traumatic pasts - Movements in the memorial landscape of Norway. I: Guttormsen, T.S. \& Swensen, G. (Red.) Heritage, Democracy and the Public. (7-38). Surrey: Ashgate. Fagerland, T.E. (2016). July 22 and the negotiation of memory in Norwegian society 2011-2014. I: Guttormsen, T.S. \& Swensen, G. (Red.) Heritage, Democracy and the Public. (s. 71-83). Surrey: Ashgate. Fangen, K. (2010). Deltagende observasjon, 2. utgave. Oslo: Fagbokforlaget. Greenwald, A.M. (2014). Å minnes med liv: Utøya og Ground Zero.

Dagbladet 24.09.2014. http://www.dagbladet.no/2014/09/24/kultur/ meninger/utoya/ground_zero/911/35416036/

Guillemin, M. \& Gilam, L. (2004). Ethics, Reflexitivity, and «Ethically Important Moments» in Research. Qualitative Inquiry, 10 (2), 261-280. 
Kverndokk, K. (2012). «I kveld er gatene fylt av kjærlighet»: Om spontane minnesteder, communitas og rituell renselse etter 22 . juli 2011. I: Beckman, S. (Red.) Kulturaliseringens samhälle. Problemorienterad kulturvetenskaplig forskning ved Tema $Q$ 2002-2012. (191-197). Linköping: Linköping universitet.

Linenthal, E.T. (2001a). The Unfinished Bombing: Oklahoma City in American Memory. New York: Oxford University Press.

Linenthal, E.T. (2001b). Preserving Memory: The Struggle to Create America's Holocaust Museum ( $2^{\text {nd }}$ ed.). New York: Colombia University Press.

Magnusson, M. (2016). «Samlet. Et norsk minnelandskap etter terrorhandlingene». Masteroppgave i kulturminneforvaltning. Trondheim: NTNU.

Margry, P.J. \& Sánchez-Carretero, C. (Red.) (2011). Grassroots Memorials: The Politics of Memorializing Traumatic Death. Basingstoke, New York-Oxford: Berghahn Books.

NRK (2012). Slik skal AUF gjenreise Utøya. 07.09.2012. http://www.nrk. no/norge/slik-skal-auf-gjenreise-utoya-1.8312721

Pedersen, E. (2011). AUF lar seg ikke true til taushet. NRK 23.07.2011. http://www.nrk.no/norge/_-auf-lar-seg-ikke-true-til-taushet1.7723819

Riksantikvaren (2012). Utøya - Fredning - Riksantikvarens holdning. Svarbrev til etterlatte. 09.10.2012. http://22juli.info/admin/ Brukerdokumentasjon/Dokumenter\%20som\%20linkes/Svarbrev\%20 -\%20Sp\%C3\%B8rsm\%C3\%A5l\%20om\%20fredning\%20-\%20\%20 Ut\%C3\%B8ya.pdf

Schau, K. (2012). Rettsnotater. 22. juli-rettsaken, Oslo tinghus 2012, Oslo: No Comprendo Press.

Styringsgruppen for minnesmerker/minnemonumenter (2012). Steder for å minnes og påminnes - innstilling vedrørende minnesteder etter 22. juli. Oslo: Kulturdepartementet. https://www.regjeringen.no/ globalassets/upload/KUD/Kunstavdelingen/Rapporter_Utredninger/ Steder_for_aa_minnes_og_paaminnes_22juli.pdf.

Suleiman, S. (2008). Crisis of Memory and the Second World War. Harvard: Harvard University Press.

TV 2 (2012). Utøya er vårt Auschwitz. TV2.no 25.09.2012. http://www. tv2.no/a/3885800 
Valebrokk, K. (2012). Reis ingen monumenter. Aftenposten 29.04.2012. http://www.aftenposten.no/meninger/kommentarer/Reis-ingenmonumenter-6817093.html

Young, J.E. (2006). The Stages of Memory at Ground Zero. I: Stier, O.B. \& Landres, J.S. (Red.). Religion, Violence, Memory and Place (s. 214-234). Bloomington: Indiana University Press.

Young, J.E. (2000). Germany's Holocaust Memorial Problem - and Mine. I: Young, J.E. At Memory's Edge: After-images of the Holocaust in Art and Architecture. (s. 184-223). New Haven \& London: Yale University Press. 


\section{KAPITTEL 7}

\section{Etiske utfordringer $\mathrm{i}$ ekstremismeforskningen i Norge}

\section{Lars Gule ${ }^{1}$}

In this chapter, five ethical challenges in research on extremism are discussed. First, how to take into consideration the interests of survivors of terrorist attacks and their dependants in order to avoid re-traumatisation. Second, the collection and treatment of sensitive personal data in research on extremists, as even (suspected) extremists have a right to privacy. Third, the duty to prevent harm if the researcher learns about planned violent crimes during his/her research. Fourth, the danger of researchers in aiding extremists in clarifying their ideology. Fifth, the danger of researchers aiding extremists and terrorists in developing their violent strategies. All these challenges are serious. They could indicate that research on extremism should be avoided all together. However, knowledge about extremists and their extreme ideologies and strategies are needed in order to prevent violence and terrorism, and research will be carried out regardless - especially by various security services.

1 Førsteamanuensis, Institutt for internasjonale studier og tolkeutdanning, Høgskolen i Oslo og Akershus 
Such investigations will most often be classified. Thus, it will be unknown to the public. In an open and democratic society, research based knowledge should be available to the community as it is this public, which will be ultimately responsible for counter-extremism and counter-terrorism policies. Accordingly, open and accessible research on extremism outweighs the disadvantages and possible pitfalls of such research as researcher have a responsibility to inform the public about various aspects of extremism.

\section{Innledning}

De etiske utfordringene ved forskning på ekstremisme og ekstremister ble tydelige da Anders Behring Breivik vinteren 2013-2014 sendte ut invitasjoner til et knippe forskere og tilbød dem å intervjue ham. De nasjonale forskningsetiske komiteene ville sette søkelys på en del av utfordringene disse henvendelsene representerte, gjennom et seminar i april 2014 (De nasjonale forskningsetiske komiteene 2014; Severinsen 2014). Ville det være riktig å formidle terroristens synspunkter til et større publikum, om enn i en forskningsmessig relevant sammenheng? Hva med hensynet til de pårørende som vil trekke et glemselens slør over hele mannen og alt han står for?

Slike forskningsetiske problemstillinger er likevel bare noen av flere som dukker opp i forskningen på ekstremisme og ekstremister. I dette kapittelet vil jeg se nærmere på følgende fem hovedutfordringer:

- Hensynet til overlevende og pårørende for terrorhandlinger

- Personvern når det forskes på ekstremister

- Avvergingsplikten

- Faren for å hjelpe ekstremister i å avklare sin ideologi

- Faren for å hjelpe ekstremister og terrorister i å utvikle sine voldsstrategier 
Dette er ikke de eneste problemstillingene som er relevante. Mye av forskningen foregår på/via Internett, noe som reiser egne utfordringer (Buchanan og Zimmer 2012). Viktige utfordringer som heller ikke drøftes, er bruken av skjult observasjon - som bruk av falske profiler på Internett eller falsk identitet ved rekruttering til intervjuer, eller "provokasjoner» gjennom intervensjoner i ekstreme miljøer på nett eller i fysisk forstand, blant annet gjennom falske profiler/identiteter. Slike tilnærminger kan gi verdifull informasjon, men er ved første øyekast i strid med mange forskningsetiske regler, som informert samtykke, mulighet til å reservere seg, informasjon om resultater og publisering (Bikson mfl. 2007, von Hippel 2015, men også Reynolds 2012). Heller ikke spørsmål om etiske utfordringer gjennom den risiko forskerne selv utsettes for i kontakt med ekstremister, tas opp her (men se Lee-Treweek og Linkogle 2000 og Speckhard 2009 for mer om dette).

I dette kapittelet forstås ekstremisme som en videre kategori enn terrorisme, men slik at all terrorisme er former for ekstremisme, mens alle former for ekstremisme ikke nødvendigvis fører til terrorisme.

\section{Ofre og pårørende}

Den første problemstillingen er generell fordi det alltid vil være ofre og etterlatte etter terrorhandlinger som kan få revet opp mentale sår, noen ganger lang tid etter hendelsene. I Norge er problemstillingen viktig når det gjelder forskning på terrorhandlingene 22 . juli 2011. Mange av de overlevende og pårørende etter ofrene ønsker minst mulig omtale av Breivik. De ønsker å glemme ham og det han står for. Dette er et legitimt ønske og noe forskere også må forholde seg til. Men hvordan?

Det er fortsatt mye å lære om terrorhandlingene 22. juli 2011, selv om det foreligger et omfattende kompendium som beskriver 
en del av motivene og framgangsmåten. Slik utvidet kunnskap kan være viktig for å forstå og for å forebygge. Av samme grunn er det også behov for forskning som ikke kan utelukke intervjuer eller samtaler med Breivik. Flere detaljer i hans motivasjon og hva som påvirket ham i tiden fram til terrorhandlingen, samt mer kunnskap om hvordan han har videreutviklet sin ideologiske posisjon, er av faglig interesse. Dette var bakgrunnen for at professor Øystein Sørensen og jeg selv sa ja til å møte Breivik. ${ }^{2}$

For å forminske de uønskede effektene dette kan ha for ofre og pårørende, er det behov for et godt samarbeid mellom forskeren eller forskerne og støttegruppen for pårørende. Et slikt samarbeid skal selvsagt ikke føre til at de overlevende og pårørende skal avgjøre hva det skal forskes på, og hvordan dette skal gjøres, men det er rimelig at forskere tar hensyn til de sterke følelsene denne typen forskning kan resultere i ved publisering. Særlig når formidling av forskningsresultatene kan nå et bredt publikum.

For professor Sørensen og meg selv var det også avgjørende at ikke Breivik skulle styre vår forskning, verken ved å legge urimelige begrensninger på hva vi kunne spørre om, eller ved å kreve innflytelse på valg av terminologi eller formuleringer av funn når vi skulle publisere. Dette ga vi uttrykk for på en slik måte at dette ble offentlig kjent, blant annet via det seminaret i april 2014 som inspirerte dette kapittelet. Dette var trolig en medvirkende grunn til at Breivik avbrøt kontakten med oss.

De fleste forskere vil formidle sin forskning i fagartikler, rapporter og/eller bøker. Disse har tradisjonelt et begrenset nedslagsfelt - i hovedsak fagfeller - og vil derfor i beskjeden grad berøre ofrene for terror. Men når det gjelder Breiviks terrorhandling i Norge, framstår

2 Sørensen og jeg er begge med i Nettverk for studier av totalitarisme og demokrati (NEST), se http://www.hf.uio.no/iakh/forskning/nettverk/totalitarisme/ for mer informasjon. 
denne som så spesiell at også forskning på og omkring handlingen og terroristen selv vil vekke stor interesse i en rekke medier i mange år framover. Derfor er det all grunn til å tro at denne forskningen vil ha et langt bredere nedslagsfelt og derfor også sterk påvirkning på befolkningen enn det meste av annen og beslektet forskning. Det finnes belegg for dette i forskning på etterlatte etter 11. septemberangrepet 2001 (Christ 2010, Stovall-McClough og Cloitre 2006). Det viste også oppmerksomheten som Breiviks invitasjon til forskere fikk i mediene, og interessen for seminaret til De nasjonale forskningsetiske komiteene i april 2014.

På den andre siden er det mulig at også ofrene for islamistiske terrorhandlinger i utlandet, men med utspring i Norge, kan oppleve forskning på norske ekstreme islamistiske terrorister tilsvarende belastende, særlig ved publisering i internasjonale kanaler, om enn vi ikke har eksempler på dette til nå. Derfor bør problemstillingen også ses mer generelt enn bare knyttet til Breiviks handlinger. Spørsmålet blir dermed hvordan man kan ta tilbørlig hensyn til ofre og pårørende for terror uten at dette går ut over forskningens målsettinger og integritet.

Det enkleste svaret er trolig at man informerer ofre og pårørende om pågående forskning og forestående publisering, hvis mulig. I den norske konteksten omkring Breiviks terror vil formidling gjennom støttegruppen være en aktuell tilnærming. Det vil neppe være like enkelt å informere og eventuelt koordinere med ofre utenfor Norges grenser, men det bør kanskje forsøkes likevel.

Videre vil dette handle om presentasjonen av forskningsmaterialet. Det vil trolig være måter å beskrive hendelsesforløp og forskningsfunn på som er mer belastende enn andre. Her vil det være forskningsformålet som må ligge til grunn, men ingen forsker har fullmakt til å opptre urimelig hensynsløst.

Den etiske vurderingen i denne sammenheng innebærer en avveining av to hensyn - behovet for ny kunnskap mot ofre og pårørendes 
behov for å legge hendelsen bak seg, blant annet for å hindre retraumatisering. Det er ingen enkel avveining, og det er neppe mulig å gi et fasitsvar. Men forskere kan i alle fall ikke ignorere hensynet til ofre og pårørende i sin jakt på kunnskap og forståelse.

\section{Personvern}

Kunnskap om hvem som blir ekstremister, er viktig for å kunne forklare hvordan og hvorfor ekstremiseringsprosessen skjer. "Hvem» i denne sammenheng dreier seg om innsikt i sentrale sosioøkonomiske variabler som etnisk opprinnelse/tilhørighet, familiebakgrunn, utdanning, økonomisk status, arbeidsforhold, (psykisk) helse og kriminalitet. Svar på «hvordan» og «hvorfor» krever at vi også må kunne forstå motiver, blant annet på bakgrunn av politisk-ideologisk og/eller religiøs overbevisning og aktivitet. Alt dette er personopplysninger, mange av dem av sensitiv art. I norsk sammenheng er nærgående studier av Breiviks barndom og forholdet til moren eksempler (Borchgrevink 2012; Christensen 2013). Internasjonalt foreligger det flere studier av islamistiske terrorister hvor også psykisk helse tematiseres (for eksempel Sageman 2004; Bakker 2006).

I Norge er behandling av personopplysninger, herunder sensitive opplysninger, lovregulert (jf. personopplysningsloven $\$ \$ 8$ og 9). Personopplysninger skal ikke brukes eller spres i forbindelse med forskning uten at flere hensyn er tatt. Anonymisering av informanter og de det forskes på, er viktig og står også sentralt i en rekke forskningsetiske regler, nasjonalt og internasjonalt (NESH 2016, AoIR 2002, AoIR 2012, British Sociological Association 2002; se også van Gorp 2013). I det følgende ser jeg nærmere på (1) anonymitet og anonymisering og (2) fritt og informert samtykke.

Det kan være vanskelig å sikre anonymitet når man forsker på små utvalg, som man gjerne gjør i mye av forskningen på ekstreme 
holdninger og handlinger. I mindre og gjennomsiktige samfunn kan en enkelt forskningsmessig viktig opplysning være tilstrekkelig til å identifisere en person. Dette skal i prinsippet unngås. På den andre siden vil ofte personer med ekstreme holdninger - som fremmedkrigere - allerede være kjent i lokalmiljøet. Men om personene ikke er kjent i sine miljøer, kan forskere komme til å bidra til en svært uheldig stigmatisering av personer, nettopp fordi personene identifiseres med svært omstridte normer og verdier (van Gorp 2013; Speckhard 2009).

I forbindelse med rettssaker blir også mye kjent om personers bakgrunn og motiver. Dette gjelder for en del tiltalte fra både ekstreme islamistiske og høyreekstreme miljøer. En del av dette stoffet blir presentert for allmennheten gjennom medienes referater - og slett ikke alltid anonymisert.

Det er derfor både et paradoks og et dilemma at journalister kan samle og presentere stoff om ekstremister som forskere ikke like enkelt kan samle, sammenstille og presentere. For forskere vil en slik sammenstilling med sensitive personopplysninger også fra åpne og tilgjengelige kilder som presse og sosiale medier i utgangspunktet kreve konsesjon, dvs. tillatelse fra Datatilsynet (jf. personopplysningsloven $\$ 33$ ), med mindre det foreligger en tilråding fra et personvernombud (jf. personopplysningsforskriften $\$ 7-27$ ). Og selv når personopplysningene ikke er sensitive, kreves det informert samtykke fra dem det forskes på (personopplysningsloven $₫ 8$; se også De nasjonale forskningsetiske komiteene 2006). I prinsippet er ikke dette et urimelig krav, men det vil i praksis kunne gjøre det umulig å gjennomføre relevant forskning fordi det ikke er mulig å innhente det informerte samtykket. Det kan være flere grunner til dette, men det er opplagt vanskelig å komme i kontakt med personer som befinner seg i en krigssone, som de norske fremmedkrigerne i Syria og Irak, eller som allerede er døde (uten at dette er offisielt bekreftet). Videre kan en rekke personer - som hjemvendte 
fremmedkrigere - velge å gå under jorda, dvs. gjøre seg utilgjengelig for kontakt med forskere og andre, fordi de ikke ønsker oppmerksomhet eller å bli oppdaget av politi og påtalemyndighet, som jo kan forventes å fremme tiltaler mot dem for støtte til eller deltakelse i en terrorgruppe. Det siste forholdet gjør det også vanskelig for forskere å få gjennomført intervjuer med hjemvendte fremmedkrigere, men dette er mer av en kildeutfordring og et eventuelt metodeproblem (se Hemmingsen 2011).

Dilemmaet $\mathrm{i}$ denne forbindelse består $\mathrm{i}$ at forskere gjerne vet mye fordi de har lest aviser, gått gjennom Facebook-profiler og -kommentarer, vært til stede under rettssaker, har snakket med noen av ekstremistene, og så videre, men ikke har anledning til å systematisere denne kunnskapen (andre steder i enn i eget hode) og presentere den i form av tabeller og analyser fordi dette er sensitiv personinformasjon. Samtidig er kunnskapen samfunnsmessig viktig skal man kunne bidra til forebygging av ekstremisme og ekstreme handlinger. Forsvarets forskningsinstitutt (FFI) har forsøkt å få tillatelse fra Datatilsynet til å sammenstille informasjon fra åpne kilder, dvs. avisartikler, intervjuer, Facebook-sider og lignende. «Vi ønsket å systematisere informasjon som ligger ute på internett for å lage profiler på fremmedkrigerne», uttalte leder av et forskningsprosjektet om dette ved FFI, Thomas Hegghammer, til VG i august 2015 (Bergo 2015). Betingelsen Datatilsynet stilte for gjennomføring av prosjektet, med krav om at de registrerte fremmedkrigerne måtte informeres om at de ble forsket på, var umulig å innfri, mente miljøet ved FFI, blant annet fordi fremmedkrigerne i stor grad befinner seg utenfor rekkevidde $\mathrm{i}$ områder herjet av borgerkrig. Datatilsynet mente likevel dette ville være mulig å få til (Thon 2015). For FFI ble det imidlertid for tidkrevende.

Selv om det stilles andre krav i andre land, møter også internasjonale forskerkolleger utfordringen og må forholde seg til både 
nasjonal lovgivning og fagfeltets forskningsetiske retningslinjer (Reynolds 2012). Uansett, dilemmaet har ingen enkel løsning. For det er grunn til å ta personvernet på største alvor, samtidig som vi også har behov for solid kunnskap for å kunne motvirke ekstremisering. Det er derfor nødvendig å avklare forholdet mellom hensynet til informanten og behovet for forskningsbasert kunnskap. Dette er tematisert i forskningsetiske retningslinjer, men må altså vurderes både for hvert forskningsprosjekt og hver enkelt informant.

\section{Avvergingsplikten}

Dersom forskere får tilgang til informanter og kilder som er ekstremister, kan man også få kunnskap om begåtte eller planlagte ekstreme handlinger. Slike handlinger kan også dreie seg om alvorlige forbrytelser. Her dukker fort dilemmaet opp mellom avvergingsplikten og forskerens taushetsplikt overfor informanten.

Selv om hovedregelen i Norge er at man ikke har plikt til å melde fra til myndighetene eller andre dersom man får kunnskap om at en straffbar handling er i gjære, uten at man selv på noen måte medvirker til handlingen, finnes det unntak. $\$ 196$ i den nye straffeloven pålegger alle, under trussel om straff, en plikt til å avverge visse grovere forbrytelser. Dette gjelder for terrorisme, krigsforbrytelser, drap, seksuelle overgrep - særlig mot barn, kidnapping og grovere tilfeller av vold (Store norske leksikon og Elden 2015; se også Fossheim og Ingierd 2013). Mye av dette er ekstreme handlinger som for eksempel fremmedkrigere kan ha vært med på - eller som planlegges gjennomført i Norge eller andre steder. Dette gjelder derfor også handlinger i utlandet gjennomført av norske borgere eller en person med bosted i Norge (jf. straffeloven $₫ 5$ ).

Forskere har også en avvergingsplikt dersom han eller hun får kunnskap til konkrete terrorplaner, drap eller andre voldshandlinger. 
Det er likevel et relevant spørsmål hvor langt avvergingsplikten strekker seg, noe som også henger sammen med forståelsen av terrorbegrepet og -fenomenet. Sosiologen May-Len Skilbrei drøfter dette på en opplysende måte i sammenheng med egen forskning på prostitusjon og mulig menneskehandel (Skilbrei 2013). Det må med andre ord gjøres skjønnsmessige vurderinger.

Har man plikt til å (medvirke til å) forhindre at noen reiser til Syria for å slutte seg til jihad mot regimet i Damaskus? Har man plikt til å forhindre dette bare dersom man har opplysninger om at vedkommende potensielle fremmedkriger har valgt å reise til en organisasjon - for eksempel Jabhat al-Nusra eller Den islamske staten - som står på noen lands lister over terrororganisasjoner? Å slutte seg til en terrororganisasjon er etter norsk lov en alvorlig forbrytelse, med en strafferamme på inntil 10 år, jf. straffeloven $\$ \$$ 131-144. Men medlemskap i en gruppe innebærer ikke nødvendigvis at medlemmet vil begå terrorhandlinger. Det kan således reises alvorlige innvendinger mot omfanget av den norske terrorlovgivningen. Derfor reises det et dilemma om en forsker i en intervjusituasjon får kunnskap om at noen planlegger å reise til Syria. Er dette noe han eller hun har en lovpålagt plikt til å (bidra til å) avverge? Her kan situasjonen også variere fra land til land. (Britisk lovgivning er streng, og forskere risikerer for eksempel tiltale bare for å være i besittelse av materiale publisert av terrorister (Jones og Bhui 2008)).

For Norges del er det mulig å finne noe veiledning i Høyesteretts avgjørelse i saken Ulrik Imtiaz Rolfsen anla mot Den offentlige påtalemyndighet etter at PST beslagla upublisert filmmateriale hos ham i juni 2015. Politiet hadde under etterforskningen av en sak om overtredelse av straffeloven $1902 \$ 147 \mathrm{~d}$ foretatt beslag av upublisert filmmateriale hos Rolfsen. Han arbeidet med en film som skulle belyse hvorfor norske borgere lar seg verve som fremmedkrigere i Syria. Høyesterett opphevet beslaget. På den ene siden la Høyesterett ved 
avveiningen til grunn at vektige samfunnsinteresser tilsa at påtalemyndigheten fikk tilgang til materialet, mens det på den andre siden ble vist til at særlig sterke kildevernhensyn gjorde seg gjeldende, og at tvil om hvorvidt kildevernet skulle vike, skal falle ut til for fordel for kildevernet. På bakgrunn av interesseavveiningen og det brede vernet Den europeiske menneskerettsdomstol på grunnlag av Den europeiske menneskerettskonvensjons artikkel 10 har oppstilt for upublisert materiale som kan avsløre uidentifiserte kilder, var det ikke grunnlag for å la kildevernet vike. Det er grunn til å håpe at dette kildevernet også omfatter forskere og deres kilder. For førstevoterende dommer skriver:

(69) As [Rolfsens] filmprosjekt har som formål å avdekke hva som motiverer norske statsborgere til å bli Syriafarere og hvordan C og hans trosfeller i Profetens Ummah kommuniserer med trosfeller. A har gitt uttrykk for at filmen skal gi innsikt i terrororganisasjonen Den islamske staten og deres forsøk på å islamisere verden. Jeg nevner at filmprosjektet har økonomisk støtte fra Norsk Filminstitutt og Fritt Ord.

(70) Etter min vurdering er As filmprosjekt i kjernen av undersøkende journalistikk; det griper fatt i et sentralt og presserende samfunnsproblem hvor allmenheten og myndighetene har behov for kunnskap og innsikt. Undersøkelsene er gjort mulig fordi A har en særlig og tillitsbasert tilgang til et lukket islamistisk miljø. Jeg legger til grunn at et effektivt kildevern er helt avgjørende for at filmen kan realiseres. Så vidt jeg forstår, er også konsekvensen av politiets ransaking og beslag at kildene har trukket seg.

(71) På denne bakgrunn gjør det seg derfor gjeldende særlig sterke kildevernhensyn. Men også hensynet til etterforskningen i en så alvorlig sak veier tungt. Politiet har imidlertid en rekke etterforskningsmetoder til disposisjon i saker som dette, og det fremstår 
som uklart hvor nødvendige opplysningene i det beslaglagte filmmaterialet er for etterforskningen. Det er også et moment i helhetsvurderingen at Bs reise til Syria var avverget da ransakingen fant sted (Norges Høyesterett 2015).

Det er også klart at forskning på ekstremisme, med formål å avdekke hva som motiverer og ellers kan forklare hva som får personer til å ville gjennomføre ekstreme - og voldelige - handlinger, «griper fatt i et sentralt og presserende samfunnsproblem hvor allmenheten og myndighetene har behov for kunnskap og innsikt».

I et parallelt tilfelle kan altså jusen gi forskningsetisk veiledning, men det er ikke alltid informasjon man får, vil passe så godt inn i et slikt mønster. Dette innebærer at det uansett vil ligge forskningsetiske utfordringer her. Det fikk sosiologen Katrine Fangen erfare da hun gjorde feltarbeid blant rasister og nynazister i Oslo i begynnelsen av 1990-årene (Fangen 1998). Hun ble vitne til opptakten til voldshandlinger hvor særlig én episode var meget alvorlig. Det aktuelle høyreekstreme miljøet hadde hatt flere sammenstøt med Blitz-miljøet den siste tiden, og Fangen skjønte at de selv planla «noe»; hun merket at hun var mer uønsket i gruppen enn vanlig. Flere virket urolige, én hadde skutt i lufta med en hagle, én ravet rundt med en diger kjepp. Forskeren ble med da gruppen beveget seg mot Youngstorget, men der fikk hun klar beskjed: «nå er det vel best du drar hjem» (Ekern 2002). Dagen etter kunne hun lese i avisen at høyreekstremistene hadde angrepet Blitz, kastet molotovcocktails mot huset og skutt med hagle.

Hvor mye kan man si at Fangen visste? Burde hun advart Blitz eller uttrykt sin bekymring overfor politiet (PST)? Fangen har selv tematisert dette (Fangen 1998). Etter at hun selv hadde fortalt om denne episoden på et møte arrangert av SOS Rasisme, sendte Blitzmiljøet et brev til Den nasjonale forskningsetiske komité for samfunnsvitenskap og humaniora (NESH) med ønske om en vurdering 
av de etiske sidene ved den typen forskning. Blant annet problematiserte de hennes manglende anmeldelse av opptakten til angrepet og om dette kunne forsvares av hensyn til forskningen, eller om det ville være viktigere å bryte tillitsforholdet til miljøet hun fulgte, for å hindre tap av menneskeliv (Ekern 2002).

Den gang svarte NESH at de gir anbefalinger og råd, men ikke har myndighet til å være en dømmende instans. Komiteen viste til de retningslinjene de har utarbeidet, hvor det heter at «Forskeren må unngå å bli medskyldig i ulovligheter», og at det finnes en rettslig plikt til å avverge særlig alvorlige lovbrudd (Ekern 2002). Svaret kan tolkes som at NESH mente at Fangen burde bli anmeldt. Men flere uklarheter belyser at dette ikke var et svar uten forbehold. Hva ligger det i å være klar over at en forbrytelse skal bli begått? Det lå usikkerhet i situasjonen, og derfor var det også rom for tolkninger. Komiteens konklusjon den gang var at det ikke finnes noe fasitsvar på et slikt dilemma som Fangen ble satt i (Ekern 2002; se også Jipson og Litton 2000: 156f). Men at det er vanskelig å finne et entydig svar, begrenser ikke behovet for etisk refleksjon.

Det samme behovet for etisk refleksjon gjelder også om man får kunnskap om forbrytelser som allerede er begått. Selv om jusen ikke pålegger noen å bidra til oppklaring av slike forbrytelser, kan det oppfattes som en moralsk plikt, ikke minst av hensyn til ofre og pårørende. Det kan også ligge en mulighet til å forhindre gjentakelse i oppklaring og straffeforfølgelse av en allerede begått forbrytelse. Derfor må denne moralske plikten til også å anmelde allerede begåtte forbrytelser veies opp mot forskeres plikt til å beskytte og anonymisere kilder. Og forskerens plikt til å framskaffe kunnskap.

\section{Ideologi}

Verken ekstreme islamister eller høyreekstremister i Norge har en klar og konsistent ideologi. Dette illustreres av kompendiet til 
Anders Behring Breivik. Dette er et sammensurium av ideer og ideologiske brokker satt sammen på en løs og sprikende måte. Mange forskere forsøker å forstå ved å lese og tolke disse tekstene. Dette gjelder også meg selv og kolleger jeg har diskutert saken med, særlig under rettssaken. Slike samtaler og diskusjoner om tolkninger vil i neste omgang bli presentert i mediene og i faglige arbeider. Dette gjorde også de sakkyndige på ekstremisme og terrorisme i rettssaken mot Breivik i 2012. En slik prosess har også til hensikt å skape sammenheng og konsistens. Problemet oppstår når det i utgangspunktet ikke er en slik konsistens og sammenheng i de ideene man fokuserer på og vil forstå. For ved å levere mer konsistente tolkninger av teksten kan også forskere bidra til klargjøring av ekstremisten(e)s eget idéunivers.

Breiviks ideologiske «utvikling» fra publiseringen av kompendiet og terroren 22. juli $2011 \mathrm{og}$ til i dag kan illustrere dette. I kompendiet nedtoner Breivik kraftig sin tilhørighet til den nazistiske tradisjonen innenfor høyreekstremismen. Han er heller ikke eksplisitt antisemitt. Det er i og for seg ingen grunn til å tvile på at dette var Breiviks (uklare) posisjon da han satte sammen sitt kompendium. Under rettssaken blir hans nazistiske holdninger tydeligere, men likevel ikke eksplisitt uttrykt. Flere forskere som uttalte seg som sakkyndige vitner, poengterer likevel det nære slektskapet med nazistisk ideologi som er å finne i Breiviks kompendium og uttalelser i retten. Etter domfellelsen har Breivik så sendt ut en rekke ideologiske meldinger og rundskriv hvor han tilkjennegir at han er nasjonalsosialist. Han har «etablert» et fascistisk parti, og han bekjenner seg til Vidkun Quisling som en forløper (Breivik 2014). Det kan ikke sies sikkert uten nærmere undersøkelser (eventuelt intervjuer), men det er grunn til å tro at Breivik har blitt påvirket av forskernes tydeliggjøring av hans ideologi og den ideologiske tradisjonen han står i, blant annet fordi noen av forskernes formuleringer av hans ideologi kan 
spores i hans senere uttalelser. Slik kan forskerne ha bidratt til en avklaring av hans egen posisjon og dermed til utviklingen av hans ekstreme ideologi. Seniorforsker Terje Emberland, et av de sakkyndige vitnene i rettssaken, sier det slik i et foredrag, etter å ha undersøkt Breiviks ideologiske utvikling etter publiseringen av kompendiet: «It is obviously a chilling and ethically challenging fact that I, along with the other expert-witnesses, apparently have contributed in shaping his cut-and-paste ideas into a more coherent whole. In his cell the real Breivik has fed on this ideal type Breivik» (Emberland 2015). Lignende tanker har Mattias Gardell gjort seg, både etter å ha intervjuet Aryan Nations-medlemmer i amerikanske fengsler (Gardell 2003), for ved gjenbesøk har han opplevd å få sin framstilling av deres ideologi reprodusert, og etter å ha vært sakkyndig i Breivik-saken (personlige meddelelser).

Men ikke bare kan forskere komme til å bidra til avklaringer og tydeliggjøring av ideologiske posisjoner, de kan også bidra til spredning av de ideologiske posisjonene. Ved at de presenterer og formidler sine funn og analyser i fagartikler og andre studier, gir de også ideologien spredning, om enn i kritisk utgave. Det vil likevel være mulig for den studerte ekstremisten, in casu Breivik, eller andre og sympatiserende ekstremister å forholde seg til ideologien som sådan.

Beslektet med temaet ideologiavklaring, er at seriøs forskning på ekstreme personer, grupper og ideologier også kan bidra til å legitimere deres ekstremisme (Gabriel 2000), men dette skal ikke utdypes her.

\section{Utvikling av voldsstrategier}

Vi trenger kunnskapen for å kunne forebygge, men forskere kan dermed også bidra til å raffinere ekstremisters og terroristers metoder og strategier. Det er kjent at bøker og fagartikler om Al Qaida 
ble funnet i Osama bin Ladens bokhylle i Abbottabad (Office of the Director of National Intelligence n.d. [2015]). I de tidsskriftene som ble funnet, har også norske forskere publisert studier av den moderne salafi-jihadismen, Al Qaida og andre islamistiske grupper. Innsikter fra slike studier kan ha blitt inkorporert i Al Qaidas tenkning og strategier slik at man for eksempel vil kunne unngå eller omgå sikkerhetsforanstaltninger, sikre større voldseffekt og/eller mediegjennomslag, og dermed mer effektiv opinionspåvirkning, uten at vi kan si dette sikkert uten nærmere analyser. Men i dag er det all grunn til å tro at Den islamske staten (IS) har betydelig kompetanse, i form av tidligere etterretningsoffiserer fra Saddam Hussains regime, til å analysere faglige studier av IS' ideologi, strategi, taktikk, rekrutteringspraksis, mediestrategi og så videre. Dette vil gjøre det mulig å motvirke, eller i alle fall svekke effekten av, de tiltak som ulike lands myndigheter iverksetter i kampen mot ekstremisme og terrorisme.

\section{Konklusjoner}

Med så mange forskningsetiske dilemmaer, inkludert mulighetene for å bidra til ekstremister og terroristers ideologiske, strategiske og taktiske utvikling og gjennomføringsevne, kan man lure på om det i det hele tatt er forsvarlig å studere - og publisere om ekstremisme og terrorisme. Når svaret likevel er et klart ja, er det fordi slik forskning uansett vil og må bli gjennomført av ulike lands politi- og etterretningstjenester. Slike studier vil ofte være gradert og unndratt seriøse fagfellevurderinger. Dette innebærer at viktige beslutningstakere og opinionen ikke får innsikt i det grunnlaget som politiet og etterretningstjenestene har for sine handlinger. Ved at det ikke finnes åpen og tilgjengelig forskning om temaet, vil det heller ikke være mulig å vurdere om de aktuelle myndighetene handler på et holdbart grunnlag, og om deres virkemidler er sakssvarende. 
Dette innebærer helt generelt at både det spesifikke kontraekstremisme- og kontraterrorbehovet og det generelle samfunnsbehovet for kunnskap må veies opp mot problemene med slik forskning. Selv om det finnes dilemmaer, er konklusjonen at fordelene med forskningen er større enn ulempene. Det er viktig med solide kunnskaper for å kunne forebygge, avverge og begrense voldelig ekstremisme og terrorisme. Like viktig er det at denne kunnskapen er tilgjengelig for allmennheten i åpne, demokratiske samfunn. For det er allmennheten som til slutt er ansvarlig for den politikken som føres i våre demokratier. Forskeres etiske ansvar for å bidra til en opplyst allmennhet er således meget tungtveiende.

\section{Annen anbefalt litteratur}

Den norske og internasjonale forskningslitteraturen om forskningsetikk er stor og godt kjent. Forskningsetiske utfordringer knyttet til ekstremismeforskningen kan sies å bli indirekte berørt i denne litteraturen. En del arbeider fokuserer også eksplisitt på utfordringene knyttet til ulike former for ekstremisme, særlig terrorisme. For en bredere oversikt over mer av den relevante litteraturen, se bibliografiene i Bikson mfl. 2007, Falcone 2010 og Reding mfl. 2014.

\section{Referanser}

Bakker, E. (2006). Jihadi Terrorists in Europe. Den Haag: Netherlands Institute of International Relations/Clingendael.

Bergo, I.G. (2015). «FFI: Tør ikke forske på fremmedkrigere», vg.no, 13.08.2015, http://www.vg.no/nyheter/innenriks/ffi-toer-ikke-forskepaa-fremmedkrigere/a/23500676/ (nedlastet 21.10.15)

Bikson, T.K., Bluthenthal R.N., Eden R. \& Gunn P.P. (Red.) (2007). Ethical Principles in Social-Behavioral Research on Terrorism. Probing the Parameters. Workshop proceedings, prepared for the National Science Foundation and the Department of Justice, RAND. 
Borchgrevink, A.S. (2012). En norsk tragedie. Anders Behring Breivik og veiene til Utøya. Oslo: Gyldendal.

Breivik, A.B. (2014), skriv av 08.10.2014.

Buchanan, E. A. \& Zimmer, M. (2012), Internet Research Ethics. The Stanford Encyclopedia of Philosophy (Spring 2016 Edition). http:// plato.stanford.edu/archives/spr2016/entries/ethics-internet-research/ (nedlastet 16.06.16).

Christ, G. (2010). Social work contribution to a comprehensive model of mourning: the experience of bereaved families of fire-fighters killed on 9/11/01. Progress in Palliative Care: Science and the Art of Caring, 18 (4), 228-236.

Christensen, M. (2013). Moren. Historien om Wenche Behring Breivik. Oslo: Achehoug.

De nasjonale forskningsetiske komiteene (2006). Forskningsetiske retningslinjer for samfunnsvitenskap, humaniora, juss og teologi. https://www.etikkom.no/forskningsetiske-retningslinjer/ Samfunnsvitenskap-jus-og-humaniora/

De nasjonale forskningsetiske komiteene (2014). Frukostseminar: forsking på høgreekstremisme etter 22. juli. https://www.etikkom.no/Aktuelt/ Nyheter/2014/Frukostseminar-forsking-pa-hogreekstremisme-etter22-juli/ (21.02.14; nedlastet 31.01.16).

Ekern, L. (2002). Et «Fangens dilemma». Forskningsetikk, nr. 4, s. 15. Emberland, T. (2015). The SS Phantasies of Anders Behring Breivik. Foredrag under konferansen «Never Again 22 July?», Utøya, 18.10.2015.

Falcone, J. M. (2010). «I spy...': The (Im)possibilities of Ethical Participant Observation with Antagonists, Religious Extremists, and Other Tough Nuts», Michigan Discussions in Anthropology, 18 (1), 243-282. http://quod.lib.umich.edu/cgi/p/pod/dod-idx/i-spy-theimpossibilities-of-ethical-participant-observation.pdf? $\mathrm{c}=$ mdia;idno= 0522508.0018.108

Fangen, K. (1998). Fangens dilemma. Nytt Norsk Tidsskrift, 15 (3), 257-269.

Fossheim, H. \& Ingierd, H. (Red.) (2013). Forskerens taushetsplikt og meldeplikt, Oslo: De nasjonale forskningsetiske komiteene. https://www.etikkom.no/Aktuelt/publikasjoner/ Forskeres-taushetsplikt-og-meldeplikt/ 
Gabriel, J. (2000). Whiteness. Endangered knowledge, endangered species? I: Lee-Treweek, G. \& Linkogle S. (Red.) Danger in the field. Risk and ethics in social research. London: Routledge.

Gardell, M. (2003). Gods of the Blood: The Pagan Revival and White Separatism. Durham, NC: Duke University Press.

Hemmingsen, A.-S. (2011). Salafi Jihadism: Relying on fieldwork to study unorganized and clandestine phenomena. Ethnic and Racial Studies, 34 (7), 1201-1215. DOI: 10.1080/01429870.2011.5686.28.

Jones, E. \& Bhui, K. (2008). The new ethics of research into terrorism. BMJ, 337:a3069 DOI: http://dx.doi.org/10.1136/bmj.a3069.

Jipson, A.J. \& Litton, C.E. (2000). Body, Career and Community. The implications of researching dangerous groups. I Lee-Treweek, G. \& Linkogle S. (Red.) Danger in the field. Risk and ethics in social research. London: Routledge.

Lee-Treweek, G. \& Linkogle S. (Red.) Danger in the field. Risk and ethics in social research. London: Routledge.

Norges Høyesterett (2015), HR-2015-2308-A, lovdata.no, https:// lovdata.no/dokument/HRSTR/avgjorelse/hr-2015-2308-a (nedlastet 27.11.15).

Office of the Director of National Intelligence (2015). Bin Laden's Bookshelf. http://www.dni.gov/index.php/resources/bin-ladenbookshelf (nedlastet 31.01.16).

Reding, A., van Gorp A., Robertson, K, Walczak, A., Giacomontonio, C \& Hoorens, S. (2014). Handling ethical problems in counterterrorism. An inventory of methods to support ethical decisionmaking. Prepared for the Research and Documentation Centre on behalf of the National Coordinator for Counterterrorism and Security at the Netherlands Ministry of Security and Justice, RAND Europe.

Sageman, M. (2004). Understanding Terror Networks. Philadelphia: University of Pennsylvania Press.

Severinsen, J. (2014). Forskere vil intervjue Behring Breivik. https://www. etikkom.no/Aktuelt/Nyheter/2014/Forskere-vil-intervjue-BehringBreivik/ (25.04.14; nedlastet 31.01.16).

Skilbrei, M.-L. (2013). Hva betyr taushet? Taushetsplikten og varslingsplikten i vanskelig farvann. I: Fossheim, H. \& Ingierd, H. (Red.) Forskerens taushetsplikt og meldeplikt. Oslo: De nasjonale forskningsetiske komiteene. 
Speckhard, A. (2009). Research Challenges Involved in Field Research and Interviews Regarding the Militant Jihad, Extremism, and Suicide Terrorism. Democracy and Security, 5:3, 199-222. DOI: 10.1080/17419160903183409.

Store norske leksikon og John Christian Elden (2015). «Avvergelsesplikt», snl.no, https://snl.no/avvergelsesplikt (nedlastet 27.11.15).

Stovall-McClough, K. C. \& Cloitre, M. (2006). Traumatic Reactions to Terrorism: The Individual and Collective Experience. I Schein L., Spitz, H.I., Burlingame, G.M. og Muskin P.R. (Red.). Psychological Effects of Catastrophic Disasters: Group Approaches to Treatment, Binghamton, NY: Haworth Press.

Thon, B.E. (2015). Forsk på fremmedkrigere! Dagbladet, 07.08.2015 http:// www.dagbladet.no/2015/08/07/kultur/meninger/fremmedarbeidere/ debatt/kronikk/40498969/ (nedlastet 25.02.16).

von Hippel, W. (2015). Ethically questionable research. I: Sternberg R.J. \& Fiske, S.T. (red.). Ethical challenges in the behavioral and brain sciences: case studies and commentaries (155-156) New York, NY: Cambridge University Press. DOI:10.1017/CBO9781139626491.059 


\section{Bidragsytere}

Grete Dyb er utdannet barnepsykiater og er ansatt som seniorforsker ved Nasjonalt kunnskapssenter om vold og traumatisk stress (NKVTS) og som førsteamanuensis ved Det medisinske fakultet ved Universitetet i Oslo. Hun har doktorgrad om posttraumatiske stressreaksjoner hos barn og ungdom og har siden 2004 ledet en rekke prosjekter om barn utsatt for overgrep, vold og katastrofer. Siden 2011 har hun ledet Utøya-studien ved NKVTS. (https:// www.nkvts.no/ansatt/grete-dyb/)

Kari Dyregrov er forskningsleder ved Senter for Krisepsykologi, Bergen, og professor i $20 \%$ stilling ved Høgskolen i Bergen. Hun er dr.philos. med sosiologi, psykologi og fysioterapi i fagkretsen. Hennes forskningsfelt er konsekvenser, hjelpebehov, mestring og hjelpetiltak etter kriser og katastrofer, og også kommuners hjelpetilbud til kriserammede. Dyregrov har utgitt en rekke bøker, bokkapitler og vitenskapelige og populærvitenskapelige artikler.

Ragnar Eikeland er bosatt på Valestrandsfossen på Osterøy, som er Norges største innlands-øy og ligger like nordøst for Bergen. Eikeland er fabrikksjef på et røykeri av ørret og laks i Valestrand med ca. 150 ansatte. Eikeland er gift og har 2 sønner der den yngste, som da var 21 år, ble revet bort under tragedien på Utøya 22. juli 2011. Begge sønnene hadde fotball og politikk som hovedinteresser og den eldste, som nå er 32 år, driver fortsatt med 
politikk. Han er gift og har fått to barn. Tragedien på Utøya i 2011 har selvfølgelig preget, og preger, livet til familien Eikeland. Men de to flotte barnebarna har hjulpet dem i hverdagen med å rette fokus bort fra tragedien.

Vidar Enebakk har hovedfag idéhistorie og doktorgrad i vitenskapsteori og vitenskapsstudier fra Senter for teknologi, innovasjon og kultur (TIK) og har tidligere arbeidet som forsker ved Forum for universitetshistorie (FFU) ved Universitetet i Oslo. Han er nå sekretariatsleder i Den nasjonale forskningsetiske komité for samfunnsvitenskap og humaniora (NESH).

Tor Einar Fagerland er leder og førsteamanuensis ved Institutt for historiske studier ved NTNU. Fagerland er leder for forskningsprosjektet «July 22 and the Negotiation of Memory» og var i 2015, sammen med arkitekt Atle Aas, ansvarlig for etableringen av 22. juli-senteret i regjeringskvartalet. I 2016 har han sammen med Aas hatt ansvar for innholdet i det nye læringssenteret på Utøya.

Kristin Alve Glad er utdannet psykolog fra Universitetet i Oslo. Hun har også en Bachelor of Arts (psykologi) fra Trinity College Dublin. Glad har vært tilknyttet Nasjonalt kunnskapssenter om vold og traumatisk stress (NKVTS) siden 2005 og har publisert rapporter og fagartikler om blant annet tsunamikatastrofen, traumefokusert kognitiv atferdsterapi og terroranslaget på Utøya. Hun har bidratt i planleggingen av og datainnsamlingen på Utøya-prosjektet, og er nå ansatt som stipendiat på dette prosjektet.

Lars Gule er førsteamanuensis ved Institutt for internasjonale studier og tolkeutdanning, Høgskolen i Oslo og Akershus. Han har studert historie, filosofi og samfunnskunnskap ved 
Universitetet i Bergen og avla doktorgraden samme sted i 2003. Forskingsinteressene har vært Midtøsten, menneskerettigheter og islamsk politisk tenkning. Etter 22. juli 2011 ble hans erfaringer med debatt med ekstremister på internett et forskningstema og han har forsøkt å utarbeide mer presise ekstremisme-definisjoner. Fokuset i dag er på islamistisk ekstremisme. Ved HiOA underviser han også om ekstremisme og ekstremiseringsprosesser.

Gertrud Sofie Hafstad er utdannet psykolog fra Universitetet i Bergen, og er ansatt som forsker ved NKVTS. Hun har tidligere jobbet i psykisk helsevern for barn og unge, og har en doktorgrad om barn og unge som overlevde tsunamien i Sør-øst Asia. Hun har skrevet en rekke artikler og bokkapitler som omhandler barn og unges reaksjoner etter traumatiske hendelser. Siden 2014 har hun vært nestleder for Utøya-studien ved NKVTS.

Helene Ingierd er sekretariatsleder for Den nasjonale forskningsetiske komité for naturvitenskap og teknologi. Ingierd har en ph.d. i statsvitenskap fra Universitetet i Oslo, og har tidligere jobbet med krigens etikk.

Annika Melinder er professor i psykologi og spesialist i klinisk psykologi, og har siden 2007 ledet en større forskningsgruppe, enheten for kognitiv utviklingspsykologi (EKUP) ved Universitet i Oslo (http://www.sv.uio.no/psi/forskning/grupper/ekup/index. html). Hun er spesialist i klinisk psykologi og hennes forskning omfatter både typisk utviklede barn og unge, i tillegg til sårbare og kliniske grupper barn og unge. Forskningstemaene hennes strekker seg fra basale problemstillinger knyttet til nevrokognisjon til anvendte felt som retts- og vitnepsyklogi. Melinder har utstrakt erfaring med søknader til REK, NSD, Riksadvokaten og til rådet for taushetsplikt og forskning. 
Anne Marita Milde er førsteamanuensis i biologisk og medisinsk psykologi og har ledet forskningsgruppen om eksperimentell og klinisk stress og søvn, Universitetet i Bergen (Resource group on Experimental and Clinical Stress and Sleep RECSS) fra 2007 til 2015 (http://www.uib.no/en/rg/recs\#). Hun er spesialist i klinisk psykologi, har vært tilknyttet Ressurssenter om vold, traumatisk stress og selvmordsforebygging (RVTS Vest) siden 2006 og har kompetanse innen basal og anvendt stress- og traumepsykologi. Fra september 2016 fungerer hun som leder for Regionalt kunnskapssenter for barn og unge (RKBU Vest - UNI Research). (http:// uni.no/nb/uni-helse/om-rkbu-vest/).

Nils Olav Refsdal er statsviter og har siden 2012 koordinert forskningen der de som ble berørt av terrorangrepet 22. juli 2011 deltar, først i sekretariatet til De nasjonale forskningsetiske komiteene, og siden i Helsedirektoratet, da koordineringsfunksjonen ble flyttet dit. 